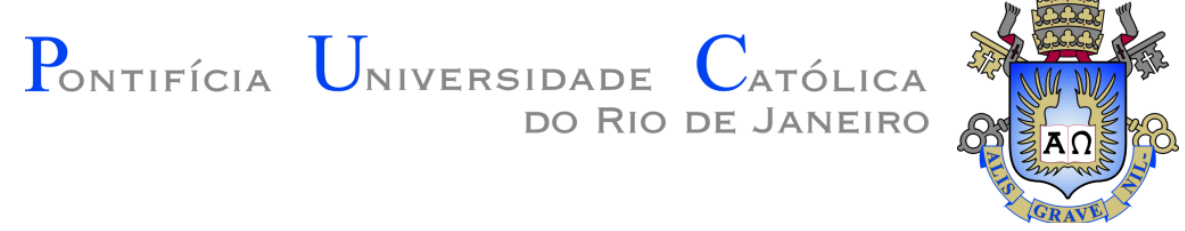

Carolina Paixão de Albuquerque Pinheiro

Os ataques ao enquadre nos casos-limite enquanto tentativas de passagem para 0 campo do uso do objeto

Dissertação de Mestrado

Dissertação apresentada como requisito parcial para obtenção do grau de Mestre pelo Programa de PósGraduação em Psicologia Clínica do Departamento de Psicologia do Centro de Teologia e Ciências Humanas da PUC-Rio.

Orientadora: Profa ${ }^{a}$. Claudia Amorim Garcia

Rio de Janeiro

Abril de 2013 
Carolina Paixão de Albuquerque Pinheiro

\section{Os ataques ao enquadre nos casos-limite enquanto tentativas de passagem para 0 campo do uso do objeto}

Dissertação apresentada como requisito parcial para obtenção do grau de Mestre pelo Programa de Pós-Graduação em Psicologia Clínica do Departamento de Psicologia do Centro de Teologia e Ciências Humanas da PUC-Rio. Aprovada pela Comissão Examinadora a baixo assinada.

Profa. Claudia Amorim Garcia Orientadora Departamento de Psicologia - PUC-Rio

Prof. Carlos Augusto Peixoto Departamento de Psicologia- PUC-Rio

Profa. Ana Lila Lejarraga Departamento de Psicologia Clínica - UFRJ

Profa. Denise Berruezo Portinari Coordenadora Setorial de Pós-Graduação

e Pesquisa do Centro de Teologia e Ciências Humanas - PUC-Rio 
Todos os direitos reservados. É proibida a reprodução total ou parcial do trabalho sem autorização da autora, da orientadora e da universidade.

\section{Carolina Paixão de Albuquerque Pinheiro}

Graduou-se em Psicologia na PUC-Rio em 2008. Especializou-se em Clínica Psicanalítica no IPUB/UFRJ em 2011. Atualmente, atua como psicóloga clínica na ONG Casa da Árvore, no Instituto de Estudos da Complexidade e atende em consultório particular.

Ficha catalográfica

Pinheiro, Carolina Paixão de Albuquerque

Os ataques ao enquadre nos casos-limite enquanto tentativas de passagem para o campo do uso do objeto / Carolina Paixão de Albuquerque Pinheiro ; orientadora: Claudia Amorim Garcia. 2013.

155 f. ; $30 \mathrm{~cm}$

Dissertação (mestrado)-Pontifícia Universidade Católica do Rio de Janeiro, Departamento de Psicologia, 2013.

Inclui bibliografia

1. Psicologia - Teses. 2. Ataques ao enquadre. 3. Setting. 4. Casos-limite. 5. Trabalho do negativo. 6. Agressividade. 7. Uso do objeto. I. Garcia, Claudia Amorim. II. Pontifícia Universidade Católica do Rio de Janeiro. Departamento de Psicologia. III. Título.

CDD: 150 


\section{Agradecimentos}

Aos meus pais, pelo amor maior e pelo incentivo de sempre. Por estarem ao meu lado em todas as minhas escolhas profissionais.

À minha orientadora Claudia Amorim Garcia, por toda a dedicação na transmissão da teoria e pela leitura atenta desde a monografia da graduação. Por deixar eu lhe convencer, mais uma vez, do meu projeto de trabalho.

Ao professor Carlos Augusto Peixoto Junior, por atentar-me cada vez mais para as sutilezas presentes na obra de Winnicott, este autor que ousa nos falar sobre alegria.

À professora e supervisora Ana Lila Lejarraga, pela escuta sensível em supervisão e pelo interesse e generosidade em participar novamente de uma apresentação acadêmica minha.

À professora Lidia Levy, por todo o aprendizado no estágio docência.

A todos do nosso grupo de pesquisa, pelas riquíssimas discussões em torno da teoria e da clínica contemporâneas.

Aos meus pacientes, com quem aprendo infinitamente, sem os quais a teoria não faria sentido.

Aos amigos da Casa da Árvore e do Instituto de Estudos da Complexidade, com quem eu tenho o prazer e o privilégio de dividir, além das reflexões clínicas da maior qualidade, grandes amizades.

Ao Zé Otávio, mais uma vez, pela terra.

À CAPES e à PUC-Rio, pelos auxílios concedidos. 


\section{Resumo}

Pinheiro, Carolina Paixão de Albuquerque; Garcia, Claudia Amorim. Os ataques ao enquadre nos casos-limite enquanto tentativas de passagem para o campo do uso do objeto. Rio de Janeiro, 2013. 155p. Dissertação de Mestrado - Departamento de Psicologia da Pontifícia Universidade Católica do Rio de Janeiro.

A dissertação consiste numa pesquisa teórica que propõe o argumento de os ataques ao enquadre, frequentemente empreendidos pelos casos-limite, constituírem a tentativa clínica de passagem para o campo do uso do objeto. A agressividade não bem manejada pelo ambiente prejudica o reconhecimento da externalidade, resultando numa tendência à destruição que se torna característica central da clínica com estes casos. O trabalho do negativo malsucedido impossibilita a construção do espaço da ausência no psiquismo, fundamental à construção de representações, à instauração das fronteiras intrapsíquicas e intersubjetivas e ao investimento em objetos substitutos. Os prejuízos relativos à agressividade e ao trabalho do negativo redundam na precariedade das fronteiras entre o eu e o outro, sugerindo a prevalência de uma relação pautada na vertente subjetiva do objeto, logo não reconhecido em sua natureza externa. As contribuições de Winnicott e Green fundamentam nossa hipótese de que a destrutividade - expressa na clínica dos casos-limite através dos ataques ao enquadre - consiste numa tentativa atuada de passagem para o campo do uso do objeto, que consolida a unidade do self ao mesmo tempo que possibilita o reconhecimento do objeto na realidade compartilhada.

\section{Palavras-chave}

Ataques ao enquadre; setting; casos-limite; trabalho do negativo; agressividade; uso do objeto. 


\section{Abstract}

Pinheiro, Carolina Paixão de Albuquerque; Garcia, Claudia Amorim (Advisor). The attacks on the setting in borderline patients as a way to reach the use of an object. Rio de Janeiro, 2013. 155p. Masters Dissertation - Departamento de Psicologia da Pontifícia Universidade Católica do Rio de Janeiro.

The dissertation consists of theoretical research proposing the argument that the attacks on the setting, often undertaken by borderline patients, consists on a clinical way of reaching the use of an object. The aggressiveness not well handled by the environment affects the recognition of the externality, resulting in a tendency towards destruction which becomes the central feature in the borderline clinic. The unsuccessful work of the negative precludes the construction of an absence space in the psyche, fundamental to the construction of representations, the introduction of intrapsychic and intersubjective borders, as the investment in substitute objects. Losses related to aggressiveness and the work of the negative result in precarious boundaries between self and other, suggesting the prevalence of a relationship based in the subjective aspect of the object, not just recognized in his external nature. The contributions of Winnicott and Green underlie our hypothesis that the destructiveness - expressed in borderline clinic through the attacks on the setting - consists in an actuated way to reach the use of the object, which consolidates the unity of self while enables the recognition of the object in shared reality.

\section{Keywords}

Attacks on the setting; borderline patients; work of the negative; agressivity; use of an object. 


\section{Sumário}

1 - Introdução 9

2 - Winnicott e o percurso até a conquista do uso do objeto. .21

2.1 - Primeiras delimitações eu/não-eu: integração, personalização e realização...23

2.2 - Dentro e fora ou nem dentro, nem fora: o paradoxo da transicionalidade.....29

2.3 - O papel da agressividade na construção da externalidade.............................35

2.4 - O uso do objeto e o relacionamento entre pessoas totais...............................41

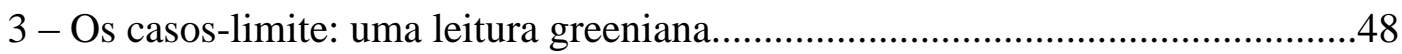

3.1 - Breve arqueologia dos casos-limite.....................................................49

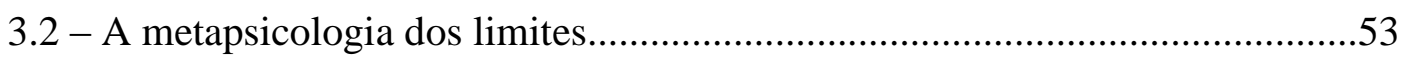

3.3 - As vicissitudes do objeto e o trabalho do negativo......................................60

4 - O enquadre analítico: principais contribuiç̧̃ões...............................................75

4.1 - As primeiras delimitações do fazer psicanalítico: o enquadre em Freud........78

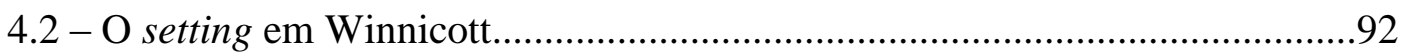

4.3 - A situação analítica como campo dinâmico e a psicanálise do enquadramento psicanalítico.

5 - Os ataques ao enquadre e o uso do objeto na clínica dos casos-limite. 115

5.1 - A clínica dos casos-limite: aspectos transferenciais 116

5.2 - $\mathrm{O}$ enquadre que não se deixa esquecer: os ataques enquanto tentativas de passagem para o campo do uso do objeto

6 - Considerações finais

7 - Referências bibliográficas 
É pertinente indagar neste ponto: qual foi o estado que veio antes do uso, antes de o analisando usar o analista? É possivel descrever não somente a libélula, mas também o processo de metamorfose $e$, em verdade, a própria crisálida? Isso verdadeiramente seria bom. 


\section{Introdução}

Na clínica psicanalítica contemporânea, frequentemente nos deparamos com organizações sintomáticas e fenômenos transferenciais que questionam a aplicabilidade do método analítico tal como formulado por Freud (1904) quando do abandono da hipnose, no fim do século XIX. Tendo como premissas básicas a associação livre do paciente e a escuta flutuante e interpretação do analista, o método psicanalítico encontra limitações consideráveis no atendimento de pacientes cuja capacidade representacional se mostra prejudicada em função de experiências de ordem traumática de difícil elaboração. Nos casos-limite, pacientes limítrofes ou borderline ${ }^{1}$, paradigmáticos da clínica contemporânea (Urribarri, 2010), a dificuldade representacional alia-se a uma destrutividade que adquire característica central no tratamento (Winnicott, 1969 [1968]; Green, 2002), esteja ela dirigida aos processos de pensamento - impedindo as ligações, no campo intrapsíquico - ou ao vínculo transferencial - no âmbito intersubjetivo , intensificando os limites da analisabilidade (Green, 1988 [1975]) comumente referidos à clínica com estes casos.

As dificuldades representacionais que impedem o curso da associação livre nos casos-limite, bem como a instauração de uma transferência com modalidades distintas da neurose de transferência tradicionalmente estabelecida no tratamento padrão impossibilitam uma análise guiada pelo método habitual, fazendo com que o analista tenha de recorrer a técnicas diversas tais como o holding clínico e a sobrevivência analítica estipuladas por Winnicott (1955-56; 1969 [1968]) quando da impossibilidade de interpretação. As manifestações destrutivas que recaem sobre a situação analítica em sua complexidade - que envolve as demarcações de base do enquadre, o método analítico e a própria pessoa do analista - são compreendidas em termos de "ataques ao enquadre" (Green, 2010 [1988]; André, 1999; Figueiredo, 2003b; Garcia, 2010 [2007]; Damous, 2012a; 2012b), frequentemente empreendidos pelos casos-limite no encontro com os limites da situação analítica que refletem, por sua vez, a dinâmica estabelecida com os

\footnotetext{
${ }^{1}$ Não priorizaremos uma nomenclatura específica para estes casos, compreendendo casos-limite, borderline ou paciente limítrofe como equivalentes, dentro de um modo particular de constituição subjetiva.
} 
próprios limites do $e u$, igualmente atacados porque não devidamente investidos pulsionalmente pelo objeto primário (Figueiredo, 2003a).

O próprio enquadramento, metáfora do ego nesse sentido, é atacado em seus limites. O paciente borderline, pouco respeitoso quanto aos bons velhos hábitos, faz ressaltar a arbitrariedade do número de sessões, de sua duração e de sua maneira de desenrolar-se - e especialmente do fato de saber a quem cabe dizer que "está na hora". A arrumação e a manutenção de um enquadramento confiável e estável vêm confundir-se com a dinâmica do próprio tratamento. (André, 1999 : 74)

As dificuldades na técnica interpretativa, todavia, se fazem sentir desde os tempos de Freud, sobretudo no encontro com as neuroses traumáticas, em que a compulsão à repetição veiculada pela pulsão de morte (Freud, 1920) atesta o fracasso da simbolização em função do caráter irrepresentável dos conteúdos traumáticos. Na clínica, o que se vê são resistências de caráter intransponível que tornam certas análises quase ou definitivamente irrealizáveis, pois, se o objetivo analítico consiste, basicamente, em superar as resistências e tornar consciente o inconsciente - trazendo à tona a representação recalcada (Freud, 1904) -, a tarefa da rememoração torna-se praticamente inalcançável junto a estes pacientes, nomeados por Freud de "não-neuróticos" (Freud, 1920, p.147).

O método analítico, segundo Freud (1916-17), é eficaz somente nos casos de neurose, ficando as psicoses fora do âmbito de seu alcance. Para que o método possa ser posto em prática, todavia, são necessárias certas condições de base que configuram o enquadre ou o não-processo sobre o qual poderá se desenvolver o processo (Bleger, 1967) impulsionado pela dinâmica transferencial. Neste sentido, o enquadre abrange as delimitações do contrato analítico em termos de tempo, espaço, dinheiro, número de sessões, entre outros, instituindo assimetricamente os lugares e funções de paciente e analista e reduzindo toda a comunicação ao campo da palavra (Freud, 1904; 1905 [1904]; 1912a; 1913). Tais demarcações devem permanecer constantes a fim de que o foco se dirija às produções psíquicas passíveis de interpretação, já que veiculadas pela transferência enquanto uma reedição de relações significativas do passado do paciente para com a pessoa do analista (Freud, 1912b).

Se, em Freud, não foi possível empreender uma análise das psicoses e distúrbios afins, os desafios desta clínica e sua teorização ficaram a cargo de 
autores pós-freudianos tais como Ferenczi, Klein, Lacan e Winnicott, ressoando importantes contribuições para a condução da clínica atual. No presente trabalho, priorizaremos a contribuição de Winnicott $(1945 ; 1960 a ; 1962 ; 1963 a)$ acerca dos primórdios da constituição subjetiva, bem como a técnica analítica por ele empreendida através de uma nova concepção do setting ${ }^{2}$, estendendo assim o conceito de situação analítica para a análise dos casos que não puderam contar com um ambiente suficientemente bom nos primórdios da vida psíquica (Winnicott, 1954; 1955-56; 1959-64).

É a partir da observação direta de crianças e bebês e da clínica com pacientes psicóticos e borderline, sobretudo, que Winnicott concebe sua teoria do desenvolvimento emocional primitivo (Winnicott, 1945), partindo dos momentos mais iniciais de indiferenciação do bebê com o ambiente. A princípio, o infans encontra-se num estado de fusão com a mãe, ainda não percebida como um objeto externo e distinto dele próprio. Figura, neste estágio, uma dependência absoluta (Winnicott, 1963a) para com a mãe que, na melhor das hipóteses, desenvolve um estado temporário de extrema devoção e total sintonia com o bebê, a que Winnicott (1956) chamou de preocupação materna primária. A adaptação da mãe às necessidades do bebê neste estágio instaura um ambiente suficientemente bom (Winnicott, 1956) capaz de impulsionar as tendências inatas ao desenvolvimento, facilitando os processos maturacionais de integração, personalização e realização (Winnicott, 1945) dentro de um viver criativo.

No estado de fusão primordial, o holding (Winnicott, 1960a) enquanto o conjunto dos cuidados maternos confere ao bebê a experiência da ilusão de onipotência (Winnicott, 1962), que consiste em conceber o seio como uma criação sua, sendo parte de seu próprio corpo. Isto porque a provisão ambiental adequada - que envolve o segurar físico, o manuseio corporal, a empatia e a sensibilidade maternas - age de modo sincrônico com as necessidades do bebê, logo o seio é oferecido no momento exato em que a fome é sentida. Assim, o bebê se relaciona, inicialmente, com um objeto subjetivamente concebido (Winnicott, 1969 [1968]) que gradualmente poderá ser reconhecido em sua externalidade, a menos que o ambiente apresente condições adversas capazes de colocar em questão o

\footnotetext{
${ }^{2}$ Não será feita uma distinção entre os termos enquadre/ setting/ enquadramento/ contexto ou situação analítica, porém serão utilizados, preferencialmente, de acordo com a escolha terminológica de cada autor.
} 
reconhecimento do caráter independente da realidade/ objeto, e correlativamente a própria identidade e unidade egoica. Em condições favoráveis, a desadaptação gradual da mãe permite que o bebê comece a discernir entre o que é parte de sua imaginação e o que provém de um mundo não controlado por ele, dando início à delimitação das fronteiras entre o dentro e o fora, o eu e o não-eu, chegando ao reconhecimento do objeto objetivamente percebido (Winnicott, 1969 [1968]).

No caminho rumo à diferenciação interno/externo, a agressividade (Winnicott, 1939; 1950-55) e os fenômenos transicionais (Winnicott, 1971a) adquirem papel de suma importância, por proporcionarem, respectivamente, o caráter de realidade às experiências vividas, através do contato motor com o que é da ordem do não-eu; e a separação eu-objeto de forma progressiva e nãotraumática, com o auxílio de uma “primeira possessão não-eu” (Winnicott, 1971a, p.13).

Os fenômenos ou objetos transicionais estão inseridos numa terceira área de experiência que comporta o paradoxo da coexistência de elementos subjetivos e objetivos, em que o objeto é, ao mesmo tempo, criado pelo bebê, mas também encontrado na realidade externa (Winnicott, 1971a). Com a desadaptação gradual da mãe, nos momentos de sua ausência o bebê utiliza os objetos transicionais de forma a representá-la, e deste modo a simbolização tem início com a instauração desta área intermediária ou espaço potencial, fundamental à relacionabilidade com o mundo externo.

No que diz respeito à agressividade, é em termos de atividade e motilidade enquanto expressões da agressividade primária que as esferas do não-eu são a princípio alcançadas, no encontro com a oposição do ambiente que efetua uma espécie de resistência contra a qual os movimentos do bebê se chocam. A oposição do ambiente confere, deste modo, o caráter de realidade às experiências, sobretudo pela receptividade dos aspectos motores e sensoriais que consistem, a princípio, em exploração e descoberta do mundo. A oralidade é também parte da agressividade primária, a princípio impiedosa, já que o bebê ainda não possui meios de considerar o objeto em sua externalidade e demonstrar concernimento por seus atos. A ausência de concernimento é, no entanto, fundamental à capacidade futura de se relacionar com pessoas totais, sendo necessário, para tal, que o ambiente suporte os ataques imaginários que acompanham o sugar o seio 
nos momentos excitados, acrescentando aí as mordidas reais inerentes ao ato de mamar (Winnicott, 1950-55).

Deste modo, é somente num ambiente suficientemente bom que a agressividade possui meios de se expressar e se desenvolver como um componente importante no contato com o mundo e na diferenciação das realidades interna e externa, contribuindo para a unidade do self e o reconhecimento da natureza externa do objeto. Por outro lado, se o ambiente se impõe e o movimento parte de fora e não mais do gesto espontâneo do bebê, o que temos é uma vivência de intrusão que o leva a reagir, e a agressividade não se torna mais do que parte das reações à intrusão (Winnicott, 1950-55). Em tais circunstâncias, a agressividade primária deixa de se inscrever psiquicamente enquanto agressividade potencial, que em condições favoráveis adquire um lugar na fantasia, na “...destruição que se dá no inconsciente, na realidade psíquica interna do indivíduo, em sua vida onírica e suas atividades lúdicas, e na expressão criativa." (Winnicott, 1965, p.180).

Num contexto desfavorável, portanto, a agressividade fica subordinada às intrusões do ambiente, só podendo se expressar de forma reativa e produzindo efeitos nefastos que trazem consigo uma ameaça social (Garcia \& Damous, 2008; Lejarraga, 2012). Prevalece uma tendência à destruição (Roussillon, 1991) que se torna característica central e efetiva da clínica com pacientes cuja agressividade não foi bem manejada pelo ambiente, como é o caso dos pacientes limítrofes (Winnicott, 1969 [1968]; Roussillon, 1991; Garcia \& Damous, 2008; Lejarraga, 2012):

De fato, a clínica dos limites, como vem sendo conhecida, expressa pungentemente essas dificuldades experimentadas nas relações precoces com o ambiente, especificamente no que diz respeito ao manejo da agressividade na clínica. (...). ...Este estado de coisas resulta então na emergência da agressividade enquanto sintoma, tão evidenciado nos desenlaces extra-representativos que caracterizam os casos-limite, esses pacientes que causam significativa inquietação na clínica em função dos ataques destrutivos que empreendem. (Garcia \& Damous, $2008: 135)$

A impossibilidade de experimentar a agressividade com uma "liberdade suficientemente boa" (Garcia \& Damous, 2008, p. 127) incidirá sobre a capacidade de reconhecimento da externalidade do objeto, bem como à própria delimitação das fronteiras egoicas, prejudicando os momentos finais do percurso 
rumo à diferenciação interno/externo, a que Winnicott (1969 [1968]) conceituou como o uso do objeto.

Até então, o bebê esteve se relacionando através de fenômenos puramente subjetivos, o objeto não sendo mais que um "feixe de projeções" (Winnicott, 1969 [1968], p. 123), já que ainda não considerado em sua natureza externa. A desadaptação gradual do ambiente torna possível, progressivamente, a percepção do objeto em seu caráter autônomo, sendo necessário, todavia, um movimento da parte do bebê de renúncia da ilusão de onipotência via destruição do objeto subjetivo. Esta consiste numa destruição sem raiva, em que o objeto subjetivo é destruído para ceder lugar à percepção do objeto enquanto parte da realidade compartilhada. Neste ponto, é preciso que o objeto seja "necessariamente real" (Winnicott, 1969 [1968], p.123) e que comporte a capacidade fundamental de sobreviver aos ataques empreendidos pelo bebê na passagem para o campo do uso do objeto. $\mathrm{Na}$ verdade, é a sobrevivência que leva à conquista do uso, já que o ambiente que sobrevive mantém a qualidade dos cuidados e não retalia os ataques destrutivos do bebê, atestando sua existência para além da onipotência primordial. Caso contrário, se o objeto não sobrevive aos ataques, não temos mais que uma nova expressão da onipotência, prejudicando o reconhecimento da autonomia do objeto, bem como a delimitação das fronteiras interno/externo e a capacidade de estabelecer relacionamentos entre pessoas totais.

Foi no contexto de atendimento aos pacientes borderline que Winnicott (1969 [1968]) criou seu conceito de uso do objeto (Lejarraga, 2012), justamente pelo fato de a destrutividade efetiva - tão presente nestes casos - consistir numa tentativa atuada de pôr o analista para fora da área dos fenômenos subjetivos. Deste modo, a tarefa analítica centraliza-se na conquista do uso do objeto, ao menos num primeiro momento, o analista devendo sobreviver aos ataques empreendidos pelo paciente limítrofe, que podem se dar fenomenologicamente de diversas maneiras.

Neste ponto, para compreender os ataques dos casos-limite dirigidos ao analista e à técnica analítica (Winnicott, 1969 [1968]), procuraremos uma descrição do que alguns autores compreendem como os ataques ao enquadre (Green, 2010 [1988]); André, 2002; Figueiredo, 2003b; Garcia, 2010 [2007, 2009]; Damous, 2012a, 2012b) enquanto expressão da destrutividade que infiltra o contexto analítico na clínica com estes casos (Green, 2002). A descrição dos 
ataques feita pelos autores selecionados não articula, todavia, os ataques ao enquadre a uma tentativa de passagem para o campo do uso do objeto em Winnicott (1969 [1968]), sendo este o objetivo do nosso trabalho. Antes, porém, de tentar circunscrever e definir os ataques ao enquadre, será necessária uma descrição dos casos-limite no que tange às especificidades de sua constituição subjetiva.

De difícil definição, a busca por uma delimitação teórica dos casos-limite por um viés psicanalítico remonta aos anos de 1930, geralmente como casos que não se encontram nem no campo da neurose, nem da psicose, nem da perversão, mas podendo abarcar elementos significativos dessas três estruturas principais. Deste modo, tais pacientes podem apresentar características de diversas configurações psicopatológicas, tornando a tarefa diagnóstica ainda mais árdua e insidiosa (Figueiredo, 2003a). Dos anos de 1930 pra cá, a tentativa de definição em negativo segundo a lógica do "nem, nem, nem" (Figueiredo, 2004, p. 504) ganhou novos contornos com uma melhor especificação clínica e metapsicológica, sobretudo através da literatura francesa não-lacaniana, em que a contribuição de André Green é de grande relevância.

A construção greeniana acerca dos casos-limite considera três parâmetros fundamentais e determinantes para a compreensão clínica e metapsicológica destes casos, a saber: as vicissitudes do objeto, a constituição dos limites intrapsíquicos e intersubjetivos e o trabalho do negativo (Garcia, 2010 [2007]). Com influências significativas de Winnicott e Bion, insistindo ainda no caráter atual e indispensável das formulações freudianas, Green articula a teoria pulsional com as relações de objeto e sua interface ambiental, de modo a conceber uma teoria em que o intrapsíquico e o intersubjetivo permanecem indissociáveis, logo as questões acerca do pensamento e da representação articulam-se intimamente às vicissitudes do objeto.

Green toma sua experiência clínica como ponto de partida para a compreensão metapsicológica dos casos-limite, sobretudo através dos fenômenos que atestam dificuldades no apagamento ou esquecimento do objeto primário, fundamental à construção de representações e ao investimento de objetos substitutos (Green, 2010 [1986; 1988]). As consequências são verificadas na dificuldade de estes pacientes construírem representações, trazendo efeitos de paralisia ao pensamento, implicando também, no âmbito intersubjetivo, em 
relações conturbadas com o objeto-analista, vivenciadas através da dupla angústia de intrusão e separação (Green, 1988 [1975]).

O apagamento do objeto primário é o resultado do trabalho do negativo em seu viés estruturante, que possibilita a construção do espaço da ausência no psiquismo (Green, 2010 [1986; 1988]) ao transformar o objeto em estrutura enquadrante (Green, 2002), como um espaço potencial interno que será investido por representações e novos vínculos objetais. Em condições favoráveis, o objeto se deixa esquecer para depois ser reencontrado, instituindo um movimento que não é nem o da presença absoluta, nem o da ausência radical.

Nos casos-limite, diferentemente, vemos um trabalho do negativo que foge a esta trama, já que o objeto primário torna-se absoluto ao não se deixar apagar, seja por sua presença ou por sua ausência em demasia. Em ambos os casos ausência ou presença demasiadas -, trata-se de uma questão de excesso, que aciona o mecanismo de defesa da clivagem como forma de rejeitar ou excluir os efeitos traumáticos resultantes da qualidade excessiva do objeto, sendo esta a forma possível de se empreender um trabalho do negativo, por sua vez desestruturante.

Em tais condições, não é possível a construção de uma representação do objeto, já que sua presença demasiada provoca uma intrusão que impede qualquer abertura à construção representacional, e sua ausência excessiva prejudica, por outro lado, qualquer concepção imaginária ou metafórica do objeto (Green, 1988 [1975]). Deste modo, o trabalho do negativo malsucedido prejudica as funções psíquicas de ligação, redundando em manifestações extra-representacionais que prevalecem na clínica sob forma de ataques ao enquadre (Green, 2010 [1988]).

Ao tomar a estrutura enquadrante como um modelo teórico-clínico, correlacionando o espaço interno da ausência com o espaço potencial do enquadre (Urribarri, 2010), Green (1988 [1975]) formula que, assim como o objeto primário não se fez esquecer, o enquadre na clínica com os casos-limite não é esquecido isto é, assimilado pelo paciente de modo à ênfase recair sobre o processo -, sendo necessária uma análise mais do continente que do conteúdo. Deste modo, no tratamento dos casos-limite o enquadre "faz barulho", pondo em pauta a questão do objeto absoluto que aciona defesas rígidas do eu de modo a combater os efeitos de excesso, a destrutividade atuando como numa tentativa dramatizada de expulsão do objeto maciço. 
Em termos winnicottianos, já que o setting reproduz os cuidados maternos (Winnicott, 1954) e o ambiente suficientemente bom dos primórdios é aquele “implícito” (Winnicott, 1957), “...que quando vai bem dificilmente é percebido...” (Winnicott, 1960a , p. 49), as falhas graves do ambiente são atestadas quando um trabalho através do setting se impõe, sobretudo em momentos de intensa regressão comumente empreendidos pelos pacientes borderline.

De todo modo, tais pacientes são aqueles cujos sintomas têm de ser analisados a partir ou através do setting, trazendo à tona a questão da intrusão do ambiente original e da impossibilidade de serem potencialmente agressivos, bem como a da própria precariedade dos limites internos e externos do eu.

É justamente nas situações em que não se deu a diferenciação eu/não-eu e em que o objeto continua a ocupar o espaço psíquico, impedindo portanto a construção de um espaço potencial que favoreça a simbolização, que se manifesta a agressividade... ...para com um objeto com que se está de fato embolado. (...). ...E assim nos remetemos às recidivas, irrupções de agressividade e colapsos periódicos que os casos limite podem apresentar, principalmente na intimidade de relacionamentos como a transferência analítica (Green, 1975). Estariam eles tentando encontrar um ambiente estável e seguro, resistente e continente às suas manifestações agressivas e deste modo encontrar a oposição necessária que falhou nos primórdios de suas relações de objeto? (Garcia \& Damous, 2008 : 133)

Seguindo esta linha de raciocínio, perguntamo-nos se os frequentes ataques ao enquadre, além de buscarem o contato com uma oposição eficaz, consistiriam numa tentativa atuada de destruição do objeto subjetivo, numa busca clínica de passagem para o campo do uso do objeto? Sabemos que a mudança para o uso vem acompanhada de ataques destrutivos ao analista e à técnica analítica (Winnicott, 1969 [1968]), que demandam de ambos uma sobrevivência imprescindível à concretização de tal tarefa clínica que, uma vez realizada, pode trazer os maiores ganhos ao paciente no âmbito das relações intersubjetivas.

Embora o presente trabalho considere a vertente intrapsíquica dos ataques ao enquadre - intimamente relacionada à construção metapsicológica dos casoslimite em Green, sobretudo acerca dos prejuízos representacionais que recaem sobre o método -, nossa leitura priorizará a vertente intersubjetiva dos fatos, já que o fim do percurso - dos ataques até o uso do objeto - resulta da busca pelo estabelecimento de relações entre pessoas totais, um encontro prejudicado no contexto ambiental original. 
Sendo assim, teremos alguns desafios a atravessar nesta dissertação. Nos principais dicionários de psicanálise (Laplanche \& Pontalis, 2001 [1982]; Roudinesco \& Plon, 1998 [1997]), não encontramos nenhum vocábulo referente às formas habituais de nomear o contexto analítico, seja em termos de enquadre, setting, dispositivo, contexto ou situação analítica. Deste modo, ficará a nosso cargo recorrer aos principais autores na tentativa de circunscrever o locus psicanalítico. A compreensão dos ataques ao enquadre, mais ainda, estará baseada nas escassas descrições encontradas, sobretudo, na literatura francesa e brasileira, contando ainda com o impasse de o termo ser muitas vezes citado, porém não descrito.

Como a interlocução entre as diferentes linhas de pensamento greeniana e winnicottiana em nossa temática demanda um grande esforço de entretecimento teórico, residindo, ainda, entre um e outro, a problemática do enquadre analítico, foi somente possível vislumbrar a construção da dissertação em quatro capítulos independentes, ficando a comunicação entre Green e Winnicott a cargo da última parte do trabalho. O eixo da escrita, no entanto, se guiará pela esfera dos limites, atentando para os limites paradoxais entre o bebê e o ambiente winnicottianos; os intrapsíquicos e intersubjetivos tão destacados por Green; e os limites do enquadre/ setting/ situação analítica proporcionando potencialidades, mas também invocando impasses e sugerindo remanejamentos.

Assim, no primeiro capítulo, buscaremos a compreensão do uso do objeto em Winnicott (1969 [1968]), sendo necessário, para isto, retomar as principais conquistas do desenvolvimento emocional primitivo (Winnicott, 1945), considerando ainda o papel importante da agressividade na diferenciação entre as realidades interna/externa (Winnicott, 1950-55). Serão priorizados, portanto, os aspectos relevantes do percurso maturacional que instauram, progressivamente, a diferença entre o dentro e o fora, o eu e o não-eu, atentando para as falhas graves que interrompem este percurso, tal como é o caso dos pacientes borderline.

Pelo fato de a dissertação repousar sobre uma problemática referente aos casos-limite, será necessário buscar uma definição destes casos, cujo histórico remonta a uma dificuldade em designar-lhes uma circunscrição psicopatológica singular. Deste modo, o segundo capítulo consistirá nas principais formulações de André Green a respeito da constituição subjetiva limítrofe, tomada por ele, diferentemente de outros autores, como uma organização específica e original 
(Green, 1990 [1986]). Será considerada a constituição dos limites intrapsíquicos e intersubjetivos, dentro do que Green (1990 [1986]) nomeou como a "metapsicologia dos limites", incluindo em sua descrição as vicissitudes do objeto primário e os efeitos de um trabalho do negativo que não cumpriu sua função, tornando o mecanismo da clivagem preponderante nestes casos e impedindo a constituição do espaço da ausência no psiquismo (Green, 2010 [1986; 1988]).

O terceiro capítulo será dedicado às principais construções a respeito do enquadre/ setting/ situação analítica, a começar pelos textos técnicos de Freud (1904; 1912a; 1913; 1915 [1914]) onde são estabelecidas recomendações e premissas básicas para a instauração de uma análise. Seguido a Freud, o setting em Winnicott $(1954 ;$ 1955-56) será pensado como uma esfera clínica de largo alcance para os pacientes que não puderam contar com um ambiente suficientemente bom, considerando a regressão à dependência na relação com o analista como algo fundamental aos pacientes falso self - onde se incluem os borderlines -, e o holding clínico nestes momentos em que a interpretação se torna um elemento intrusivo. As contribuições de Baranger (1961-62) e Bleger (1967) serão aproveitadas, respectivamente, no que tange à concepção da situação analítica como um campo dinâmico, e na necessidade de se efetuar uma ruptura do enquadre como forma de trazer para dentro do processo os elementos mais primitivos, de ordem simbiótica, depositados no não-processo de forma inconsciente e muda.

O quarto e último capítulo abrangerá a clínica dos casos-limite, compreendendo as particularidades na forma como o enquadre é experimentado por estes pacientes, considerando ainda as dificuldades trazidas por uma transferência que se estabelece de modo paradoxal (Roussillon, 1999a; 2002a), somada à ampla gama de identificações projetivas em virtude das fronteiras incertas entre o eu e o outro (Figueiredo, 2003a). Aqui, finalmente, será empreendida uma descrição dos ataques ao enquadre, considerando a emergência das problemáticas da destrutividade e da realidade enquanto duas vertentes que impulsionam os ataques, mas também se incluem nos prolongamentos do uso do objeto.

Assim, tentaremos, através deste percurso teórico, construir o argumento de que os ataques ao enquadre empreendem uma tentativa de passagem para o 
campo do uso do objeto, com toda a pesquisa bibliográfica aqui presente auxiliando-nos enormemente em nossa clínica cotidiana 


\section{Winnicott e o percurso até a conquista do uso do objeto}

Donald Winnicott, a partir de sua experiência como pediatra e psicanalista, construiu uma teoria do desenvolvimento emocional primitivo (Winnicott, 1945) destacando elementos da relação mãe-bebê fundamentais e indispensáveis para o amadurecimento do ser humano dentro de um determinado contexto de provisão e cuidado. Neste percurso, fundamentou o processo de diferenciação do bebê em relação ao mundo externo, partindo da dependência absoluta, passando pela dependência relativa, rumo à independência (Winnicott, 1963a), de um estado inicial em que o bebê encontra-se totalmente fusionado ao ambiente, e, portanto, indiferenciado dele, até o reconhecimento da externalidade, possibilitando o relacionamento entre pessoas totais. Neste caminho, o autor considera e valoriza o estatuto do objeto - tanto interno quanto externo - lado a lado com o amadurecimento emocional do infans, desde a concepção do objeto subjetivo até a percepção do objeto objetivamente percebido, distinto do eu (Winnicott, 1969 [1968]).

É a importância do ambiente para o desenvolvimento dos processos maturacionais que confere a Winnicott sua característica específica, a saber, a compreensão do bebê de forma indissociada do ambiente, podendo sua posição teórica ser condensada em sua frase célebre: "Isso que chamam de bebê não existe" (Winnicott, 1952a, p.165). Desta maneira, não há como o bebê existir sem os cuidados maternos, sendo esta premissa o ponto nodal de sua teoria do desenvolvimento emocional primitivo, e o que confere a Winnicott um de seus diferenciais se comparado a outros autores. Isto não significa que teóricos anteriores, desde Freud, não tenham considerado o ambiente, porém este já estava dado, não sendo necessário pensar suas vicissitudes e implicações para os primórdios da vida psíquica. A centralidade do Édipo, inquestionável até então, é minimizada por Winnicott por uma questão de foco ou ênfase. Não que o autor, por sua vez, não reconhecesse o lugar da trama edípica na teoria e prática analíticas, porém o atendimento a pacientes psicóticos e borderlines levaram-no a buscar nas raízes da constituição psíquica - ou nos estágios de pré-integração numa unidade individual - o suporte necessário à compreensão destes casos e seu 
manejo clínico para além da relação transferencial entre pessoas totais (em que a integração do ego é dada como certa), chegando até os estágios de indiferenciação do sujeito com o ambiente/analista através da regressão em análise (Winnicott, 1954).

Vemos em Winnicott que no processo de delimitação entre o interno e o externo, que atravessa todo o percurso de constituição subjetiva, é crucial o papel desempenhado pela a agressividade em prol do reconhecimento da externalidade e do objeto enquanto tal. Neste contexto, a agressividade adquire relevância princeps na temática da distinção eu/não-eu, sendo considerada desde suas raízes primitivas e inintencionais - referentes à oralidade, à atividade e à motilidade (Winnicott, 1950-55) - até a conquista do uso do objeto, por meio da destruição do objeto subjetivo (Winnicott, 1969 [1968]).

A agressividade primária incide sobre uma "oposição" (Winnicott, 1950-55, p. 298) ou resistência do ambiente, ilustrada na própria corporeidade da mãe ou na materialidade do ambiente físico que deste modo se faz reconhecer, atestando a diferença eu/não-eu (Lejarraga, 2012). Todavia, o amplo reconhecimento da externalidade advém, em última instância, da sobrevivência e da não-retaliação do ambiente frente à destruição do objeto subjetivo, conferindo autonomia ao objeto para além do controle onipotente do bebê. É somente nestas circunstâncias que se adquire a capacidade para se relacionar entre pessoas totais:

...Trata-se de uma posição a que o indivíduo pode chegar em fases primitivas de crescimento emocional só através da sobrevivência real de objetos catexizados, que se encontram, na ocasião, em processo de serem destruídos por serem reais, de se tornarem reais por serem destruídos. (Winnicott, 1969 [1968] : 126)

Caso o ambiente não sobreviva, a diferenciação eu/ não-eu é prejudicada naquilo que ela traz de reconhecimento da realidade externa e, concomitantemente, de instauração dos próprios limites egoicos.

Nos casos borderline, a experiência agressiva é prejudicada junto a um ambiente que não sustenta o caráter impiedoso da agressividade primária, impondo um movimento que parte de fora do indivíduo, impedindo a expressão espontânea da agressividade que se torna, por sua vez, reativa. As falhas graves do ambiente provocam no bebê uma vivência de intrusão, instaurando uma série de 
reações que acabam se tornando o único meio possível de expressão da agressividade não bem manejada pelo ambiente (Winnicott, 1950-55).

As consequências são vistas numa agressividade que se torna efetiva, cujo resultado é uma tendência à destruição (Roussillon, 1991) que se expressa através de atitudes anti-sociais (Garcia \& Damous, 2008). Na clínica, a destrutividade se torna a característica central, sugerindo uma não-sobrevivência do ambiente original, impossibilitando à destrutividade adquirir um lugar potencial interno, na fantasia (Winnicott, 1969 [1968]). Deste modo, os ataques destrutivos empreendidos ao analista e à técnica analítica sugerem a busca pela conquista do uso do objeto, na clínica, atestando ainda a prevalência de uma relação que permanece ligada à vertente subjetiva do objeto.

\section{1}

\section{Primeiras delimitações eu/não-eu: integração, personalização e realização}

$\mathrm{Na}$ teoria winnicottiana, o desenvolvimento emocional primitivo não pode se dar de forma satisfatória a menos que haja uma facilitação por parte do ambiente. O bebê possui tendências inatas ao desenvolvimento, mas elas serão impulsionadas por um ambiente capaz de responder às suas necessidades primárias, representado pela mãe ou por um cuidador que se ocupe da criança de forma devotada e contínua no tempo. Winnicott nomeou de ambiente suficientemente bom (Winnicott, 1956) este contexto de provisão que abrange a totalidade dos cuidados maternos bem no início da vida do bebê, na medida em que oferece condições favoráveis ao seu desenvolvimento físico e emocional. Pelo termo favorável entende-se uma forma coerente de perceber, no tempo e no espaço, as necessidades do bebê, o que leva a mãe “...a providenciar alguma coisa mais ou menos no lugar certo e no momento certo" (Winnicott, 1952b, p. 311), de acordo com as necessidades a princípio corporais, e em seguida necessidades do ego, quando o bebê torna-se capaz de construir uma "elaboração imaginativa" (Winnicott, 1956, p. 403) de suas experiências físicas. É somente através de um estado de extrema identificação que a mãe adquire em relação ao bebê, estado este que Winnicott (1956) denominou preocupação materna primária, que ela poderá entrar em sintonia com ele e então se ajustar às suas necessidades reais. 
Neste contexto, não se trata ainda de satisfação ou frustração de impulsos do id - o que implicaria numa lógica desejante -, visto que, para Winnicott, a questão da necessidade é distinta e anterior à do desejo. A qualidade do que é provido em cada um desses âmbitos (necessidade ou desejo) traz diferentes consequências, e quando a adaptação à necessidade não se cumpre, o que temos não é raiva frente à frustração, mas uma "distorção" (Winnicott, 1956, p.400) do desenvolvimento, que traz consigo uma "ameaça de aniquilação" (ibid., p.403) nesta etapa bastante inicial em que o ego é ainda um ego primitivo, incipiente. Só após o ego tornar-se uma unidade integrada, se tudo correr bem, é que poderá experimentar os impulsos provenientes do id, e só então fará sentido pensar em termos de satisfação e frustração.

No período em questão, o bebê e a mãe estão indiferenciados e fusionados um com o outro, e o bebê está em dependência máxima do ambiente. Para o observador, existem duas pessoas de carne e osso, mas no cerne da relação mãebebê o que há por hora é uma mônada, uma unidade única indiferenciada. Então, na perspectiva do bebê, ele e a mãe/ambiente não são mais que um:

Nos estágios iniciais a dependência do ambiente é tão absoluta que não há utilidade alguma em pensarmos no novo indivíduo humano como sendo ele a unidade. Nesse estágio, a unidade é o conjunto ambiente-indivíduo (ou um nome mais adequado que se lhe possa dar), unidade da qual o novo indivíduo é apenas uma parte. Neste estágio tão inicial não é lógico pensarmos em termos de um indivíduo, e não apenas devido ao grau de dependência ou apenas porque o indivíduo ainda não está em condições de perceber o ambiente, mas também porque ainda não existe ali um self individual capaz de discriminar entre o EU e o não-EU. (Winnicott, $1990: 153$ )

Na dependência absoluta, o ego do bebê encontra-se num estado de "nãointegração primária" (Winnicott, 1945, p. 223), sendo algo que a clínica com pacientes psicóticos e borderline vem posteriormente confirmar. Para que o bebê se sinta uma unidade, inserido em seu próprio corpo e podendo diferenciar aquilo que não é parte de sua imaginação, é preciso que ele atravesse os processos que Winnicott (1945) nomeou de integração, personalização e realização.

A integração se inicia no começo da vida, tendo o bebê uma tendência inata a ir nesta direção. Ele nada poderá fazer, contudo, se estiver sozinho nesta situação. Ele só poderá começar a se sentir uma unidade, isto é, uma pessoa com individualidade própria, através de um “ambiente facilitador" (Winnicott, 1963b, 
p.201), representado pelos cuidados devotados da mãe. Neste âmbito, uma maternagem suficientemente boa implica em segurar o bebê, niná-lo, mantê-lo numa temperatura confortável, dar-lhe banho e chamá-lo pelo nome; tudo isto aliado às experiências instintivas ${ }^{3}$ que tendem a integrar sua personalidade, organizar seu interior e instaurar as primeiras vivências de gratificação. O cumprimento da rotina dia e noite de cuidados consistentes - acrescidos à empatia materna - que envolvem a satisfação das necessidades fisiológicas mas também levam em conta a sensorialidade e a proteção contra a queda, todo este conjunto foi chamado por Winnicott (1960a) de holding, entendido como “...a provisão ambiental total anterior ao conceito de viver com." (Winnicott, 1960a, p.44. Grifo do autor.). A expressão "viver com" designa a capacidade de o bebê perceber os objetos como externos a ele, algo que ainda não é possível neste momento.

...Neste estado o lactente não tem meios de perceber o cuidado materno, que é em grande parte uma questão de profilaxia. Não pode assumir controle sobre o que é bem ou mal feito, mas apenas está em posição de se beneficiar ou de sofrer distúrbios. (Winnicott, 1960a : 45-46)

Deste modo, é o ambiente capaz de oferecer um holding suficientemente bom, através do "ego auxiliar da mãe" (Winnicott, 1962, p.56), que irá estimular o "potencial herdado" (Winnicott, 1960a, p. 47) ou a tendência inata ao desenvolvimento neste estágio inicial da dependência absoluta. A partir desta sustentação ambiental, de uma mãe capaz de "emprestar" seu ego em função de sua capacidade identificatória, é que poderá se dar a integração do ego do bebê, que inclui também uma integração no tempo e no espaço (Winnicott, 1962).

A provisão adequada através do ego auxiliar permite a experiência de onipotência (Winnicott, 1962; 1971b), pois o que a mãe oferece condiz sincronicamente com aquilo que o bebê necessita, e somente nestas condições pode emergir o gesto espontâneo (Winnicott, 1960b) enquanto expressão do verdadeiro self em formação. Aqui, Winnicott lança mão da hipótese de uma primeira mamada teórica enquanto situação exemplar para pensar o que ocorre ao bebê em termos de criatividade primária. Por se tratar de uma primeira mamada, não há ainda material mnêmico através do qual o bebê alucine o objeto de satisfação. Neste interjogo, o que há é uma necessidade e o oferecimento do seio

\footnotetext{
${ }^{3}$ Preferiremos o termo instinto a pulsão, por fidelidade ao autor.
} 
no momento certo, e a superposição destes dois elementos cria a ilusão de o próprio bebê ter criado o objeto.

A criatividade primária é inerente à ilusão de onipotência, já que, para o bebê, o seio é criado por ele e está sob seu controle mágico. Isto confere um teor de atividade criativa ao bebê enquanto prerrogativa para os futuros relacionamentos entre pessoas totais, pois um bebê “...que mama de um modo inteiramente passivo nunca poderá criar o mundo, e portanto não será capaz de construir relacionamentos externos, nem terá futuro como indivíduo." (Winnicott, 1990, p. 128)

Então o bebê se relaciona, a princípio, com objetos subjetivamente concebidos (Winnicott, 1969 [1968]), havendo ainda um caminho relativamente longo a ser percorrido para que os objetos sejam considerados com natureza própria, conforme a ilusão for dando margem à desilusão, com a desadaptação gradual da mãe somada ao crescimento emocional, físico e intelectual do bebê. $\mathrm{Na}$ dependência absoluta, a ilusão de onipotência é reforçada pela mãe que prossegue na sua atividade de oferecer o seio na hora exata,

...dando-lhe continuamente aquele pedacinho simplificado do mundo que ele, através dela, passa a conhecer. Somente com base numa fundação desse tipo pode desenvolver-se a percepção objetiva ou a atitude científica. Toda falha relacionada à objetividade, em qualquer época, refere-se à falha nesse estágio do desenvolvimento emocional primitivo. Somente com base na monotonia pode a mãe adicionar riqueza de modo produtivo. (Winnicott, $1945: 228$ )

A fidedignidade da mãe, que evita mudanças bruscas no tempo e no espaço, instaura uma confiabilidade no ambiente que se mantém coerente e coeso, e outras mamadas se seguirão com a possibilidade de o bebê vivenciar momentos de relacionamentos excitados, instintivos, predatórios. Os estados excitados irão se intercalar com os estados tranquilos, sendo fundamental a oscilação entre ambos. O momento tranquilo constitui a base para o momento excitado, e é onde o bebê poderá se recuperar da tensão instintiva, de certa forma mantendo viva a satisfação através do brincar ou da fantasia, preparando-se para uma nova mamada (Winnicott, 1990). A constância do ambiente, além de permitir o trânsito do bebê entre os dois estados, facilita o cumprimento dos demais processos do 
desenvolvimento, a saber, a personalização e a realização ${ }^{4}$, na linha de continuidade do ser do bebê.

No que tange à personalização, o "sentimento de estar dentro do próprio corpo" (Winnicott, 1945, p. 225), tomado por muitos como algo óbvio, é para Winnicott uma conquista. A unificação entre psique e soma é auxiliada pela função de handling materno, correspondente ao "manejo" (Winnicott, 1962, p.60) ou manuseio corporal que traz maior segurança ao bebê, fazendo com que ele se sinta inserido dentro de um determinado contorno, isto é, o corpo que habita. A personalização ocorre, portanto, como uma conquista na qual a psique passa a habitar o soma, o bebê se tornando capaz de relacionar-se com seu corpo e suas funções corporais, e com sua pele enquanto "membrana limitante", (Winnicott, 1960a, p. 45) ou "limite entre o eu e o não-eu" (ibid., p. 60).

Assim, é também através do conjunto das vivências instintivas e da experiência "repetida e silenciosa" (Winnicott, 1945, p. 225) de ser cuidado fisicamente que uma unidade psicossomática pode ser alcançada. O bebê se apropria de suas experiências motoras e sensoriais, e ganham sentido "as funções de entrada e saída" (Winnicott, 1960, p. 45). Com a sensação de habitar o próprio corpo, vai-se construindo uma realidade psíquica interna que, por conseguinte, irá se contrapor ao que é exterior, e "agora então o crescimento do lactente toma a forma de um intercâmbio contínuo entre a realidade interna e a externa, cada uma sendo enriquecida pela outra." (Winnicott, 1963a, p. 86). Deste modo, os cheiros, sons e expressões faciais enquanto fragmentos do cuidado materno se reunirão numa só pessoa, que poderá ser chamada de mãe - não mais do ponto de vista do observador, mas do bebê que passa a reunir esses traços numa só pessoa.

$\mathrm{Na}$ medida em que o bebê prossegue em seu desenvolvimento, a mãe, por sua vez, vai retornando para os demais aspectos de sua vida. Inicia-se, então, uma etapa em que a apresentação de objetos, por parte da mãe, leva o bebê a se conscientizar de que os elementos do mundo externo não são parte de sua imaginação. Aqui começa a se instaurar o princípio de realidade, e o processo de realização traz a “...capacidade de o infante começar a discriminar aspectos não eu

\footnotetext{
${ }^{4}$ Vale notar que, embora Winnicott descreva os processos de integração, personalização e realização de forma didaticamente sequencial, eles se sobrepõem ao longo do processo de desenvolvimento emocional primitivo, no qual se dá também um trânsito saudável entre os estados integrados e não-integrados.
} 
que o circundam." (Oliveira, 2012, p.49). Deste modo, a realização está em consonância com a compreensão intelectual, auxiliando o bebê a distinguir o que não faz parte dele próprio. $\mathrm{O}$ infans se torna então capaz de transmitir sinais e assim guiar a mãe na direção do que ele precisa, ao passo que ela destitui-se do lugar de compreender quase que magicamente suas necessidades. Este é o momento da dependência relativa, período que vai de aproximadamente seis meses a dois anos de idade (Winnicott, 1963a). A partir de então, o bebê pode se dar conta dos cuidados maternos e do fato de lhe serem necessários, e demonstrar suas necessidades através do choro e protesto intencionais. Por outro lado, a mãe, ao se desadaptar gradualmente, abre espaço para a separação necessária entre ambos. Nos comentários de Dias (2012):

...Isto coincide com a necessidade do bebê de dar prosseguimento ao amadurecimento; a desadaptação da mãe é imprescindível para o início do rompimento da unidade indiferenciada mãe-bebê, de modo a pôr em marcha o longo e vagaroso processo de separação que levará o pequeno indivíduo à integração em um eu unitário e separado, capaz de estabelecer relações com o nãoeu ou o mundo externo. (Dias, $2012: 217$ )

Porém, o contrário se verifica quando a própria mãe encontra dificuldades neste caminho e permanece num estado de fusão com o bebê. Este se verá privado do gesto espontâneo enquanto expressão vital pessoal, e o reconhecimento da externalidade será prejudicado pelo fato de o bebê ou permanecer amalgamado ao ambiente, ou ter de lutar contra ele de forma reativa, o que está longe de configurar um reconhecimento criativo da realidade. A não separação mãe-bebê incidirá finalmente sobre a capacidade de construir relações objetais, já que os próprios processos integrativos do bebê são postos em questão. Nas palavras de Winnicott:

...Poder-se-ia dizer que se ela sabe agora bem demais o que o lactente necessita, isto é mágica e não forma uma base para as relações objetais. (...). Deste modo a mãe, por ser uma aparentemente boa mãe, faz pior do que castrar o lactente; este último é deixado com duas alternativas: ou ficar em um estado permanente de regressão e ficar fundido com a mãe, ou então representar uma rejeição completa da mãe, mesmo de uma mãe aparentemente boa. (Winnicott, 1960a : 50)

Assim, a distinção eu-outro que vai se evidenciando com a separação ou desfusão é favorecida pela mãe capaz de falhar gradualmente em sua adaptação 
inicial, o que é tão necessário para o desenvolvimento maturacional quanto o holding. Neste momento em que a mãe começa a se ausentar e o bebê se vê às voltas com a diferenciação entre o que é interno e externo, inicia-se um fenômeno que é de suma importância para o crescimento saudável, e que se tornará imprescindível ao longo da vida. Estamos falando da instauração dos objetos e fenômenos transicionais, conceito criado por Winnicott em 1951 que tomou lugar central em sua obra, configurando-se como uma de suas maiores contribuições à psicanálise.

\section{2}

\section{Dentro e fora ou nem dentro, nem fora: o paradoxo da transicionalidade}

Na linha de continuidade do ser - e da infinita tarefa de relacionar-se com o mundo externo -, o objeto transicional constitui-se como uma "primeira possessão não-eu" (Winnicott, 1971a, p.13) que traz "um novo sentido de realidade" (Dias, 2012, p.222) ao que era até então vivenciado no âmbito da ilusão de onipotência. Este novo fenômeno se estabelece enquanto um vínculo do bebê para com um objeto que não é mais somente parte dele mesmo - como seu próprio corpo ou como o seio criado outrora - e que tampouco é reconhecido como pertencendo totalmente à realidade externa, compartilhada. Na verdade, o objeto transicional é ambos: criado pelo bebê, mas também encontrado por ele na realidade externa.

O termo transicional remete a uma área de experiência que se instaura na transição entre o bebê estar fundido com a mãe e começar a se relacionar com objetos percebidos como totalmente externos e separados, antes de atingir o estado do EU SOU (Dias, 2012):

...Uma das transições é do controle onipotente dos objetos externos para o abandono do controle e, finalmente, para o reconhecimento de que existem fenômenos que se acham fora de nosso próprio controle pessoal. $\mathrm{O}$ objeto transicional que faz parte tanto do bebê quanto da mãe adquire uma nova condição a que damos o nome de posse. (Winnicott, 1959, p.45. Grifo do autor.)

Neste ponto, Winnicott esclarece que seu estudo não se dirige para “...o primeiro objeto das relações de objeto" (Winnicott 1971a, p.15), mas para o uso 
que o bebê faz desta área intermediária enquanto um novo campo de experiência, localizado “...entre o erotismo oral e a verdadeira relação de objeto, entre a atividade criativa primária e a projeção do que já foi introjetado..." (Winnicott, 1971a, p.14). Neste sentido, o que o autor entende como primeira possessão nãoeu abrange o desenvolvimento da coordenação e o manuseio de objetos que são “diferentes-de-mim" (Winnicott, 1971a, p.16), mas que ainda estão muito entremeados ao objeto subjetivo dentro da esfera pessoal.

Nesta área intermediária, o objeto está localizado concomitantemente "dentro, fora, na fronteira" (Winnicott, 1971a, p. 14), numa terceira área que abrange aspectos subjetivos e objetivos sem que, no entanto, haja um conflito, dada sua natureza aparentemente dicotômica. Na verdade, a localização ou a relação que se dá entre o que é subjetivamente concebido e objetivamente percebido instaura não uma dicotomia, mas um paradoxo característico da transicionalidade, pois o objeto é ao mesmo tempo criado e encontrado pelo bebê (Winnicott, 1971a). A pergunta sobre certificar-se se o objeto é criado ou encontrado não deve jamais ser colocada, sendo de maior importância a sustentação do paradoxo e não a busca por sua resolução.

Mesmo neste período em que a desilusão gradual já se faz sentir, os objetos transicionais dão contorno e continuidade à ilusão - necessária para toda a vida, por permitir que a realidade externa seja vivida com algum sentido pessoal (Dias, 2012) -, na medida em que a onipotência vai sofrendo modificações e perdendo seu vigor inicial. Neste sentido, uma parcela de ilusão se mantém, enquanto que a onipotência de criar e controlar os objetos vai sendo deixada para trás, conforme a realidade externa aferra sua existência própria. A ilusão, que deve prosseguir ao longo da vida, permanece enquanto experiência desta terceira área, estendendo-se para o brincar e todo o campo da cultura - englobando na idade adulta as artes, a religião e a produção científica -, atestando o caráter irrevogável de uma certa indiferenciação interno/externo, própria do humano:

Presume-se aqui que a tarefa de aceitação da realidade nunca é completada, que nenhum ser humano está livre da tensão de relacionar a realidade interna e externa, e que o alívio dessa tensão é proporcionado por uma área intermediária de experiência (cf. Riviere, 1936) que não é contestada (artes, religião, etc.). (Winnicott, 1971a : 28-9) 
Quanto à sua descrição, os objetos transicionais são escolhidos e investidos afetivamente pelo bebê, podendo ser um ursinho de pelúcia, um travesseirinho ou cobertor, e a relação do bebê com o objeto inclui as atividades de pensar e fantasiar. O objeto transicional deve ser de total direito do bebê, não devendo ser modificado, a não ser por ele próprio. É amado, odiado e sobrevive aos ataques de agressividade pura, quando esta se faz presente. Neste sentido, é de suma importância que o objeto seja "real" (Winnicott, 1971a, p.19), isto é, que não seja uma alucinação e que tampouco se restrinja a ser um símbolo do seio ou da mãe. O objeto transicional, ao parecer “...que tem vitalidade ou realidade próprias" (Winnicott, 1971a, p.18), auxilia no reconhecimento da realidade externa, principalmente pelo fato de sobreviver à agressividade inerente ao amor instintual. Em outras palavras, sobreviver garante a autonomia do objeto paraalém da subjetividade do bebê, que começa a se dar conta que a realidade externa escapa ao seu controle onipotente.

O fenômeno transicional pode ainda se expressar através de sons, balbucios da criança ou canções entoadas na hora de dormir, constituindo-se também como uma defesa contra a ansiedade (anxiety) ou um “...lugar de repouso para o indivíduo empenhado na perpétua tarefa humana de manter as realidades interna e externa separadas, ainda que inter-relacionadas". (Winnicott, 1971a, p. 15).

Para que o objeto transicional possa cumprir sua função, é preciso ter havido um cuidado suficientemente bom, que proporcionou a ilusão de onipotência necessária à construção do objeto subjetivo, base para a transicionalidade. Como o fenômeno transicional assenta concomitantemente sobre o interno e o externo, a ilusão de onipotência e o objeto subjetivo tornam-se pré-requisitos (Dias, 2012) para a fruição desta área privilegiada e também, mais tarde, para o reconhecimento da realidade externa. Como lembra Lejarraga (2012), “a experiência de ilusão não se opõe à realidade nem acontece por frustração da realidade, mas, pelo contrário, estabelece uma ponte com a realidade." (Lejarraga, 2012, p. 76). Somente com base num ambiente de confiabilidade e segurança, capaz de prover a ilusão necessária, é que a realidade compartilhada poderá ser reconhecida, sem que, no entanto, o indivíduo tenha que abdicar de aspectos pessoais para relacionar-se com ela. 
Desta perspectiva, é graças às qualidades do objeto externo, no que tange sua “...existência, vitalidade e comportamento" (Winnicott, 1971a, p.24), que o objeto subjetivo vai estabelecer-se de forma assegurada e duradoura, permitindo ao bebê suportar por um período de tempo a ausência da mãe, recorrendo a uma "lembrança ou imagem mental" (Winnicott, 1971a, p.31) dela. O grau de sustentação da ausência varia de caso a caso, porém não deve se exceder para além do que o bebê é capaz de suportar, o que provocaria uma ruptura na continuidade do ser, tendo como resultado a ameaça de aniquilação repleta de agonias impensáveis (Winnicott, 1967). Como observa Dias (2012), pelo fato de o objeto transicional se apoiar sobre o objeto subjetivo, perder o transicional é ainda perder parte de si próprio:

...Nesse estágio, em que o bebê recém começou a diferenciar-se da mãe, a perda não é apenas do objeto, mas de parte de si mesmo, da boca por exemplo. (...). Se o bebê perde o objeto transicional, que está apoiado nos subjetivos correspondentes, ele perde, ao mesmo tempo, a boca e o seio, a criatividade e o caminho para a percepção objetiva. (Dias, 2012 : 230-231)

Desta maneira, o objeto transicional pode ser usado quando o objeto subjetivo “...está vivo, e é real e suficientemente bom (não muito persecutório)" (Winnicott, 1971a, p.24), contribuindo para o contato com a realidade externa e as futuras relações objetais.

Outro aspecto importante do objeto transicional é que com ele tem início o trabalho de simbolização, pelo fato de ele se tornar o representante do objeto subjetivo, representando, indiretamente, o objeto externo. Winnicott destaca, no entanto, que a função simbolizante do transicional não é o mais importante em sua teoria. Além de a realidade do objeto transicional ser mais relevante do que sua possibilidade de representar o objeto interno/externo (Winnicott, 1971a), o autor está mais empenhado em discutir a capacidade de uso e experimentação, pelo bebê, desta terceira área enquanto território da ilusão e do brincar, da criatividade propriamente dita, que não deve ser perdida jamais. Seria injusto afirmar, no entanto, que Winnicott não reconhece o transicional como ponto de partida para o simbolismo, e como aquilo que dá início à distinção entre fato e fantasia, no terreno da experimentação criativa do bebê: 
É verdade que a ponta do cobertor (ou o que quer que seja) é simbólica de algum objeto parcial, tal como o seio. No entanto, o importante não é tanto seu valor simbólico, mas sua realidade. (...). Quando o simbolismo é empregado, o bebê já está claramente distinguindo entre fantasia e fato, entre objetos internos e objetos externos, entre criatividade primária e percepção. Mas o termo objeto transicional, segundo minha sugestão, abre campo ao processo de tornar-se capaz de aceitar diferença e similaridade. Creio que há uso para um termo que designe a raiz do simbolismo no tempo, um termo que descreva a jornada do bebê desde o puramente subjetivo até a objetividade, e parece-me que o objeto transicional (ponta do cobertor, etc.) é o que percebemos dessa jornada de progresso no sentido da experimentação. (Winnicott, 1971a : 19)

A função de representação contida no objeto transicional é crucial quando temos em mente o paciente borderline, cujos prejuízos na capacidade representacional são características marcantes na clínica (Green, 1988 [1975]). De fato, o objeto transicional é o primeiro símbolo da união/separação com a mãe, que se dá no contexto de seus movimentos de presença e ausência. O transicional enquanto a "raiz do simbolismo no tempo" (ibid.) traz subsídios para a capacidade de se relacionar de forma cada vez mais aprimorada com a realidade externa, sendo a rotina e a previsibilidade do objeto indispensáveis para este progresso, a partir de uma constituição satisfatória da imagem interna da mãe.

Por outro lado, quando a existência do objeto externo/real não está assegurada, demonstrando vitalidade e fidedignidade precárias, a lembrança ou "representação interna" (Winnicott, 1971a, p.31) da mãe se desvanece. Por conseguinte, os objetos transicionais também vão perdendo o sentido, sendo gradativamente desinvestidos pelo bebê. Pode ser que um pouco antes da perda efetiva do objeto transicional, ele seja compulsivamente usado como forma de negar que está se tornando sem sentido. Pode ser, inclusive, que não haja objeto transicional que não a própria mãe. Neste caso, não há a construção de uma representação que auxilie na separação e diferenciação dentro/fora, interno/externo quando a fusão segue adiante por mais tempo que o necessário, acarretando problemas na capacidade de simbolização.

Assim, os prejuízos na transicionalidade afetam diretamente a relação com o mundo externo, trazendo consequências para a aquisição da capacidade de uso do objeto. Na melhor das hipóteses, no entanto, o objeto transicional é gradativamente desinvestido pelo bebê que prossegue seu percurso rumo à independência. Na medida em que a criança percebe cada vez mais a realidade compartilhada e adquire interesses culturais, o objeto transicional vai perdendo 
seu significado e espalhando-se por todo o campo da cultura, ampliando-se para o brincar, o sonhar, a apreciação artística, o sentimento religioso, dentre outros elementos que estabelecem uma ponte entre o mundo interno e a realidade externa (Winnicott, 1971a).

Neste processo, no entanto, é importante ressaltar a parcela ativa do bebê, num movimento que não é nem apenas puro desinvestimento do objeto transicional, nem uma passagem automática para o campo do que é socialmente compartilhado (Lejarraga, 2012). Aqui, o que de mais importante está em jogo é a destruição do objeto subjetivo. Antes mesmo do desinvestimento, o próprio uso do objeto transicional coincide com o início da destruição do objeto subjetivo, dentro do que Winnicott (1969 [1968]) desenvolveu como o percurso que vai da relação até o uso do objeto, que é quando o bebê conquista a capacidade de se relacionar com pessoas totais. No que tange à relação entre destruição, transicionalidade e criação da realidade, Lejarraga (2012) observa bem:

\begin{abstract}
...O bebê usa o objeto transicional e também destrói o objeto na fantasia. O objeto destruído é o subjetivo, quer dizer, os aspectos subjetivos do objeto transicional e, principalmente, a mãe como objeto subjetivo. Desse modo, o objeto transicional não é só criado e achado, como também, destruído e achado. (...). Em síntese, vemos que tanto a ilusão quanto a destrutividade desempenham papel fundamental na constituição da realidade. (Lejarraga, $2012: 82-83$ )
\end{abstract}

Desta forma, o percurso de diferenciação interno/externo conduz à conquista do uso do objeto, que atesta a existência da realidade externa ao mesmo tempo que afirma a integração do indivíduo num self unitário, pessoal, distinto do meio. Para isto, é necessário não somente um ambiente onde possa ser vivenciada a ilusão, mas também a agressividade com seus componentes destrutivos, desde suas raízes inconscientes e inintencionais, até o sentimento de responsabilidade, culpa ou concernimento (concern) para com o outro, percebido agora como o objeto dos ataques destrutivos. Continuaremos este caminho teórico até a conquista do uso do objeto, não sem antes compreender um pouco mais o que para Winnicott se configura como agressividade na relação com o ambiente, indispensável ao reconhecimento da realidade externa. 


\section{3}

\section{O papel da agressividade na construção da externalidade}

Winnicott, ao considerar os momentos iniciais de não-integração egóica e indiferenciação indivíduo-ambiente em sua teoria do desenvolvimento emocional primitivo, mostrou-se preocupado em distinguir a raiva ou o ódio ${ }^{5}$ da agressividade e suas raízes primitivas. No texto A agressividade em relação ao desenvolvimento emocional (1950-55), o autor tenta dar conta da questão, ao buscar as raízes da agressividade em aspectos que abrangem a atividade e a motilidade do bebê, e também a experiência instintiva, no que concerne primariamente à oralidade e seus meandros, ambos no contexto da dependência absoluta.

A motilidade é uma das raízes primitivas da agressividade enquanto "força vital” (Winnicott, 1950-55, p. 303) que consiste em exploração e descoberta do ambiente, e que se faz presente desde a vida intra-uterina, através dos impulsos musculares do feto. Aqui, no entanto, a força vital só se transforma em agressividade se houver uma "oposição" (Winnicott, 1950-55, p.298) do ambiente, que é uma espécie de resistência do meio externo perante o qual o indivíduo “...precisa de algo para empurrar” (Winnicott, 1950-55, p.298): a materialidade física do ambiente, como o próprio corpo da mãe. Deste modo, a oposição atesta a existência de algo que é da ordem do não-eu, e...

...a agressividade, assim, na sua raiz motora, é responsável pelo contato com o mundo externo, constituindo a porta de entrada para a realidade compartilhada. (...). Se não existisse oposição, a motilidade do bebê se diluiria no vácuo, impedindo-o de tomar consciência de sua força muscular, de seu potencial agressivo e da existência de um mundo externo real. (Lejarraga, $2012: 49 ; 51$ )

No que concerne à oralidade, a satisfação da necessidade vem acompanhada de elementos vorazes inerentes à vontade de ingerir o objeto que faz cessar a fome. Deste modo, ao sugar o leite, o bebê morde o seio da mãe com as gengivas, sendo algo que é parte da expressão do amor primitivo (Winnicott, 1950-55; Lejarraga, 2012).

\footnotetext{
${ }^{5}$ Raiva e ódio serão utilizados como termos equivalentes, ambos diferindo do conceito de agressividade em sua origem e suas funções, tal como entendido por Winnicott (1950-55).
} 
Segundo Winnicott, em sua tentativa de distinguir a agressividade do ódio, nos momentos iniciais do desenvolvimento emocional não é possível falar em raiva ou ódio provenientes da frustração, já que o ego precisa estar integrado para que as experiências sejam vividas nesses termos. Neste aspecto, ele adota uma posição teórica distinta de Freud e Klein, para os quais a existência do ódio está presente desde sempre (Rodulfo, 2009). Para Freud, o ódio antecede o amor (Freud, 1915), expressando-se, no início, através da expulsão do desagradável (Freud, 1925). Para Klein, amor e ódio são forças arcaicas e simetricamente opostas, e sua dicotomia mais intensa pode ser encontrada na posição esquizoparanóide através da dissociação do objeto em bom/mau, idealizado/persecutório. Tanto para Freud quanto para Klein, a problemática que gira indistintamente em torno do ódio, da agressão e da agressividade permanece “...confusamente misturada com - e confiscada por - a morte e o mortífero.” (Rodulfo, 2009, p.129. Tradução nossa.), estando sua raiz vinculada necessariamente à pulsão de morte. $\mathrm{Na}$ teoria winnicottiana, diferentemente, a agressividade "...é uma das muitas fontes de energia de um indivíduo" (Winnicott, 1939, p. 103), fazendo parte do movimento vital de criação e descoberta do mundo, e diferindo do ódio em diversos aspectos maturacionais, circunstanciais e de finalidade. Deste modo,...

\begin{abstract}
...Winnicott não assimila agressão $=$ pulsão de morte $=$ destrutividade $=$ originariedade primitiva como, entre outros, o faz Klein, quem simplifica a oposição amor-ódio como forças simétricas arcaicas que já se encontram ali. A possibilidade de odiar é relativamente tardia... (...). ...o ódio não deve banalizar-se: implica a possibilidade de investir em alguém como inimigo e como outro; é impensável sem um claro reconhecimento de sua alteridade..." (Rodulfo, 2009 : 139-40. Grifo do autor. Tradução nossa.).
\end{abstract}

Neste sentido, o sentimento de ódio na teoria winnicottiana pressupõe o reconhecimento do objeto em sua natureza externa, o que ainda não é possível neste momento. Embora a agressividade tenha papel fundamental no reconhecimento da externalidade, sobretudo em termos de destrutividade ${ }^{6}$ no estágio do uso do objeto (Winnicott, 1969 [1968]), será preciso, antes, compreendermos determinadas nuances da agressividade que se fazem presentes

\footnotetext{
${ }^{6}$ Em função de muitas vezes Winnicott utilizar indiscriminadamente os termos agressividade e destrutividade, não efetuaremos, aqui, uma discussão terminológica. No estágio do uso do objeto, contudo, a agressividade será pensada prioritariamente em termos de destrutividade, pelo fato de empreender o movimento fundamental de destruição do objeto subjetivo.
} 
anteriormente, e que também auxiliam no processo de individuação e diferenciação eu-outro.

Segundo Winnicott (1950-55), a fonte da agressividade reside na experiência instintiva, no sentido de o erotismo oral atrair para si elementos agressivos que fazem parte da capacidade de amar e de se relacionar com objetos. Nos momentos mais iniciais, podemos dizer que a agressividade é impiedosa (ruthless), pois o bebê não tem ainda a intenção de destruir e não está ciente dos efeitos de seus atos: "Do ponto de vista do bebê, ele não pode ser descrito como odiando ou desejando destruir a mãe nesse estágio, mas somente como a amando descuidadamente.” (Phillips, 1988, p. 156) Neste sentido, os ataques inerentes à oralidade são efetuados de forma cruel, pois o que há é uma "ausência de concernimento" (Winnicott, 1950-55, p. 290) para com o objeto ao qual os ataques se dirigem.

Neste contexto, na verdade, o que chamamos de objeto - talvez inadequadamente, porém sem alternativa terminológica - não é o objeto enquanto tal, reconhecido em sua natureza externa, pois é somente a partir da integração do bebê que os fragmentos do objeto poderão ser também integrados numa entidade única. Sendo assim, o bebê não possui meios de perceber que o objeto que ele destrói em seus estados excitados - que incluem um “...ataque imaginário ao corpo da mãe" (Winnicott, 1950-55, p.291) -, é o mesmo que ele valoriza em seus intervalos tranquilos. No início, portanto, os efeitos destrutivos são meros incidentes junto à satisfação:

Em primeiro lugar, existe uma voracidade teórica ou amor-apetite primário, que pode ser cruel, doloroso, perigoso, mas só o é por acaso. O objetivo do bebê é a satisfação, a paz de corpo e de espírito. (...). É evidentemente importante para a criança em desenvolvimento que ela tenha se encolerizado com frequência numa idade em que não precisa sentir remorso. (Winnicott, 1939 : 97)

No momento mais inicial, portanto, a agressividade impiedosa é parte do gesto espontâneo e da criatividade primária, sendo fundamental que o bebê possa, neste momento, vivenciar a agressividade de maneira despreocupada e somente progressivamente dar-se conta dos estragos que causa ao objeto amado. Além disso, é essencial que se possa contar com a reunião dos elementos agressivos e eróticos, pelo fato de esta conjunção proporcionar o caráter de realidade às experiências vividas. 
Neste sentido, Winnicott (1950-55) sugere que a força vital motora deve imiscuir-se ao máximo nas experiências instintivas do id, configurando assim uma fusão do potencial agressivo com o potencial erótico. No cerne das experiências do id, portanto, está incluída certa gama de motilidade, e o que resta de motilidade não-fusionada deverá ser utilizada para outros fins, como, por exemplo, para objetivos puramente motores. As quantidades fusionadas e não-fusionadas são distintas em cada indivíduo, o que resulta em três padrões referentes ao modo de lidar com a agressividade (Winnicott, 1950-55).

No primeiro padrão, o indivíduo pode contar com um cuidado suficientemente bom, e o holding materno torna-o apto a usar a motilidade em favor das experiências do id. Aqui, a força vital motora fusiona-se ao potencial erótico, e todo o conteúdo fusionado é satisfeito pela gratificação instintiva. Assim, o movimento parte do indivíduo em direção ao ambiente - e não o contrário -, podendo satisfazer a necessidade e ao mesmo tempo descobrir e redescobrir o meio. No que tange à parcela de motilidade não-fusionada aos instintos, ela será usada para fins meramente motores, ameaçando o bem-estar caso não o faça. Neste ponto, entra em cena a necessidade de haver uma oposição do ambiente, que transforma o gesto impulsivo motor em agressividade potencial. Neste primeiro padrão, que é o mais saudável de todos, o indivíduo poderá desfrutar da busca pela oposição adequada.

No segundo padrão, o ambiente se impõe ao indivíduo, de modo que o movimento vem de fora para dentro, configurando-se como uma intrusão que leva o bebê a reagir. Aqui, a descoberta do ambiente através da motilidade deixa de ser uma experiência espontânea do indivíduo, e o que temos é uma série de reações à intrusão, em que a motilidade torna-se parte das reações. Neste caso, a existência pessoal só será possível através do retraimento à quietude.

No terceiro e mais extremado padrão, a intrusão é tão intensa que não resta mais nem um lugar onde se possa exercer alguma existência pessoal, a não ser através da criação de um falso self que virá ocultar e proteger o self verdadeiro:

...O 'indivíduo' desenvolve-se então mais como uma extensão da casca que como uma extensão do núcleo, ou seja, como uma extensão do ambiente invasor. O que resta do núcleo permanece oculto, por vezes a ponto de não ser encontrado nem mesmo através da mais profunda análise. (...). O verdadeiro eu está oculto, e aquilo com que temos de lidar clinicamente é um complexo falso eu cuja função é manter 
o verdadeiro eu escondido. (...). A queixa do paciente é de um sentimento de inutilidade. (Winnicott, 1950-55: 297-8)

Neste caso, o indivíduo só vivencia sua motilidade numa situação de dependência e submissão à intrusão ambiental, e a agressividade só pode se expressar enquanto defesa, em termos de agressão reativa (Rodulfo, 2009). A intrusão por excesso de oposição acaba trazendo consequências à fusão dos potenciais agressivos e eróticos, que permanecem desfusionados um do outro, "...ficando a agressividade solta, cindida, o que faz com que se torne destrutiva e uma ameaça social.” (Lejarraga, 2012, p.56).

Este é o caso dos pacientes fronteiriços que, constituídos num ambiente que não pôde manejar sua agressividade com a oferta de uma oposição suficientemente boa, capaz de favorecer a diferença entre o interno e o externo, frequentemente atuam e dramatizam suas forças agressivas no mundo externo, “...levando a expressão dessa agressividade a assumir muitas vezes o colorido de atitudes anti-sociais." (Garcia \& Damous, 2008, p.123).

De acordo com Winnicott, a fusão pode até ocorrer novamente, mas de modo secundário, pela via da erotização dos elementos agressivos, através de tendências masoquistas e atitudes sádicas compulsivas:

...Aqui o erótico funde-se à motilidade, enquanto na saúde é mais correto dizer que a motilidade funde-se ao erótico. (...). O indivíduo não consegue sentir-se real a não ser quando se comporta de modo destrutivo e impiedoso. (Winnicott, 1950-55 : 299)

Neste sentido, sentir-se real e existindo configura uma conquista que advém da possibilidade de integrar ao ego o somatório de experiências vividas no percurso do desenvolvimento emocional primitivo, incluindo aí a agressividade e seu importante papel de discriminar as realidades interna/externa. Quando, por outro lado, o ambiente não responde satisfatoriamente às necessidades, o indivíduo é levado a buscar outros meios não espontâneos de existir, como é o caso da instauração de um falso self patológico que encobre totalmente o self verdadeiro.

$\mathrm{Na}$ doença ocorre que nesse estágio tão primitivo é o ambiente que se impõe, sendo a força vital consumida em reações à intrusão - e a consequência é o contrário da sólida instauração do $E u$. Em casos extremos acontecem muito poucas 
experiências a não ser através de reações, e o $E u$ não se estabelece. (...). O indivíduo que assim passa a existir será chamado de falso, pois a impulsividade pessoal estará ausente. (Winnicott, 1950-55:303)

Vale dizer que o falso self está sempre presente em algum grau, do indivíduo mais sadio até os casos mais graves. Sua existência se configura em gradações, apresentando-se de forma mais ou menos incisiva conforme o padrão qualitativo ambiental do início do desenvolvimento emocional. No caso mais extremo, em que o padrão ambiental constituiu-se como o padrão das falhas, o falso self oculta completamente o self verdadeiro, dando a impressão de aquele responder pela totalidade da personalidade. Porém, chega um momento em que o falso self passa a demonstrar, todavia, carências essenciais, ao passo que o verdadeiro self permanece num lugar secreto e incomunicável, alheio ao próprio indivíduo. No caso menos grave, o falso self defende o verdadeiro, e este pode ter uma vida secreta, potencial, a despeito das condições ambientais adversas. Num terceiro grau, o verdadeiro self pode emergir em situações favoráveis, caso contrário outras defesas terão de ser organizadas. Mais para o lado da normalidade e na normalidade, respectivamente, ele se funda em identificações e numa polidez que possibilita as relações sociais, nunca capazes de se manter totalmente em função do verdadeiro self isoladamente (Winnicott, 1960b).

Em condições favoráveis, no que concerne ao sentir-se real e existindo através do encontro da agressividade primária com a oposição do ambiente, Winnicott (1950-55) afirma que os aspectos motores e sensoriais são os que mais auxiliam nesta empreitada de individuação pessoal. Sendo assim, os impulsos eróticos são incapazes, por si só, de realizarem tal conquista. Isto porque o componente agressivo está em referência à oposição, atestando a existência de um não-eu, enquanto que o componente erótico está em referência à complementaridade, isto é, àquilo que se encontra amalgamado ao bebê num primeiro momento, não remetendo necessariamente a um outro (Phillips, 2006 [1988]).

O gesto pulsional deve ser satisfeito, mas o bebê precisa encontrar na mãe uma colaboradora - ao mesmo tempo suficientemente outro e suficientemente identificado com ele -, mas não uma cúmplice. O que facilita a agressão necessária para o desenvolvimento é a oposição correta do objeto externo. (...). Assim, é apenas através do componente agressivo que o relacionamento com os outros reais pode existir. (Phillips, 2006 [1988] : 162, 161. Grifo nosso.) 
$\mathrm{Ou}$, em outras palavras, a agressividade, quando não reativa, oferece uma “...abertura à alteridade, muito mais do que se pretendeu cobrir com o termo de libido". (Rodulfo, 2009, p. 148).

Como, para Winnicott, o reconhecimento da externalidade - ou alteridade, como sugere Rodulfo (2009) -, ocorre concomitantemente à conquista da integração do self, podemos pensar que o contato dos elementos agressivos com a oposição do ambiente permite ao bebê começar a definir os seus próprios limites. Desta maneira, atestamos a importância da agressividade para a demarcação das fronteiras entre o eu e o outro, com início em suas raízes primitivas de motilidade, que permite o encontro com o que se configura primeiramente como não-eu. É na continuidade deste percurso, pelo viés da agressividade, que o não-eu vai adquirir o estatuto de objeto distinto-de-mim, chegando assim à conquista do uso do objeto.

\section{4}

\section{O uso do objeto e o relacionamento entre pessoas totais}

Para Winnicott, a capacidade de uso do objeto constitui-se como a conquista do reconhecimento da externalidade com natureza e comportamento próprios. O conceito do uso do objeto (Winnicott, 1969 [1968]) é uma construção teórica original, por um viés nunca antes pensado na teoria psicanalítica, qual seja, o de atribuir à destrutividade um papel crucial na criação da realidade. Se comumente a destrutividade é entendida como uma reação ao encontro com o princípio da realidade, em Winnicott temos uma subversão desta ordem, já que, para o autor, é através da própria agressividade/destrutividade que o princípio da realidade é construído (Winnicott, 1969 [1968]). Assim, tanto a criatividade primária quanto a agressividade/destrutividade têm papel fundamental na criação e no reconhecimento da realidade externa. Nas palavras do autor:

...Na teoria ortodoxa, continua a suposição de que a agressividade é reativa ao encontro com o princípio de realidade, ao passo que, aqui, é o impulso destrutivo que cria a qualidade da externalidade. Esse ponto é central à estrutura de meus argumentos. (Winnicott, 1969 [1968] : 130) 
Na visão de Winnicott, até o objeto ser reconhecido como separado do indivíduo e existindo por seu próprio direito, o infans relaciona-se através do que o autor chamou de "relação de objeto" (Winnicott, 1969 [1968]). A relação de objeto pode ser descrita em função da experiência isolada do bebê, enquanto "fenômeno do sujeito" (Winnicott, 1969 [1968], p. 124), exclusivamente por sua própria perspectiva, logo de modo inteiramente subjetivo. No percurso do desenvolvimento, no que tange à relação com o mundo, há no início a relação de objeto, e, no final, o uso. Por uso, não se deve entender exploração, mas a “objetivização do objeto" (Winnicott, 1968, p. 186), isto é, a capacidade de considerá-lo em sua natureza externa, enquanto parte da realidade compartilhada, tornando possível a relação entre pessoas totais.

Até então, na relação de objeto, o ambiente era tido como um "feixe de projeções" (Winnicott, 1969 [1968], p. 123), já que todos os fenômenos do bebê estavam somente em referência a ele mesmo. Amalgamado ao ambiente, o indivíduo jamais poderia considerar ali um outro que não ele ou parte dele, então imperava a ilusão do controle onipotente sobre todo o seu entorno. Em tal contexto, em função da fusão, colocou-se para Winnicott a questão de o bebê ser o objeto. Mais adiante, com a utilização dos fenômenos transicionais, entrou em jogo o bebê possuir o objeto. No momento do qual tratamos agora, entra em cena a possibilidade de o bebê usar o objeto (Dias, 2012), o que implica o seu reconhecimento como ser independente e autônomo.

Entre a relação e o uso, no entanto, o bebê efetua um movimento indispensável à chegada ao fim do percurso. Este movimento consiste na destruição do objeto subjetivo, que é o que irá abrir margem ao reconhecimento do objeto em sua natureza externa:

....No intervalo, porém, temos a coisa mais difícil, talvez, do desenvolvimento humano; ou um dos mais cansativos de todos os primitivos fracassos que nos chegam para posterior reparo. Entre o relacionamento e o uso existe a colocação, pelo sujeito, do objeto fora da área de seu controle onipotente, isto é, a percepção, pelo sujeito, do objeto como fenômeno externo, não como entidade projetiva; na verdade, o reconhecimento do objeto como entidade por seu próprio direito. (Winnicott, 1969 [1968] : 125)

Neste contexto, o que ocorre é uma espécie de renúncia à ilusão de onipotência, atestada pela destruição do objeto subjetivo, que abre margem ao 
reconhecimento do objeto na realidade compartilhada. O bebê, deste modo, expulsa (Dias, 2012) o objeto para além do âmbito de sua onipotência, tornandose apto a reconhecê-lo como finalmente separado de si próprio. A destruição do objeto subjetivo leva à capacidade de usar o objeto, que por sua vez deve ser “necessariamente real” (Winnicott, 1969 [1968], p.123), incluindo aí “...a sua propriedade de estar sempre ali." (Winnicott, 1969 [1968], p. 124).

Davis \& Wallbridge (1981) entendem o "estar sempre ali" em termos de permanência do objeto, algo intimamente relacionado à sua destruição. Se por exemplo o bebê, ao fechar os olhos, destrói aquela parte do mundo que lhe era visível, ao abri-los novamente se dará conta que aquele mesmo pedaço do mundo permaneceu inalterado, e “...esta não-dúvida contribui para a qualidade permanente da realidade externa.” (Davis \& Wallbridge, 1981, p.85). Evidentemente, a permanência depende de um ambiente propício à continuidade do desenvolvimento, isto é, que mantém o mesmo padrão e não se altera. Neste sentido, a sobrevivência do ambiente à destruição é imprescindível para o reconhecimento de seu caráter externo, independente e real, favorecendo a tarefa do bebê de distinguir as realidades interna e externa.

Neste contexto, Winnicott (1969 [1968]) se refere a uma destruição sem raiva (no anger), não advinda, portanto, de experiências de frustração. Trata-se de uma destrutividade própria à necessidade de o bebê habitar um mundo que não é mais parte de sua projeção, onde há objetos que poderão ser usados pelo fato de serem reais. Uma destrutividade com valor positivo - capaz de trazer alegria pela sobrevivência do objeto -, que leva ao encontro com o mundo enquanto tal, e que por isso é considerada criadora da externalidade.

Quanto à sua fenomenologia, Dias (2012) comenta:

...O bebê, que a esta altura está fisicamente mais forte, começa, por exemplo, a chutar a mãe ou a morder efetivamente o seio; ou esmera-se em desgastá-lo; ou ainda a recusá-lo, observando a reação da mãe; ou, simplesmente, deixando de necessitar dele. (Dias, $2012: 235-6$ )

Quanto à sua natureza, no entanto, a comentadora demonstra ambiguidade ao afirmar que a destrutividade não é instintual, “...embora tenha um apoio nas experiências da impulsividade instintual primitiva, que, neste momento, ainda não foi integrada como parte do si-mesmo...", podendo manifestar-se "de muitas 
formas que vêm, naturalmente, misturadas com agressividades de outra natureza, como a instintual.” (Dias, 2012, p. 235).

Discutindo esta mesma questão de uma posição diferente, Roussillon (2009) afirma que o uso do objeto não se restringe à destrutividade manifesta, mas engloba todo o conjunto da vida pulsional com seu potencial destrutivo, podendo manifestar-se na clínica, inclusive, sob forma de transferência erótica. Assim, a destrutividade tem como origem os "movimentos pulsionais" (Roussillon, 2009, p. 1007), embora não seja correto falar verdadeiramente de pulsão quando o objeto é puramente subjetivo, pois deve haver uma diferença entre objeto e fonte como Freud sugeriu nos Três Ensaios (Roussillon, 2009). Talvez ambos os comentadores considerem que a destrutividade se apoia em impulsos pulsionais ou nas raízes instintivas da agressividade, concordando com Winnicott que as experiências instintivas/pulsionais só poderão ser realmente experimentadas e integradas ao ego quando este estiver diferenciado do ambiente. Ao menos no autor francês, esta é uma leitura que já figurava em escritos seus anteriores (Roussillon, 1999).

Novamente e como sempre, o que mais importa para Winnicott - um autor reservado quanto às questões de ordem pulsional - é a qualidade ou as respostas do ambiente ao receber os ataques destrutivos. O bebê só poderá atestar a realidade do objeto caso este sobreviva - porque pode não haver sobrevivência. Deste modo, numa expressão máxima do valor que confere ao ambiente, a escolha da palavra "destruição" relaciona-se primariamente à possibilidade de fracasso na sobrevivência do objeto:

...Sem esse fracasso, a destruição permanece potencial. A palavra 'destruição' é necessária, não por causa do impulso a destruir, mas devido à susceptibilidade do objeto a não sobreviver, o que também significa sofrer mudança de qualidade, de atitude. (Winnicott, 1969 [1968] : 129)

Assim, vemos que a destruição se relaciona intimamente ao risco de o objeto não sobreviver, sendo este o ponto máximo da teoria do uso do objeto. Por sobrevivência entendemos um ambiente que não retalia, não se altera, não muda de atitude ou qualidade e permanece confiavelmente o mesmo (Dias, 2012). Se, por outro lado, o objeto sucumbir, a potência destrutiva do bebê estará comprovada (Lejarraga, 2012), e não teremos mais que uma nova expressão da 
onipotência. Por esta razão, é a sobrevivência do objeto que atesta sua autonomia para além da onipotência do bebê, conferindo "vida própria e durabilidade" (Lejarraga, 2012, p. 59) a um objeto que era até então subjetivamente concebido. No cerne desta trama, a fantasia tem início, considerando-se que o objeto sobreviveu.

...O sujeito diz ao objeto: 'Eu te destruí', e o objeto ali está, recebendo a comunicação. Daí por diante, o sujeito diz: 'Eu te destruí. Eu te amo. Tua sobrevivência à destruição que te fiz sofrer, confere valor à tua existência, para mim. Enquanto estou te amando, estou permanentemente te destruindo na fantasia' (inconsciente). Aqui começa a fantasia para o indivíduo. O sujeito pode agora usar o objeto que sobreviveu. (Winnicott, 1969 [1968] : 126. Grifo do autor)

Para exemplificar a capacidade adquirida de ser destrutivo na fantasia, Winnicott (1965) traz um exemplo hipotético e contundente, porém esclarecedor de sua posição teórica quanto à agressividade e à destrutividade. Sugere um caso em que alguém entra numa galeria e destrói um quadro de um grande mestre. Esta pessoa, que age de modo anti-social, frente à qual a sociedade terá de se proteger, está sendo menos destrutiva do que outra pessoa que preserva a pintura, usando-a plenamente ao destruí-la repetidas vezes na fantasia inconsciente. Pois, "é o pano de fundo da destruição - na fantasia - que mantém o objeto real e, portanto, disponível para o uso.” (Phillips, 2006 [1988], p. 187).

No primeiro caso, portanto, lidamos com uma destrutividade cuja origem remonta a aspectos imaturos do desenvolvimento emocional, ao passo que, no segundo caso, a destrutividade é aquela inerente às relações objetais,

...e que, na saúde, canaliza-se para a destruição que se dá no inconsciente, na realidade psíquica interna do indivíduo, em sua vida onírica e suas atividades lúdicas, e na expressão criativa. (Winnicott, 1965 : 180).

Em termos intrapsíquicos, sobreviver realiza a importante função de localizar a destrutividade dentro da esfera psíquica daquele que age (Roussillon, 1991). O objeto deve receber a destrutividade que vem ao seu encontro, com sua sobrevivência tornando-a fantasmática e potencial. Se o contrário se verifica, ocorre uma “...'morte’ sobre a estruturação psíquica...” (Roussillon, 1991, p. 151), cujo efeito será a impossibilidade de inscrever a destrutividade no psiquismo enquanto potencialidade, tornando-se destrutividade efetiva. Este é o caso dos 
pacientes limítrofes e psicóticos, cujo “...fracasso repetido da experiência do destruído/criado" (Roussillon, 1991, p.147) leva à "tendência à destruição" (Roussillon, 1991, p.147), algo que se mostra com bastante frequência na clínica. Nas palavras do autor:

\begin{abstract}
...O sujeito experimentou a "realidade" da não-sobrevivência do objeto, essa "realidade" realiza o fantasma de destrutividade e, ao mesmo tempo, faz que ele perca sua localização intrapsíquica, seu caráter potencial. A realidade da nãosobrevivência do objeto realiza uma certa forma de sedução pela confusão entre objeto e fonte - que embaralha os referenciais do dentro e do fora, criando um núcleo de confusão primária. (Roussillon, 1991 : 147-8. Grifos do autor.)
\end{abstract}

Desta forma, o objeto permanece enquistado no campo do narcisismo primário, tornando-se não simbolizável porque não desprendido da esfera pessoal, o que traz implicações clínicas e limitações técnicas junto ao método clássico, interpretativo (Roussillon, 1991; André, 1999). Não foi sem razão que Winnicott (1954; 1955-56; 1969 [1968]) fez uma revisão da técnica psicanalítica para aqueles que não podem fazer uso do objeto-analista, como é o caso dos pacientes borderline, para quem o trabalho analítico deve buscar uma transformação da relação para o uso.

Assim, para os pacientes que não conquistaram a capacidade de ser destrutivos na fantasia - em função das respostas não favoráveis do ambiente -, a destruição surge como característica central, de modo efetivo e atuado (Winnicott, 1969 [1968]). Emerge como algo que não pôde tomar lugar na esfera intrapsíquica, expressando-se reativamente, encenando-se ou presentificando-se em ato.

Por outro lado, quando tudo vai bem, a destruição do objeto subjetivo leva à capacidade de usar o objeto, que se torna objetivamente percebido, possibilitando o discernimento entre as esferas pública e privada (Safra, 1999). Vale ressaltar que, tendo em mente que a objetividade é sempre relativa, em momento algum se está isento de certo grau de subjetividade, “...porque aquilo que é objetivamente percebido é, por definição, até certo ponto, subjetivamente concebido." (Winnicott, 1971b, p. 96).

No fim do percurso de conquista do uso, advêm, portanto, o reconhecimento do objeto externo e a integração unitária do self. $\mathrm{Na}$ visão de Safra (1999), o self é um lugar de encontros que se dão prioritariamente pela 
repetição de determinados gestos que buscam resposta junto a outros seres humanos. Na medida em que tais encontros se realizam, torna-se possível criar no mundo dos homens (Safra, 1999).

No caso dos pacientes borderline, tendo em vista que eles ainda não alcançaram a capacidade de uso do objeto (Lejarraga, 2012) e têm a destrutividade como característica central na clínica (Winnicott, 1969 [1968]; Green, 2002), será que aquilo que alguns autores contemporâneos chamam de ataques ao enquadre (Green, 2010 [1988]; André, 1999; Figueiredo, 2003b; Garcia, 2010 [2007]; Damous, 2012a; 2012b) seria parte de uma agressividade reativa, vivida deste modo porque o indivíduo não pôde experimentar uma destrutividade criadora da realidade externa, portanto estruturante? Mais ainda, será que tais ataques constituiriam tentativas atuadas de passagem para o campo do uso do objeto, instituindo a destruição e sobrevivência do analista como peças-chave para o andamento do processo analítico? Antes, porém, de aprofundarmos esta discussão, será necessário esclarecer o que se entende por casos-limite, compreendendo melhor certas particularidades na constituição subjetiva destes casos que nos levam a construir tal hipótese. 


\section{Os casos-limite: uma leitura greeniana}

Os casos-limite, embora ocupem um lugar privilegiado na literatura psicanalítica contemporânea, carecem de precisão no que concerne à sua definição ou tentativa de delimitação dentro dos parâmetros que orientam os psicanalistas desde os tempos de Freud. O conjunto de fenômenos clínicos presentes nesses casos aponta para um modo de funcionamento psíquico ou uma organização subjetiva diferente das três estruturas inicialmente propostas pela psicanálise, a saber: neurose, psicose e perversão. No entanto, a falta de inserção numa dessas três configurações nosológicas não lhes confere necessariamente um lugar próprio, já que os casos-limite podem apresentar traços das três estruturas clássicas, porém com “...elementos refratários a todas as inclusões fáceis e consensuais" (Figueiredo, 2003a, p.79), trazendo dificuldades diagnósticas ao confundirem-se com vários quadros psicopatológicos.

O termo caso-limite foi anunciado pela primeira vez pela psiquiatria, compreendendo os casos que estavam nos limites da psicose, mais precisamente da esquizofrenia (Green, 1986a). No contexto psicanalítico atual, foi a partir do aprofundamento metapsicológico feito sobretudo por André Green que tais casos começaram a ser pensados como organizações originais nas quais é possível reconhecer “...uma estrutura não somente autônoma mas relativamente estável” (Green, 1990 [1986a], p.12), ou seja, com uma problemática própria, em que a questão central gira em torno dos limites do eu (Green, 1999; Guttieres-Green, 2006). A relevância primordial atribuída ao eu se contrapõe à clínica lacaniana de tradição estruturalista que costuma tomar os casos-limite como uma "psicose não desencadeada" ou "psicose ordinária” (Miller, 2005 apud Rosa, 2009, p. 117).

Ao legado de Green somam-se as contribuições de autores conterrâneos (Roussillon, 1999; André, 1999; Donnet, 1999; entre outros) que compartilham de uma posição teórico-clínica semelhante, especialmente no que concerne às seguintes questões: as fronteiras mal delimitadas nos campos intrapsíquico e intersubjetivo; os aspectos traumáticos na relação com o objeto primário; as angústias suscitadas nesta relação e as manobras defensivas utilizadas para combater o excesso pulsional. Tal construção etiológica tem como ponto de 
partida a transferência na relação com o analista, que embora lance luz sobre o cerne da problemática borderline, pode se apresentar fenomenologicamente de maneiras diversas, causando confusão:

\begin{abstract}
...Compreendo os casos-limites ou a estrutura-limite como uma espécie de estrutura geral que é indeterminada, mas que pode se voltar tanto para o lado da depressão como para o lado da perversão, da toxicomania, da psicose. Parece-me, na verdade, que é como se no interior da estrutura psíquica os núcleos psicopáticos, perversos, toxicomaníacos, depressivos, delirantes, travassem uma luta uns contra os outros, para saber qual deles conseguirá apoderar-se da totalidade da estrutura psíquica no interior do "continente". (...) ...a ausência de uma organização nitidamente estruturada... (...) ...faz com que estejamos diante de um caso-limite como diante de uma espécie de placa giratória, onde o limite de um lado ou de outro está de acordo com a evolução da relação de objeto transferencial. (Green, 1990 [1986a] : 20-21)
\end{abstract}

A indefinição dos casos-limite em função das diversas formas de apresentação sintomatológica dificulta, portanto, sua precisão diagnóstica. Não é sem fundamento que a terminologia utilizada - borderline, estados ou casoslimite, paciente fronteiriço - remete a um sofrimento das bordas, das fronteiras ou dos limites, tais casos ocupando um lugar que é uma “...terra de ninguém, todo um campo cujos limites são vagos." (Green, 1988 [1977], p.80). Por esta razão, Green fundamenta sua pesquisa sobre o próprio território dos limites, na tentativa de construir um aparato metapsicológico que justifique os prejuízos nas fronteiras tanto intrapsíquicas quanto intersubjetivas, conferindo aos casos-limite um lugar específico. A precariedade dos limites internos e externos do eu irão, por sua vez, incidir sobre a clínica, questionando-a de igual modo em seus limites. O que faz com que, no atendimento a estes casos, o método habitual tenha de ser repensado, já que os limites da situação analítica são frequentemente atacados? Será possível uma compreensão da constituição subjetiva do paciente limítrofe que nos auxilie nesta empreitada?

\title{
3.1
}

\section{Breve arqueologia dos casos-limite}

Em psicanálise, os primeiros escritos sobre o assunto datam de aproximadamente 1930, havendo ainda quem considere o Homem dos Lobos (atendido por Freud de 1910 a 1914 e publicado em 1918) como o primeiro caso- 
limite da psicanálise (Green, 1999; 2002). Embora Freud nunca tenha mencionado o termo caso-limite (Green, 1988 [1977]), muito menos teorizado a respeito, seu fracasso clínico com o Homem dos Lobos trouxe mudanças significativas à teoria. Foi justamente neste período que Freud se deu conta que alguns pacientes repetem ao invés de se lembrar, e repetem sob forma de atuação na análise. Embora a repetição ocorra de uma maneira geral no tratamento, sendo a própria transferência uma repetição e uma forma de resistir, nestes casos parece ter havido experiências de suma importância na tenra infância para as quais nenhuma lembrança pode ser de fato recuperada:

Há certos casos que se comportam como aqueles sob a técnica hipnótica até certo ponto e só mais tarde deixam de fazê-lo, mas outros conduzem-se diferentemente desde o início. Se nos limitarmos a este segundo tipo, a fim de salientar a diferença, podemos dizer que o paciente não recorda coisa alguma do que esqueceu e reprimiu, mas expressa-o pela atuação ou atua-o (acts it out). Ele o reproduz não como lembrança, mas como ação; repete-o, sem, naturalmente, saber que o está repetindo. (...). Enquanto o paciente se acha em tratamento, não pode fugir a esta compulsão à repetição; e, no final, compreendemos que esta é a sua maneira de recordar. (Freud, 1914a : 165-6. Grifos do autor).

Daí em diante, a noção de compulsão à repetição operou mudanças fundamentais em todo o escopo teórico-clínico posterior. Até então, um dos objetivos da análise era fazer o paciente lembrar o evento traumático recalcado, tornando consciente o inconsciente, desfazendo os sintomas. Porém, viu-se que a rememoração ou tomada de consciência não era possível em todos os casos, nem garantia o desaparecimento do sofrimento, havendo ainda forças que atuavam de modo contrário à cura. Havia, deste modo, resistências intransponíveis nos casos julgados por Freud como definitivamente intratáveis pela psicanálise.

Assim, a constatação clínica da compulsão à repetição em 1914 prenunciou o descentramento do princípio do prazer enquanto balizador do aparelho psíquico, abrindo caminhos para a formulação do conceito de pulsão de morte em 1920, com a repetição de experiências desprazerosas. O ponto alto desta constatação clínica é representado pela reação terapêutica negativa (Freud, 1923), em que o paciente se opõe aos progressos do tratamento através de uma piora ou intensificação do sofrimento, prevalecendo a doença em detrimento da vontade de se curar. A postura de permanecer doente encontra suas raízes no sentimento de culpa inconsciente e na necessidade de punição, e para o analista é onde o método 
habitual da interpretação das resistências encontra seus maiores obstáculos (Freud, 1923).

A mudança no cerne da teoria freudiana - com os novos conceitos de compulsão à repetição, pulsão de morte e reação terapêutica negativa - abriu margem para se pensar os pacientes a que Freud denominou de "não-neuróticos" (Freud, 1920, p. 147), dentre os quais podemos alocar atualmente os chamados casos-limite. $\mathrm{Na}$ obra freudiana, no entanto, certas resistências clínicas provenientes de um funcionamento psíquico para além do princípio do prazer foram tidas como intransponíveis e intratáveis pelo método analítico, logo a psicanálise seria, para estes pacientes, uma terapêutica ineficaz, devendo aplicarse somente aos casos de neurose clássica (histeria, neurose obsessiva, fobia).

A neurose, segundo Green (1999), está fundada na lógica desejante, através da satisfação alucinatória do desejo inconsciente, veiculado pela atividade representacional. Nos casos-limite, esta lógica é substituída pelo vigor da moção pulsional e pela tendência à atuação e à descarga. Sendo assim, o alívio da tensão no aparelho psíquico opera não mais em função do aumento do prazer/ diminuição do desprazer, mas em busca de uma manutenção mínima da "ligação psíquica primária" (Green, 1999, p.52), isto é, do asseguramento dos limites psíquicos mais do que a satisfação pulsional (Garcia, 2010 [2007]). Assim, diferentemente de uma lógica que opera em consonância com o sonho, o recalque, o desejo e a representação, e a que Green (1999) chamou de lógica da esperança, nestes casos o que vigora é a lógica do desespero, onde imperam a clivagem, a depressão e o recurso a ações extra-representacionais, que curto-circuitam a atividade elaborativa:

\begin{abstract}
...a partir do momento em que Freud introduz o modelo da atuação, da descarga, da repetição, o modelo do ato vai entrar na psicanálise como ameaça para a elaboração psíquica. (...). O que vemos aparecer então nesta ocasião é que a representação, contrariamente ao sistema anterior, não é mais um dado, ela é resultado de um trabalho. É bem o que nos ensina a clínica contemporânea. Eu digo, por minha parte, que não é legítimo falar de desejo frente a certos pacientes, porque o que domina é esta tendência a excitar a pulsão em direção à descarga e à repetição, considerando que estes processos curto-circuitam a elaboração psíquica, representada no sistema anterior pelas representações e pelo desejo (Green, 1999 : 44; 52. Tradução nossa).
\end{abstract}

Neste sentido, Green supõe ser possível, já em Freud, encontrar diretrizes que nos orientem no campo dos casos-limite, no que concerne à primazia da 
atuação em detrimento da rememoração, da descarga pulsional no lugar da simbolização. No entanto, é com Ferenczi que vemos o nascimento de um novo paradigma (Green, 1999; André, 1999), sobretudo no que perpassa suas modificações no enquadre analítico, seguidas das novas formulações a respeito do trauma. Embora as inovações clínicas ferenczianas tenham provocado controvérsias no meio psicanalítico da época, especialmente a elasticidade da técnica (Ferenczi, 1928), é a partir de Ferenczi que se abre um campo teórico e clínico de grande utilidade, matriz de onde se deriva o pensamento da Escola Inglesa.

A primeira aparição dos termos borderline ou em psicanálise remonta a Adolf Stern (1999 [1938]), embora ele alocasse este "grupo limítrofe” (p. 159) dentro do campo das neuroses. As heranças de sua descrição extremamente clínica, no entanto, podem ser vistas atualmente em diferentes autores empenhados em semelhante tarefa. São consideradas as questões narcísicas demasiadamente importantes nestes casos, numa etiologia que remete a fatores anteriores ao Édipo. Ao que tudo indica, o investimento narcísico foi escasso, redundando em aspectos clínicos que refletem a imaturidade dos processos psíquicos; as projeções intensas, dificultando o reconhecimento da origem interna da angústia; as dificuldades no teste de realidade; mudanças bruscas de atitude perante o analista e uma sensibilidade enorme e supervalorização do que é dito por ele; demandas de amor e reações terapêuticas negativas frequentes; entre outros.

Em tal contexto, o tratamento invoca “...algumas modificações da técnica psicanalítica" (Stern, 1999 [1938], p. 169), em que será necessária uma adaptação ao paciente, ao menos no tratamento da transferência que repousa sobre bases demasiadamente imaturas. Após atravessada esta fase primordial, só enfim o tratamento poderá alcançar as questões relacionadas ao Édipo e à castração.

Na sequência, Helene Deutsch (1942) descreveu o que ela chamou de pacientes com distúrbio de personalidade “as if”, nem neuróticos, nem, psicóticos, com particularidades no campo dos afetos e das relações com o mundo externo. Estes pacientes, embora tenham relativo sucesso na vida social e profissional, dando a impressão de completa normalidade, carecem de vínculos afetivos e investimentos objetais significativos. Toda a relação com o mundo peca em genuinidade, e as relações são mantidas através de identificações que alcançam 
níveis miméticos em função da grande adaptação ao ambiente. A estrutura egoica conta com uma enorme plasticidade e adesividade, e a aderência a certos grupos ou relações - vale dizer, escorregadias - sugerem uma tentativa de preenchimento do vazio interno com conteúdos que vêm prioritariamente do mundo externo. O empobrecimento afetivo faz com que as emoções ganhem uma expressão não mais do que formal: “...É como a performance de um ator que é tecnicamente bem treinado mas a quem falta a faísca necessária para fazer suas interpretações verdadeiras à vida." (Deutsch, 1942, p. 303).

Num tratamento psicanalítico, os resultados terapêuticos podem ser quase inalcançáveis no encontro com este paciente, cuja descrição caberia perfeitamente no protagonista do filme "Zelig", de Woody Allen.

Em 1967, Otto Kernberg tenta circunscrever as especificidades dos pacientes borderline ao fazer um apanhado de formulações de autores ligados à Escola Inglesa e à Psicologia do Ego. Sugere que tais pacientes possuem uma singularidade etiológica e estrutural, ainda que tendo como referência sua localização entre a neurose e a psicose. A "organização de personalidade borderline" (Kernberg, 1967) repousa, sobretudo, sobre uma fraqueza egoica que pode, por vezes, desvanecer as fronteiras eu-outro; induzir regressões a estruturas cognitivas primitivas, prevalecendo o pensamento em modo de processo primário; sendo predominante o mecanismo de defesa da clivagem. No campo dos fenômenos, a organização borderline pode adquirir características diversas, através de sintomas neuróticos múltiplos, mas também com episódios psicóticos breves. Kernberg (1967) chama atenção ainda para o excesso de impulsos agressivos nestes pacientes, veiculados por uma agressividade pré-genital.

\section{2}

\section{A metapsicologia dos limites}

Na psicanálise contemporânea, André Green é um dos autores mais voltados para o estudo da problemática limítrofe, atentando para os limites da analisabilidade (Green, 1988 [1975]) impostos não só pelas particularidades dos novos pacientes que a psicanálise se propôs a receber, mas também pela insuficiência no cerne da teoria e prática analíticas clássicas para a compreensão e tratamento destes casos. 
Como forma de operar mudanças na clínica atual, superando inclusive posições teórico-clínicas um tanto cristalizadas, Green propõe uma interlocução entre a teoria pulsional freudiana e a teoria das relações de objeto, tornando-as complementares para o estudo da constituição subjetiva de uma maneira geral e, especialmente, para a compreensão clínica das patologias que mais desafiam o trabalho analítico. Green estuda a fundo a teoria das representações e o trabalho do negativo, em consonância com as vicissitudes do objeto no interjogo relacional, com o objetivo de construir um aparato metapsicológico que fundamente a hipótese de que a estruturação dos casos-limite repousa sobre fronteiras mal construídas.

Ao afirmar que estes casos se encontram num território de fronteiras vagas (Green, 1988 [1977]), o autor é levado a indagar sobre a natureza destas fronteiras, e seu ponto de partida é sugerir que o limite seja tomado em psicanálise como um conceito metapsicológico (Green, 1982; 1990 [1986a]). Neste sentido, o limite auxilia a pensar a territorialidade das fronteiras em termos não somente tópicos, mas também dinâmicos e econômicos. Tomar a fronteira como um espaço dinâmico é fundamentá-la não somente a partir de sua função princeps de separar duas partes distintas, mas considerá-la, ela própria, um espaço vivo, que comporta movimentos, passagens e transgressões, e que pode ainda se deslocar, por se tratar justamente de um espaço animado. No aspecto econômico, no âmbito das trocas, as quantidades de excitação podem atravessar determinados espaços, ficar retidas ou ser distribuídas em investimentos laterais, estando as fronteiras, portanto, atravessadas também pelo fator quantitativo. Assim, o limite enquanto conceito metapsicológico é tomado como ponto de partida para discutir a questão das fronteiras, sobretudo no âmbito intrapsíquico:

...A meu ver, nos casos-limites não se trata simplesmente do problema dos limites do ego, mas também da desorganização dos limites no interior do aparelho psíquico, isto é, da importância de mecanismos que acarretam tanto esclerose e rigidez entre as diferentes partes do aparelho psíquico e não apenas na relação do ego com o objeto como, também, da permeabilidade excessiva entre o ego, o id e o superego, o que leva a conceber o limite como um conceito suscetível de nos ajudar na compreensão da psicopatologia dos casos-limites. (Green, 1990 [1986a] : 13)

No que diz respeito aos limites entre $e u$, isso e supereu, Freud já havia anunciado, nas Novas Conferências Introdutórias (1932-33), que as fronteiras 
entre as instâncias psíquicas não são rigorosamente delimitadas como num mapa geográfico (Green, 1990 [1986a]). Mais próximo de uma pintura moderna em que as tintas na tela se fundem ou se sobrepõem, de igual modo as fronteiras do aparelho psíquico são variáveis e modificáveis num mesmo indivíduo, podendo inclusive apagar-se momentaneamente, dependendo das vicissitudes do circuito pulsional. A própria pulsão, por excelência, sempre foi tomada como um “conceito-limite" (Green, 1990 [1986a], p.16) entre o psíquico e o somático, atravessando barreiras ou deslocando fronteiras que se tornam animadas porque investidas pulsionalmente. Diferente do que poderia ser tomado como um espaço morto, as fronteiras se transformam num território vivo onde poderão se efetuar as diversas trocas necessárias para o bom funcionamento do aparelho psíquico.

Partindo do pressuposto que a pulsão tem origem no somático e é incognoscível por si só, seu representante psíquico atravessa a barreira somatopsíquica e adentra o psiquismo com uma exigência de trabalho, em sua busca imperiosa por satisfação. No primeiro território, o inconsciente, o representante psíquico da pulsão se liga a um representante de coisa preexistente, referente ao registro de uma experiência que outrora trouxe satisfação. A pulsão é pura tensão quando não vinculada, e é a partir desta primeira ligação - mais conhecida como realização alucinatória do desejo - que terão origem o afeto e o representante-representação, este investido pela pulsão e de caráter deslocável, transformável, futuro possibilitador da transferência na clínica (Green, 1990 [1986b]). O representante-representação, no entanto, continua insatisfeito e tentará passar para o território do consciente. Antes, porém, ele encontrará com a força do recalque na barreira do pré-consciente, onde terá de se disfarçar, se condensar, se transformar a fim de atravessar a fronteira. Alcançando finalmente o consciente, o representante-representação irá se ligar à representação de palavra, possibilitando a linguagem e a formação dos processos secundários, o afeto se mantendo sempre presente.

Os processos secundários permitem que uma mensagem seja dirigida ao objeto/ mundo externo através da linguagem, porém são os processos terciários (Green, 1982; 1990 [1986b]) que possibilitam o trânsito entre os processos primários e secundários e a comunicação entre o dentro e o fora (Green, 1982). Assim, é na confluência de duas linhas, uma vertical, dividindo o interno e o externo (eu/outro, intersubjetiva), e uma horizontal, no próprio sujeito, dividindo 
os sistemas Pcs-Cs/Ics (intrapsíquica) que serão construídos os processos terciários enquanto processos de pensamento (Green, 1982), sem os quais não há análise possível (Green, 1990 [1986b]).

No percurso que parte da pulsão em sua origem somática até o objeto, a fronteira que separa o psiquismo do mundo externo é a do pára-excitação, onde se dão as trocas que são da ordem da ação e da percepção. $O$ caminho inverso, que parte do objeto e se dirige ao psíquico também pode ser, todavia, considerado. É o caso das teorias das relações de objeto que têm início no solo da experiência transferencial/contratransferencial para daí deduzirem os processos psíquicos subjacentes (Green, 1990 [1986b]).

Ao passo que a consideração do percurso que vai do intrapsíquico até o mundo externo torna a psique analisável, decomposta em partes, transformável, recombinável, o percurso que parte do intersubjetivo traz a vantagem de centrar-se no âmbito da experiência, porém com a desvantagem de não se aprofundar na esfera do funcionamento psíquico e no trabalho do inconsciente. De todo modo, considerando que a psicanálise é uma ciência dialética e “...um movimento não é concebível sem o seu contrário" (Green, 1990 [1986c], p.50), o mais interessante é a consideração do psiquismo como uma “...formação intermediária no diálogo entre o corpo e o mundo" (Green, 1990 [1986c], p. 51), que no entanto pode estar prejudicado nas relações com os limites tanto intrapsíquicos quanto intersubjetivos.

Na leitura de Candi (2010), em casos favoráveis, o funcionamento psíquico forma "vínculos de correspondência" (Candi, 2010, p.115) entre suas diversas produções, estabelecendo relações “...que ao mesmo tempo preservam alguma semelhança e proximidade, mas também permitem a distância e a diferença, possibilitando assim a transformação das formações psíquicas." (Candi, 2010, p.115). Os vínculos permitem um trânsito entre as diferentes produções do aparelho psíquico que se correspondem em termos tanto de oposição quanto de colaboração, como é o caso, por exemplo, da tradução do conteúdo manifesto em conteúdo latente; do sonho em realização alucinatória de desejo. Vemos, neste caso, um aparelho psíquico onde as funções de ligação que se efetuam sob o primado de Eros estão em pleno funcionamento, configurando aquilo que Green (1988) chamou de narcisismo de vida enquanto ligação, investimento significativo e função objetalizante. 
Nos casos-limite, por outro lado, as relações de correspondência entre as formações psíquicas encontram-se prejudicadas, daí os efeitos de "esclerose e rigidez" (Green, 1986a, p.13) que cerceiam a comunicação entre as diferentes esferas do aparelho psíquico. A não relação entre as produções psíquicas traz consequências à atividade de ligação, incorrendo nos percalços do narcisismo de morte (Green, 1988) enquanto desligamento e função desobjetalizante. Aqui, o trabalho de simbolização e a aquisição de sentido encontram sérias dificuldades, impondo barreiras ao trabalho analítico que pressupõe a transposição de espaços psíquicos com vistas à elaboração e a transformação de defesas rígidas.

Nas estruturas com as quais estamos lidando é muito difícil estabelecer as conexões internas da simbolização, porque os diferentes tipos são usados como "coisas" (Bion, 1962, 1963). Os sonhos, longe de constituírem um objeto da realidade psíquica vinculada ao corpo (Pontalis, 1974) e de limitar um espaço pessoal interno (Khan, 1972c), têm uma função evacuadora. As fantasias podem representar uma atividade compulsiva destinada a preencher um vazio (Winnicott, 1971) ou são consideradas fatos (Bion, 1963). Os afetos têm uma função representativa (Green, 1973) e as ações já não mais têm o poder de transformar a realidade. No melhor dos casos, servem para assegurar uma função comunicativa, mas, com maior frequência, aliviam a psique de uma quantidade intolerável de estímulos. (Green, 1988 [1975] : 57-58)

Neste caso, estamos às voltas com um psiquismo cuja excitação não atravessa os limites internos enquanto territórios que possibilitarão determinadas trocas; ao contrário, o representante da pulsão atropela os filtros, indo diretamente do somático para o mundo externo, como é o caso da atuação. De modo inverso, no caso das psicossomatoses, a excitação não adentra o consciente e é devolvida ao soma (Green, 1990 [1986b]).

É no contexto da emergência do irrepresentável que a segunda tópica é criada por Freud (1920), em que a representação não é mais considerada um dado, mas resultado de um trabalho (Green, 1990 [1986b]). Aqui, os processos terciários encontram-se prejudicados, daí os problemas referentes ao pensamento na clínica dos casos-limite, expressos sobretudo pelo “...sentimento de se ter a cabeça oca, de um buraco na atividade mental, incapacidade de se concentrar, de recordar, etc." (Green, 1988 [1975], p. 48).

A impossibilidade de pensar deixa o campo aberto à pulsão de morte e ao desejo de destruição, havendo duas saídas possíveis a partir daí: ou o representante psíquico destrutivo se liga à representação de coisa e se expressa em 
forma de ódio ou destruição passíveis de análise ou transformação, ou o representante psíquico destrói a representação de coisa e a própria capacidade representacional, rompendo os vínculos via destrutividade e desinvestimento, incluindo aí as relações com o objeto tanto interno quanto externo (Green, 1990 [1986b]).

...Mas enquanto vocês tiverem a possibilidade de pôr em relação o representante psíquico com o representante de coisa, estarão lidando com um paciente muito agressivo... Mas isso é algo que faz parte da nossa profissão... Suportar isso e analisar... Não apenas suportar e analisar, mas como dirá Winnicott, se o paciente não experimentar o ódio, em toda a sua extensão, na transferência, ele não colocará nunca seu objeto fora dele, seu objeto permanecerá interno e continuará a persegui-lo de dentro. (Green, 1990 [1986b] : 58)

Assim, é neste mesmo contexto - de impasses clínicos com o paciente fronteiriço - que o setting é pensado por Green (1990 [1986a]) em função da metapsicologia dos limites. Na verdade, a busca por uma compreensão metapsicológica dos casos-limite está intrinsecamente ligada às manifestações clínicas que se expressam, sobretudo, no encontro com o setting enquanto "...um dos representantes dos limites" (Candi, 2010, p.113), que por sua vez será questionado em suas fronteiras e condições de possibilidade assim como de exercício do analista. Nas palavras de Green (1982):

O enquadre não determina somente as condições de um espaço de trabalho, ele modifica a economia dos limites. A clausura que ele instaura coloca em tensão os limites entre analisando e analista. Ele pressiona o analisando a reestruturar sua identidade que a intensidade das trocas ameaça e a vigiar constantemente as fronteiras de sua psique contra a invasão interna (pelas pulsões) ou externa (pelo objeto), os dois se confundindo por vezes. (Green, $1982: 272$ )

De antemão e em todo caso, numa perspectiva mais geral do setting, Green (1990 [1986a]) afirma que seus limites estão ali para suscitar a transgressão, já que tanto paciente quanto analista não conseguirão mantê-los. O paciente em algum momento faltará à sessão ou atrasará os honorários, e o analista, por sua vez, poderá se defrontar com alguma eventualidade que o impedirá de receber o paciente num dia específico. Embora as transgressões se efetuem em algum momento e de um modo ou de outro, o setting ali se mantém, feito paradoxalmente para induzir a experiência da transgressão e ao mesmo tempo 
impedi-la ${ }^{7}$, com seu conjunto de regras que deverão ser seguidas e que instaura algo da ordem de um terceiro ou de uma lei que está acima de ambos. Nas dinâmicas da situação analítica de separação e reencontro vivenciados a cada fim/início de sessão é que se poderão ter notícias da relação estabelecida com os limites dentro/fora, interno/externo, através da própria delimitação do espaço analítico:

...É justamente por ser o setting definido como limite que com respeito a essa ação de delimitação da análise vamos poder avaliar as relações que se passam entre o "dentro"e o "fora" da análise. Pois o interesse desse limite, o interesse de todo limite, é não somente delimitar dois espaços, mas sobretudo ver quais serão as passagens, as transgressões que poderão ocorrer de um espaço para outro, e nos dois sentidos. (Green, 1990 [1986a] : 19)

Além das demarcações contratuais estabelecidas por Freud (1913) que se mantêm até hoje e que funcionam como limites no sentido de uma moldura dentro da qual o processo irá se estabelecer, para Green o próprio processo vê-se às voltas com a questão dos limites, sobretudo no que diz respeito à regra da associação livre. Esta invoca a abolição de um limite, da censura moral e racional, revelando a "loucura potencial do indivíduo" (Green, 1990 [1986a], p.20) ou sua "loucura privada" (Green, 1990), ameaçando a integridade psíquica e narcísica. Ao desfazer a trama da lógica e da razão, a associação livre permite a emergência do ilógico, do infantil e do arcaico num espaço polissêmico (Green, 1990 [1986a]; 2008 [1995]) que pode ser concebido de diferentes maneiras, mas cuja característica principal é a de exercer sua "função de limite" (Green, 1990 [1986a], p.22) em relação à dinâmica psíquica (Green, 1988 [1975]).

Neste ponto, a metapsicologia dos limites no que tange ao funcionamento psíquico se entrecruza com as questões referentes ao setting analítico não somente no sentido de atualizar o tipo de relação estabelecida com a delimitação de espaços atravessados por uma fronteira, mas também por fornecer subsídios para o trabalho de simbolização, favorecendo a atividade representacional. Foi a partir dos prejuízos verificados, aliás, na construção de representações, evidenciados por uma relação transferencial conturbada que Green (1988 [1975]; 2010 [1986; 1988]) aprofundou-se em seus estudos acerca da dupla angústia suscitada na relação com o objeto e do trabalho do negativo em sua função de constituir um

\footnotetext{
${ }^{7}$ Tal como a dupla função do objeto primário de revelar e conter a pulsão (Green, 2010 [1988]).
} 
espaço de ausência no psiquismo, fundamental à construção de representações, à formação do pensamento e ao investimento de novos objetos.

\title{
3.3
}

\section{As vicissitudes do objeto e o trabalho do negativo}

Desde o momento em que Green (1988 [1975]) inicia sua descrição da clínica do vazio, característica dos casos-limite, embora ele já considere a importância de se conceber um espaço de ausência no psiquismo como forma de delimitar as fronteiras psíquicas e construir representações, é somente alguns anos mais tarde (Green, 2010) que a questão da ausência irá se articular com o trabalho do negativo como movimento indispensável para a criação deste espaço interno. É naquele contexto que Green (1988 [1975]) se dá conta dos prejuízos trazidos pelo objeto excessivo em sua presença ou ausência radicais, que interferem diretamente sobre a construção de um espaço potencial no interior do aparelho psíquico.

O espaço da ausência é o que possibilita a representação do objeto primário e, por conseguinte, a representação de objetos substitutos, “...pois, como Freud foi o primeiro a verificar, é na ausência do objeto que a representação dele é formada, a fonte de todo pensamento." (Green, 1988 [1975], p. 48). Em ambos os casos, na presença ou na ausência em demasia, torna-se

\begin{abstract}
...impossível constituir uma ausência. O objeto que está sempre presente intrusivamente, ocupando permanentemente o espaço psíquico pessoal, mobiliza uma permanente contracatexia a fim de combater essa perturbação, que exaure os recursos do ego ou o força a livrar-se de sua carga mediante uma projeção expulsiva. Jamais estando ausente, não se pode pensar nele. De modo inverso, o objeto inacessível nunca pode ser levado para o espaço pessoal ou, pelo menos, jamais de um modo suficientemente duradouro. Assim, ele não pode ter como base o modelo de uma presença imaginária ou metafórica. (Green, 1988 [1975] : 47)
\end{abstract}

Deste modo, o que se configura como um excesso para o psiquismo em constituição prejudica a consolidação de uma estrutura interna capaz de transformar a presença - quando satisfatória - em representação, nas dinâmicas de presença e ausência necessariamente reais, em que se pode pensar no objeto que esteve presente, e que agora se ausenta, porém não mais que o suportável para o bebê. 
Na década de 80, nas suas formulações sobre o trabalho do negativo (Green, 2010 [1986; 1988]), Green (2010 [1986]) recorre ao texto de Freud $A$ Negativa (2007 [1925]), com o intuito de encontrar diretrizes que aprofundem seu estudo sobre a instauração dos limites intrapsíquicos, bem como dos limites entre o eu e o outro.

Vimos com Freud (2007 [1925]) que o Eu-prazer inicial inaugura a delimitação entre o dentro e o fora ao expulsar o desagradável, obedecendo à lógica do prazer/desprazer enquanto balizadora do que deve ser conservado (bom) e expulso (mau). A designação do bom ou mau no interior do aparelho psíquico Freud nomeou de juízo de atribuição, o qual, juntamente com o juízo de existência - que confere existência ou não ao objeto - formam os dois princípios do funcionamento mental.

Antes, porém, da instauração do juízo de existência, o "incipiente trabalho do negativo" (Garcia, 2010 [2007], p. 98) retorna inevitavelmente, e o sujeito tem de lidar com o conteúdo da expulsão. É neste momento que tem lugar o recalque original, inaugurando os limites intrapsíquicos ao dividir o aparelho psíquico nos sistemas $C s / P c s$ e Ics.

O juízo de existência adquire a função que lhe é própria através do teste de realidade, que se faz sentir quando o objeto de satisfação se ausenta. A ausência possibilita a experiência alucinatória, contribuindo para a representação do objeto que esteve presente e trouxe satisfação. Com o teste de realidade, o Eu-prazer inicial (responsável pela atribuição qualitativa bom/mau) dá origem ao Eu-realdefinitivo, possibilitando a diferenciação entre o que pode ser somente imaginado - que está dentro e é, portanto, subjetivo -, e o que pode ser reencontrado na esfera real, pressupondo uma percepção anterior à representação. Seguindo esta lógica, o que inicialmente cabia às moções pulsionais do Eu-prazer inicial (expulsão do desagradável) passa a englobar a atividade do pensamento (representar o que está ausente), contribuindo para a diferenciação entre percepção e representação; entre dentro e fora:

...Assim, a oposição entre o subjetivo e o objetivo não existe desde o início. Ela somente se estabelece pelo fato de que o pensar possui a capacidade de novamente presentificar, através da reprodução no imaginar [Vorstellung], algo que já foi uma vez percebido, isto é, pode-se imaginar o objeto sem que ele precise estar presente no mundo externo. (...). Cabe ainda acrescentar que, ao longo do desenvolvimento, o teste de realidade só entrará em cena quando e se os objetos, 
que outrora trouxeram satisfação, já tiverem sido perdidos. (...). Conforme podemos notar, é novamente uma questão de dentro e fora. (Freud, 2007 [1925] : 149. Grifos do autor.)

Reconhecemos então em Freud a existência da necessidade da ausência do objeto para que sua representação seja formada, e deduzimos que, em contrapartida, o teste da realidade e a função do pensamento ficarão comprometidos caso o objeto não se ausente. É a partir deste pressuposto freudiano da indispensabilidade da ausência que Green (2010 [1986; 1988]) conduzirá sua teorização acerca do trabalho do negativo, sempre destacando seus efeitos sobre a atividade de representação, o pensamento e a delimitação eu-outro.

Dentre as formas de se tornar uma representação inacessível à consciência, ou expulsar/excluir o que é da ordem do traumático, estão os mecanismos de defesa tais como o recalque, a clivagem e a foraclusão. Estas formas de dizer não enquanto diferentes expressões do negativo apresentadas por Freud são retomadas por Green $(2010$ [1986; 1988]) de modo aprofundado, tanto do ponto de vista metapsicológico quanto a partir da teoria das relações objetais. Ele concebe o trabalho do negativo não só enquanto mecanismos de defesa do eu, mas como expressões singulares das três instâncias psíquicas, havendo, portanto, um não do eu, um não do supereu e um não do id enquanto formas de dominar a violência pulsional e se assegurar do amor do objeto (Green, 2010 [1986]). Seu objetivo é discutir o caráter estruturante e também desestruturante dos efeitos da positividade/negatividade do objeto no interior do aparelho psíquico, considerando as respostas do objeto frente aos impulsos pulsionais do sujeito.

No interjogo entre pulsão e objeto, este possui a dupla função de estimular e conter a pulsão (Green, 2010 [1988]), porém no momento em que o eu ainda não se distingue do não-eu, o negativo se efetua através do movimento de "excorporação" (Green, 2010 [1986], p. 292) como trabalho do negativo empreendido pelo id. Aqui, na leitura greeniana a expulsão inicial de Freud (1925) é renomeada excorporação, processo pelo qual o conteúdo desagradável é ejetado “...o mais longe possível” (Green, 2010 [1986], p. 292), antes que haja um objeto identificado como tal, capaz de recolher tais conteúdos. Neste sentido, para Green a noção de espaço vem antes do reconhecimento do objeto. $\mathrm{O}$ autor, no entanto, pondera sobre sua hipótese da excorporação, questionando-se sobre a possibilidade dos conteúdos expelidos desaparecerem no espaço, sem o suporte do 
objeto. Afirma, todavia, que é esta primeira expulsão que inaugura o espaço pessoal, começando a instaurar, consequentemente, a diferenciação eu/não-eu:

...Não é legítimo falar de um não Eu nessa fase, porque o limite Eu-não Eu eu não está estabelecido. O que permite estabelecê-lo são as consequências da expulsão. A expulsão do mau permite a criação de um espaço interno no qual o eu como organização pode nascer para a instauração de uma ordem fundada no estabelecimento de ligações relacionadas a experiências de satisfação. Essa organização facilita o reconhecimento do objeto em estado separado no espaço do não Eu e o seu reencontro. (Green, 2010 [1986] : 292.)

Após o reconhecimento do objeto, este se encarrega de recolher o expulso desagradável, auxiliando na tarefa de descarregar o excesso pulsional, baixando assim o nível de tensão. O objeto substitui, portanto, o espaço indiferenciado, e a excorporação passa a ser uma projeção direcionada ao objeto. A mãe recolhe os conteúdos projetados e acolhe o mau, o agressivo e o destrutivo, metabolizandoos para o bebê:

...(A mãe não acredita mais na maldade do bebê do que na sua).

É essencial para a construção do Eu do bebê que lhe permita dizer sim a si mesmo, que a mãe aceite que ele possa lhe dizer não. Não somente sob a forma de "Você é má", mas às vezes, também, "Você não existe". (Green, 2010 [1986] : 292).

Então, ambos os juízos freudianos de atribuição e de existência são atravessados pelo jugo do negativo, sendo tarefa do eu continuar o trabalho do negativo até então efetuado pelas moções pulsionais do id. De acordo com Green, “...para poder dizer sim a si mesmo é preciso poder dizer não ao objeto" (Green, 2010 [1986], p. 292). Mas do que se trata, exatamente, esta afirmativa?

A excorporação e a projeção são mecanismos psíquicos que expressam a ação do negativo em sua dimensão espacial, contribuindo para a delimitação entre o interno e o externo. Por outro lado, os aspectos temporais configuram uma segunda matriz de igual relevância para o empreendimento do trabalho do negativo, e apontam para a influência de Winnicott sobre o pensamento de Green.

Neste aspecto, é o tempo de resposta do objeto que opera decididamente sobre as possibilidades e os efeitos da atividade negativizante. Quando a resposta se dá em sintonia com as necessidades do bebê - mesmo com um atraso tolerável ou com pequenas falhas assimiláveis -, este toma as aceitações e as recusas do 
objeto como modelo para o recalque, internalizando o sim e o não, e assim o recalque se constitui como a forma mais razoável de lidar com as respostas do objeto.

Por outro lado, se o objeto responde antecipadamente, num tempo anterior às necessidades do bebê, a "onipotência simbiótica" (Green, 2010 [1986], p. 293) ganha espaço, privando o sujeito de dizer não ao objeto e dizer sim a si próprio. As consequências desta dinâmica em que o objeto se torna onipresente perpassam a idealização do objeto materno e a mortificação do próprio desejo. Do mesmo modo, se a resposta do objeto demora mais do que o bebê é capaz de suportar, o desespero e a dor tomam a cena, e o bebê é levado a negar tudo, inclusive a si mesmo. Aqui, os efeitos da ausência excessiva se fazem presentes na baixa tolerância à frustração, na identificação projetiva maciça e na destruição dos vínculos e elos de ligação, numa busca pelo desligamento através de uma exclusão radical (Green, 2010 [1986]).

No momento em que o objeto se faz presente ou ausente em demasia, ele opera precariamente em sua dupla função de estimular e conter a pulsão, deixando de circunscrevê-la de modo a torná-la tolerável para o sujeito:

...Recai-se, nesse momento, em uma espécie de coalescência entre o objeto e a pulsão, e o objeto, ao invés de ser o que torna a pulsão tolerável, é o que, ao contrário, a torna ainda mais intolerável. Sem solução, sem compromisso. (Green, 2010 [1988] : 302.)

Por esta razão, o objeto não deve ser excessivo na presença ou na ausência - o que redundaria numa vivência intrusiva - devendo, ao contrário, se fazer esquecer (Green, 2010 [1988]), configurando um distanciamento que possibilita ao sujeito dizer sim a si próprio neste imbróglio inicial.

O esquecimento ou apagamento do objeto evoca sua qualidade de falível, logo não absoluto (Garcia, 2010 [2009]), vindo transformar-se em estrutura enquadrante (Green, 2002), continente do psiquismo, possibilitando a representação e abrindo espaço ao investimento posterior de novos objetos. Deixar-se esquecer ou apagar é, no entanto e mais uma vez, expressão do trabalho conjunto entre sujeito e objeto nas esferas pulsionais e relacionais, pois embora a mãe deva oferecer um cuidado suficientemente bom em termos afetivos e espaçotemporais, o bebê, por sua vez, deverá ser capaz de negar a ela própria, pela via da 
alucinação negativa enquanto expressão estruturante do trabalho do negativo (Green, 2010 [1977]; 2002).

O fenômeno da alucinação negativa implica na “...não-percepção de um objeto ou de um fenômeno psiquicamente perceptível" (Green, 2002, p. 289. Tradução nossa.), não sendo, no entanto, algo patológico como poderia ser a ausência de representação como quando não se vê a imagem de si refletida no espelho (Green, 2010 [1977]).

Embora a alucinação negativa seja um fenômeno estruturante, existe uma ambiguidade e certa confusão na descrição do conceito, em dois momentos distintos na obra do autor. No anexo de 1977, nomeado A alucinação negativa o fenômeno é descrito enquanto uma "representação da ausência de representação" (Green, 2010 [1977], p.384), advindo daí um "branco constitutivo" (Green, 2010 [1977], p.384) que permite o encadeamento dos pensamentos, pois é preciso descontinuidade para haver articulação. Neste sentido, a alucinação negativa possui a importante "função enquadrante da representação" (Green, 2010 [1977], p.384) ao fornecer os “...limites de um espaço vazio" (Duparc, 2000, p. 60) pronto para ser preenchido com as representações de objetos posteriores. Todavia, em Idées directrices pour une psychanalyse contemporaine (Green, 2002), a alucinação negativa não é mais tomada em sua definição clássica de representação da ausência de representação, mas restrita à esfera perceptiva. Isto porque tal designação poderia trazer confusões entre representação e percepção, parecendo o autor optar pela questão da alucinação negativa na esfera perceptiva.

Ao que tudo indica, a alucinação negativa deve ser entendida pelo viés do esquecimento, de uma presença que pode ser negada pelo fato de não ser percebida, e que por isto mesmo contribui para a construção de um “...vazio internalizado na forma de uma estrutura" (Figueiredo \& Cintra, 2004, p.17). Isto junto a um objeto que responde de uma certa maneira aos movimentos pulsionais do sujeito - deixando-se apagar -, não se mostrando onipresente, mas mantendose “...oculto, em reserva.” (Figueiredo \& Cintra, 2004, p.16).

$\mathrm{O}$ esquecimento do objeto à la Green nos remete à capacidade para estar só descrita por Winnicott (1958), formulação à qual recorremos na tentativa de compreender melhor a questão da alucinação negativa. Para Winnicott (1958), a capacidade para estar só implica necessariamente em estar só na presença de alguém, figurando uma conquista do amadurecimento através da confiança no 
ambiente suficientemente bom. $\mathrm{O}$ ambiente, nesta altura, já foi internalizado enquanto objeto interno bom, e o bebê pode experimentar momentos de nãointegração, relaxamento e devaneios numa "solidão compartilhada" (Winnicott, 1958, p.33). Diferente da reclusão, aqui há a presença do objeto, mas é como se não houvesse; isto é, sua presença existe, mas não é percebida.

A contribuição winnicottiana nos auxilia a compreender a não-percepção do objeto, mas para Winnicott a capacidade para estar só sugere mais uma ideia de continuidade no desenvolvimento do que de ruptura, diferentemente de Green (Garcia, 2010 [2009]). Para Green, é só a partir da ausência conferida pela alucinação negativa que alguma representação do objeto será possível, tratando-se menos de uma introjeção do objeto que de sua transformação num “...elemento estrutural e estruturante do psiquismo" (Figueiredo \& Cintra, 2004, p.17), précondição para as representações futuras, pano de fundo psíquico, “...memória sem conteúdo." (Green, 1983 apud Duparc, 2000, p.60). "Necessariamente falível" (Green, 2010 [1988], p.301), portanto, o objeto que esteve ao alcance da percepção se deixa esquecer, mas continua existindo virtualmente.

Nos casos-limite, o que vemos é uma retorção desta trama, evidenciandose um trabalho do negativo malsucedido. O objeto primário não se fez esquecer, não se deixou “...negar pelos movimentos pulsionais..." (Figueiredo \& Cintra, 2004, p.21), permanecendo como presença maciça no psiquismo, acarretando prejuízos à formação do pensamento e à construção de representações:

\begin{abstract}
...Quando o "objeto absolutamente necessário" não se deixa esquecer - seja porque nunca pôde ser bem encontrado, seja porque não tolera as próprias falhas e as separações, etc. - ele, com seu excesso, produz uma intrusão intolerável e não dá lugar à representação e ao pensamento, à nostalgia e ao desejo, pois em todos estes processos o objeto deve estar ausente. Na presença maciça e contínua do objeto primário, não se dão os processos de simbolização. Proliferam então as saídas nãorepresentacionais como a passagem ao ato, as condutas perversas, os adoecimentos psicossomáticos, etc. (Figueiredo \& Cintra, $2004: 23$ )
\end{abstract}

As frequentes manifestações clínicas não-simbólicas ou extrarepresentacionais tão presentes nos casos-limite remetem, na visão greeniana, a um trabalho do negativo patológico. Para Green, o aspecto destrutivo que acompanha as atuações - em detrimento da associação livre - pode ser entendido como aquilo que se convencionou chamar de ataques ao enquadre (Green, 2010 [1988]), expressão de um trabalho do negativo malsucedido encenado na relação 
com o analista. Deste modo, os ataques ao enquadre, na visão de Green (2010 [1988]), estão intimamente relacionados à impossibilidade de cumprimento do método analítico, em função dos prejuízos representacionais que põem em jogo a associação livre e a interpretação.

Neste ponto, deparamo-nos com uma clínica que se confronta com os prejuízos à formação do pensamento, que é algo anterior às questões referentes ao desejo (Green, 1988 [1975]). No que tange à esfera desejante, temos aqui outro ponto de distinção entre a neurose e os casos-limite. Se se tratasse de neurose, pensaríamos numa problemática girando em torno da questão do desejo, num contexto edípico segundo as formulações clássicas freudianas, com a angústia de castração figurando no primeiro plano. Nos casos-limite, em contrapartida, o Édipo é alcançado (Green, 1988 [1975]; Chabert, 1999), porém o critério de diferenciação das figuras parentais não se baseia na distinção entre os sexos, mas na qualidade da relação que evocam: o bom e o mau; a nulidade e a presença avassaladora. Green (1988 [1975]) denominou "bi-triangulação" (p.46) esta forma de relação triangular que leva em conta a existência de três elementos, mas onde mãe e pai são diferenciados em bom/mau, ausente/dominador. Trata-se, portanto, de um objeto simples que poderia ser dividido em ora bom, ora mau, mas que aqui adquire uma só valência na escala de atribuição bom x mau. A triangulação se constrói, portanto, sobre a relação com dois objetos "simetricamente opostos, que de fato são uma entidade" (Green, 1988 [1975], p.47), isto é, que não fazem que um.

Neste ponto, podemos pensar que o Édipo não é foracluído como na psicose, mas organiza-se segundo a função primitiva do juízo de atribuição bom $x$ mau, tal como descrita por Freud (2007 [1925]) nos primórdios da separação euoutro. A sexualidade não opera como princípio de diferenciação (Figueiredo, 2004), logo o sujeito é balizado por mecanismos primitivos de julgamento, tratando-se, portanto, de...

...uma estruturação psíquica anti-edipica em que a presença de um terceiro é rechaçada, todo o esforço se dirigindo para a manutenção de um encontro diádico do qual se espera uma satisfação plena, embora ele sempre acabe resultando em profunda decepção e em graves pavores. Daí, inclusive, a alternância verificada no paciente borderline entre esperanças irrealistas e estados de desespero e pessimismo profundo. (Figueiredo, 2004 : 516) 
Deste modo, a esperança de fusão - que logo se revela mortífera - ou o vislumbre da separação - trazendo angústias de aniquilamento - não abrem espaço para a angústia de castração inerente ao conflito edípico, que pressupõe a entrada de um terceiro. Assim, seja na leitura da bi-triangulação (Green, 1988 [1975]) ou da estrutura anti-edipiana (Figueiredo, 2004), o terceiro não tem sua entrada efetivada através de sua função primordial, a saber, efetuar a separação entre sujeito e objeto primário. As angústias de intrusão e separação prevalecem à angústia de castração, e se o sujeito permanecer buscando uma fusão com o objeto, esta logo se mostrará mortífera; ou, se por outro lado, vislumbrar uma possibilidade de separação, esta trará uma ameaça de aniquilamento, implicando em questões de vida ou morte. Como Margaret Little (1992 [1990]) explicita em seu relato de análise pessoal com Winnicott, a questão da sobrevivência se torna imperativa na problemática borderline, sendo anterior e muito mais urgente do que qualquer afirmativa de ordem sexual.

Na visão de André (1999), nos casos-limite o objeto primário permanece como objeto único, insubstituível e não-metaforizável, e a separação fica comprometida devido aos prejuízos na capacidade de representação. Para que a atividade representacional seja possível, é necessário que o psiquismo “...se desprenda de seu modelo orgânico para tornar-se a metáfora deste" (André, 1999, p. 76), isto é, que a função vital se insira numa cadeia simbólica, o ato de mamar transfigurando-se por exemplo em expressões de amor, acalento, maternagem, adquirindo algum sentido pela via corpórea - mas indo além dela -, instaurando um processo associativo a nível psíquico.

Vimos com Freud (1905) que as pulsões sexuais se apoiam inicialmente em funções vitais de base orgânica, em zonas erógenas cujo prazer transcende a pura satisfação da necessidade. Secundariamente, a sexualidade se torna autônoma, separando-se da necessidade e buscando uma repetição por si só, de modo auto-erótico. Para que o auto-erotismo - ainda às voltas com as pulsões parciais - se integre em termos de narcisismo, conferindo uma unidade ao sujeito, será necessário "uma nova ação psíquica" (Freud, 1914b, p. 84) capaz de consolidar os limites egoicos (Cardoso, 2010 [2005]), já que “...uma unidade comparável ao ego não pode existir no indivíduo desde o começo; o ego tem de ser desenvolvido" (Freud, 1914b, p. 84). 
Nos casos-limite, que contaram com situações ambientais adversas, persiste uma dificuldade na transformação do objeto da necessidade em objeto de desejo, havendo uma "inquietante flutuação" (Cardoso, 2010 [2005], p.21) na lida com ambos. Neste aspecto, o sujeito se mantém atrelado ao "objeto-coisa" (Cardoso, 2010 [2005], p.25), que se torna insubstituível, "não-descartável" (André, 1999, p. 83). O aprisionamento ao objeto absoluto traz consequências à própria integração narcísica, e também à construção de uma distância eficaz entre o eu e o outro. Nos comentário de Cardoso (2010 [2005]):

...Quando essa "nova ação psíquica" faz-se precariamente, quando as fronteiras narcísicas, egoicas, não se delineiam de maneira suficientemente clara ou plástica, o espaço fronteiriço entre o eu e o outro (externo-interno) - espécie de espaço de trânsito entre os dois campos - tende a permanecer demasiadamente estreito. (Cardoso, 2010 [2005], p. 19).

Deste modo, o jogo do fort/da (Freud, 1920) - brincadeira de presença e ausência, início da simbolização - não se faz possível, o espaço transicional encontra-se comprometido (Chabert, 1999), e o desprendimento do objeto ameaça “...um desprendimento propriamente dito" (André, 1999, p. 76). A potencialidade da ausência evoca, portanto, uma questão de morte tanto do objeto quanto de si próprio, em função do amálgama que persiste entre ambos. A mãe, no caso, não pôde ser perdida (André, 1999) - ou esquecida, em termos greenianos -, levando a crer que as frequentes angústias de separação, na clínica, sugerem menos uma ameaça de perda que a impossibilidade da perda (André, 1999; Cardoso, 2010 [2005, 2007], Damous, 2012a), o tratamento analítico tendendo a se confundir com o trabalho do luto.

Para Cardoso (2010 [2005]), embora a assimilação do objeto e a totalização do eu nos casos-limite sejam de fato precárias, a perda impossível do objeto primário não redunda, em última instância, numa indiscriminação entre o eu e o outro, mas numa servidão ao outro:

O objeto - tornado único e funcionando como último recurso - torna-se a única fonte de satisfação, objeto que não é reconhecido como um outro separado de si, ou seja, ele permanece enredado no circuito da fascinação/servidão, desqualificado, portanto, no que concerne aos seus limites, suas fronteiras. (Cardoso, 2010 [2005] : 24) 
De todo modo, se a indiscriminação não é absoluta, a "...experiência de separação ruim" (Damous, 2006, p.91) torna as fronteiras entre o eu e o outro no mínimo porosas, permeáveis. Não que na saúde tais fronteiras sejam estanques, porém o ambiente permaneceu fidedigno e sobreviveu aos ataques, sustentando uma imagem integrada de si, ao mesmo tempo em que assegurou os limites pessoais do sujeito em ascensão.

Nos casos-limite, ao contrário, a "função narcisante dos objetos" (Figueiredo, 2003a, p. 89) não cumpriu sua função de auxiliar no investimento pulsional das fronteiras externas e internas do eu, investimento este determinante para a criação recíproca das realidades dentro/fora. Assim, as fronteiras intrapsíquicas e intersubjetivas permaneceram mal delimitadas, ameaçando ser atacadas caso a separação ou “...superação dos vínculos simbióticos” (Figueiredo, 2003a, p. 89) ameace se efetivar.

Neste sentido, estamos às voltas com um psiquismo que recusa qualquer mobilidade ou mudança, trazendo para a clínica sérios desafios para o campo da simbolização. Em função de o sujeito se manter preso ao objeto único, com a terceiridade dando notícias precárias de sua existência, a interpretação é incapaz de "triangular", isto é, de trazer para a cena analítica algo da ordem de um terceiro que promova um deslizamento simbólico na trama constipada (André, 1999). Para Figueiredo (2004), os "ataques ao terceiro" (p. 516) representam a impossibilidade de lidar com um terceiro elemento que transcenda o caráter simbiótico das relações, o que para Green (2010 [1988]) está intimamente relacionado a um trabalho do negativo malsucedido, que encontra no mecanismo da clivagem sua expressão principal.

Em função dos traumatismos precoces e da fragilidade do envelope narcísico nos casos-limite (Guttieres-Green, 2006), as defesas organizadas para combater o excesso pulsional se dão na tentativa de apartar o conteúdo traumático, excluindo-o e enquistando-o num lugar aquém do acesso representacional. Justamente pelo fato de a problemática limítrofe repousar sobre experiências traumáticas que não puderam adquirir uma representação - diferentemente da neurose, em que o mecanismo de defesa predominante é o recalque -, nestes casos o que vemos é uma preponderância do mecanismo da clivagem, cujos efeitos sobre o psiquismo são bem mais radicais. No recalque, embora haja uma dissociação entre afeto e representação devido a uma incompatibilidade da vida 
pulsional com as exigências do ego/superego ou do mundo externo, os elos de ligação permanecem intactos, possibilitando uma substituição ou recombinação entre afetos e representações. Trata-se, portanto, de uma transformação dos elos de ligação, e a energia psíquica permanece ligada. Na clivagem, os elos são alterados ou destruídos, e o conteúdo psíquico sofre uma exclusão radical, permanecendo enquistado no psiquismo, num lugar inacessível à consciência em termos representacionais. O eu fica repleto de núcleos isolados que não se comunicam entre si, como se fosse um grande arquipélago composto por ilhas que não se unem com coerência ou coesão. A falta de coerência entre as partes acarreta uma paralisia do pensamento, tornando-se impossível construir representações, dificultando ainda a função de julgamento do eu (Green, 1988 [1977]).

Vale explicitar que aquilo que se dá no âmbito intrapsíquico está necessariamente interligado às vicissitudes do objeto, havendo, portanto, uma face interna e uma face externa de um mesmo objeto. Neste sentido, Green (1988 [1977]) compreende a clivagem nos casos-limite como uma resposta do sujeito frente “...à atitude do objeto, que pode ser dupla” (Green, 1988 [1977], p.83), isto é, que instaura uma vivência da ordem do traumático em função de uma presença ou ausência demasiadas. Por um lado, dá-se uma fusão prolongada e excessiva, e a separação mãe-bebê é dificultada pela falta de referência a um terceiro elemento que auxilie nos movimentos de separação e religação com a criança. Neste caso, o que se vê é uma mãe que evita ou posterga a desadaptação gradual, permanecendo fusionada ao bebê por mais tempo que o necessário. Por outro lado, a ausência de fusão por parte da mãe faz com que a criança se (re)encontre com um "seios em branco" (Green, 1988 [1977], p.83), que por sua vez remete a um estado de vazio. Aqui, sem a experiência da fusão ou esta ocorrendo com muita precariedade, a experiência da ilusão de onipotência (Winnicott, 1945) não ganha lugar, prejudicando os demais processos de constituição do eu e diferenciação eu-outro.

Os dois modos de atitude do objeto suscitam uma vivência pulsional pautada no excesso, trazendo consequências para o âmbito relacional. Neste contexto, certamente traumático - pois, como é sabido desde Freud (1920), o trauma repousa sobre o excesso pulsional -, o recurso à clivagem emerge como uma saída, com o objetivo de não sucumbir totalmente ao objeto, salvaguardando 
ao menos alguma esfera do psiquismo ao manter clivado o que é da ordem do traumático (Roussillon, 1999a).

Para Roussillon (1999a), a clivagem é uma manobra defensiva perante o traumatismo primário existente nas diversas formas de patologias do narcisismo ou sofrimentos narcísico-identitários, incluindo aí os casos-limite. O traumatismo primário remete a uma ameaça narcísica vivida num tempo em que a constituição subjetiva começava a se dar, colocando em xeque a "função subjetivante do eu" (Roussillon, 1999a, p.09), resultando numa "falta $a$ ser" (Roussillon, 1999a, p.13. Traduções nossas.), mais do que uma falta no ser, que já pressuporia um eu estabelecido, de onde poderia vir a faltar algo.

$\mathrm{Na}$ leitura freudiana, a clivagem é o mecanismo fundante da perversão, em que a castração é desmentida, havendo a coexistência de julgamentos opostos na esfera perceptiva (Freud, 1940 [1938a]). O menino percebe que a mãe não tem pênis, mas se recusa a acreditar por medo de perder o seu, criando, por conseguinte, um substituto (objeto fetiche) para o pênis ausente na mãe. No texto freudiano, em certa medida a clivagem está presente também nas psicoses, sendo estendida em seguida (Freud, 1940 [1938b]) para as neuroses narcísicas, como um mecanismo de defesa que abrange o campo mais amplo das alterações do $e u$.

Nos casos-limite, ao invés de ser tomada como clivagem do eu, como no viés freudiano, o mecanismo de defesa se aproxima mais de uma clivagem ao eu (Roussillon, 1999a). Isto porque, nestes casos, a clivagem se distancia daquela baseada no escopo percepção-representação egoico, tornando-se clivagem do que mal pôde se inscrever como experiência do eu, o que exigiria uma atividade representacional que, nestes casos, ainda não se constituiu por ocasião do trauma.

De um lado, a experiência foi "vivida" e então ela deixou "traços mnésicos" de sua vivência e ao mesmo tempo, de um outro lado, ela não foi vivida e apropriada como tal na medida em que, como o diz Winnicott, ela não foi colocada "ao presente do eu", o que suporia que ela tivesse sido representada. (Roussillon, 1999a : 20. Tradução nossa.)

Assim, é mais correto dizer que o conteúdo clivado permanece alheio ao eu, por uma questão de sobrevivência psíquica. Deste modo, é a própria subjetividade que é amputada, dividindo-se numa parte representada e em outra não representável. $\mathrm{O}$ sujeito se desloca de sua experiência subjetiva, e até certo 
ponto “...não 'sente' mais o estado traumático, ele não se sente mais lá onde ele está, ele se descentra de si próprio..." (Roussillon, 1999a, p. 20. Tradução nossa.).

A clivagem, no entanto, é apenas o primeiro recurso de sobrevivência psíquica frente ao traumatismo primário, mas não garante o funcionamento do princípio do prazer, pois os conteúdos clivados permanecem submetidos à compulsão à repetição. Por conseguinte, a ameaça de retorno do clivado é frequente, não sob forma de representação, mas como uma reprodução do próprio estado traumático. O sujeito então lança mão de defesas complementares tais como as tentativas de ligação primária não-simbólica (Roussillon, 1999a) a fìm de dar conta do que volta a ameaçar sua organização narcísica precária e desde sempre ferida. Surgem, então, as saídas sexualizadas tais como o masoquismo ou o fetichismo; as psicossomatoses; as soluções grupais, institucionais ou religiosas; as saídas delirantes/psicóticas e a busca pela neutralização energética. Esta última caracteriza-se pelos não-investimentos objetais capazes de reativar a zona traumática, resultando num maior empobrecimento do eu e aproximando-se daquilo que Green (1988) teorizou como o narcisismo negativo.

Para Green (2010 [1986]), a propriedade clássica da clivagem de fazer coexistir o sim e o não pode se manifestar de duas formas distintas, conjuntiva ou disjuntiva, estando esta última intimamente relacionada a um trabalho do negativo mal sucedido. A conjuntiva é regida por Eros e pode ser pensada em termos de sim e não. Este é o caso, por exemplo, do fenômeno transicional, em que o objeto é criado e encontrado, em que é ainda subjetivo, mas até certo ponto percebido objetivamente, e está localizado na interseção entre o interno e o externo. Por outro lado, a coexistência disjuntiva é a que opera em função da clivagem, que rejeita e exclui sob a égide das pulsões de destruição, prevalecendo a lógica do nem sim, nem não (Green, 2010 [1986]). Neste caso, as funções de ligação encontram-se prejudicadas, daí as frequentes manifestações extrarepresentacionais encontradas numa clínica caracterizada pela destrutividade, pelo desinvestimento, pela tendência à fusão com o objeto e pela identificação com o objeto destruído pela separação. A clivagem em sua forma disjuntiva opera como resultado de um trabalho do negativo malsucedido, que se manifesta em sua forma destrutiva na análise através dos ataques ao enquadre (Green, 2010 [1988]).

Deste modo, o malogro do trabalho do negativo e as dificuldades na separação sujeito-objeto resultam em intempéries no encontro analítico, no que 
este demanda de trabalho psíquico (elaboração) e naquilo que invoca em termos relacionais/transferenciais. Sendo assim, com o objetivo de compreender os ataques ao enquadre nos casos-limite, relacionando-os, por fim, com o uso do objeto em Winnicott (1969 [1968]), será necessário, antes, retomarmos a literatura acerca do enquadre/ setting/ situação analítica, com vistas aos desvios sempre esperados quando se presume um ideal. Ora, se a psicanálise inicialmente propõe a elaboração em detrimento da ação, em que autores podemos encontrar novas contribuições acerca da situação analítica quando as condições ao tratamento se mostram adversas? 


\section{O enquadre analítico: principais contribuições}

O enquadre clínico psicanalítico, embora não tenha sido teorizado por Freud (Green, 1990 [1986a]; Roussillon, 2008 [1995]), pode ser compreendido através das delimitações por ele estipuladas como pré-condições à aplicação do método analítico, desde o abandono da hipnose, na última década do século XIX. De fato, não encontramos nos principais dicionários de psicanálise (Laplanche \& Pontalis, 2001 [1982]; Roudinesco \& Plon, 1998 [1997]) nenhum verbete referente ao contexto analítico, como enquadre, enquadramento, setting, situação analítica, dispositivo analítico, ainda que autores pós-freudianos tenham dedicado maior atenção ao assunto de forma criativa e original. As novas construções se deram principalmente em função do encontro com pacientes difíceis, incluindo aí casos de psicose, borderline e neuroses graves, perante os quais o método clássico se mostrou ineficaz.

No percurso freudiano, foi o conhecimento cada vez mais sofisticado dos processos psíquicos que possibilitou a instauração de um método propício à emergência dos conflitos inconscientes, intimamente relacionados à questão do desejo. Este método foi especificamente construído de modo a facilitar o desenvolvimento da relação transferencial cuja identificação e interpretação possibilitavam a emergência dos conteúdos inconscientes. Estava, assim, sacramentada a articulação necessária entre método e enquadre. Nas palavras de Donnet (2005 [1973]):

...o enquadre é isto que funda o poder da interpretação, e a interpretação, isto que funda a legitimidade do enquadre. (...). Pois, desde então, é porque a interpretação é perigosa que é preciso um enquadre (que a torne benéfica), mas é também porque há um enquadre que a interpretação é perigosa (e então potencialmente eficaz). O enquadre é isto que deve permitir à interpretação ser "boa" e não mais que boa, quer dizer, ao mesmo tempo eficaz e salutar. (Donnet, 2005 [1973] : 91-92. Grifos do autor. Tradução nossa.)

No que concerne à tríade funcionamento psíquico/ enquadre/ método analítico, alguns autores sugerem que a situação analítica tal como construída por Freud seja comparada ao modelo do sonho ou até mesmo baseada na atividade do sonhar capaz de revelar o desejo inconsciente através do encadeamento onírico 
(Lewin, 1955; Khan, 1962; Green, 1988 [1975]; 1990 [1986a]; 2002). Assim, do mesmo modo que o espaço psíquico e o sonho estão contidos dentro de certos limites, sendo regidos por conteúdos inconscientes segundo a lógica desejante (Green, 1988 [1975]), a situação analítica sustenta e contém a fala em associação livre (Freud, 1904) capaz de trazer à tona os conteúdos inconscientes numa sessão conduzida como um sonho em vigília. Aqui, o dispositivo espacial da análise se torna um correlato do espaço do sonho, sobretudo no que concerne à abolição dos polos perceptivos e motores (Donnet, 2005 [1973]; Roussillon, 2008 [1995]). Privilegia-se, através do discurso analítico, o funcionamento mental e a expressão da realidade psíquica desde a manifestação do desejo inconsciente até o desdobramento da "loucura pessoal" (Green, 1990), só passível de ser revelada sob condições favoráveis e específicas.

Com a regra fundamental da associação livre, o paciente, antes submetido ao sono hipnótico, torna-se um "confiante" (Lewin, 1955 apud Khan, 1962, p. 44) do método, ao passo que o analista, cuja tarefa enquanto hipnotizador se iniciava ao empreender o sono alheio, torna-se, por seu turno, um "acordador" (Lewin, 1955 apud Khan, 1962, p. 44), operando “...para despertar um pouco o paciente, ou para fazê-lo um pouco dormir.” (Lewin, 1955 apud Figueiredo, 2011, p. 142).

Na visão de Khan (1962), a situação analítica foi criada a partir da autoanálise de Freud, através da interpretação dos seus próprios sonhos somada ao insight e à empatia com os pacientes em sua experiência clínica. Recriou-se no contexto analítico “...uma ambiência física e psíquica...” (Khan, 1962, p. 42) correspondente ao estado intrapsíquico daquele que sonha, e deste modo o enquadre serviu de ferramenta de pesquisa e de conhecimento da dinâmica intrapsíquica e dos conflitos inconscientes, bem como de instrumento terapêutico para a solução dos conflitos simbolizados e condensados nos sintomas que, por sua vez, representam um “...latente desejo de sonhar...” (Khan, 1962, p.49).

O que permitiu que Freud transformasse sua heroica experiência subjetiva de auto-análise ("esta análise é mais difícil que qualquer outra", 1950a) num método terapêutico foi a sua genial capacidade de abstração, que o levou a recriar, no setting analítico, todos os elementos vitais da situação da pessoa que sonha, de forma que, num estado consciente de vigília, quem está sendo analisado possa, psiquicamente, re-experimentar, por meio de neurose de transferência, os distúrbios psíquicos inconscientes e estados de enclausuramento que distorcem o seu funcionamento de ego e lhe tolhem a liberdade afetiva. (Khan, 1962:41. Grifo do autor) 
Além do setting em si, a situação analítica também engloba, evidentemente, paciente e analista, e é no interjogo entre esses três elementos que se constituem o processo e o procedimento analíticos capazes de conduzir àquilo que Khan (1962) chamou de "sonho bom". Considerando que o sonho é "...o protótipo de toda criatividade psíquica do ser humano adulto" (Khan, 1962, p. 47), o "sonho bom" se desdobra a partir de certas premissas tais como: um ambiente seguro e tranquilo; a confiança do ego para poder se afastar do mundo externo e assegurarse de que este continuará lá quando cessar o desejo de dormir; uma força motriz interna que possibilita o trabalho do sonho e a simbolização; a capacidade de regredir psiquicamente, sobrevivendo aos impulsos caóticos do isso; o relaxamento da barreira repressora do supereu; devendo ser ainda tomados como certos os primeiros estágios de integração egoica, tal como formulados por Winnicott (1945).

Não obstante, deparamo-nos na clínica com pacientes incapazes de ter um "sonho bom", para quem a atividade associativa não conduz a uma atividade simbolizante e tampouco facilita a revelação do desejo inconsciente. Tais pacientes “...não podem usar a situação analítica criativamente” (Khan, 1962, p. 53. Grifo nosso) ou “...não podem usar o contexto como um meio ambiente facilitador" (Green, 1988 [1975], p. 51. Grifo nosso), e deste modo já não é mais possível uma analogia da situação analítica com o modelo do sonho (Khan, 1962).

Nestes casos, dentre os quais se incluem os "fronteiriços" (Khan, 1962, p. 53), o que se expressa na situação analítica leva a crer na existência de uma problemática relativa à integração egoica e à diferenciação do ambiente em termos de self unitário (Khan, 1962). Isto implica na necessidade de mudanças na situação analítica no sentido de o trabalho não mais se pautar na interpretação e na elaboração das resistências via neurose de transferência, até porque muitas vezes não se pode contar com a instauração desta "doença artificial" (Freud, 1914) no tratamento desses casos (André, 2002).

De um modo geral, as variações do método analítico se iniciaram em função das dificuldades surgidas na técnica interpretativa (Donnet, 2005 [1973]) e com o objetivo de ampliar a esfera de alcance do tratamento psicanalítico de modo a incluir os casos difíceis e os casos-limite (Figueiredo, 2011). Assim, se em Freud os casos adequados à psicanálise eram os de histeria, fobia e neurose obsessiva 
(Freud, 1916-17), com os pós-freudianos esta possibilidade se estendeu, sendo Winnicott, na visão de Green (1988 [1977]), o analista, por excelência, dos casoslimite. Antes dele, no entanto, as inovações técnicas de outros psicanalistas já haviam efetuado modificações no enquadre analítico original, ajudando a compor uma clínica mais abrangente: Melanie Klein com o brincar na clínica com crianças; Ferenczi com novas contribuições para a teoria do trauma e a elasticidade da técnica; e Lacan com o tempo lógico e a teoria das psicoses.

As principais contribuições pós-winnicottianas a respeito do enquadre compreendem a situação analítica como campo dinâmico (Baranger, 1961-62) e apontam para a necessidade de análise do enquadre, onde são depositados os elementos mais primitivos - de ordem simbiótica - que, se não trazidos para dentro do processo, permanecerão não analisados num tratamento que jamais terá chegado ao seu alcance mais profundo (Bleger, 1967). Nesta vertente latinoamericana, é a ruptura do enquadre que faz com que os aspectos simbióticos mudos, depositados no não-processo - se manifestem e possam ser analisados, e deste modo a observância às regras torna-se não mais que uma resistência tenaz ou uma expressão do "baluarte" (Baranger, 1961-62, p.151) enquanto aquilo que o paciente evita pôr em jogo no tratamento, a todo custo (Bleger, 1967).

Neste percurso, o enquadre desde Freud como contrato ou convenção será rediscutido fundamentalmente por uma perspectiva winnicottiana, e em seguida segundo as formulações dos Baranger (1961-62) e de Bleger (1967), naquilo que tais autores trazem de mais original ao tema em questão.

\section{1}

\section{As primeiras delimitações do fazer psicanalítico: o enquadre em Freud}

Antes de a psicanálise se fundar como disciplina independente, a hipnose era a forma utilizada para tratar os sintomas histéricos resultantes de uma vivência traumática, servindo de instrumento para se chegar aos conteúdos inacessíveis à consciência, chave para a compreensão do estado patogênico. O médico procurava insistentemente a lembrança almejada, conduzindo e organizando ativamente o caos associativo do paciente, "de fora" (Roussillon, 2008 [1995a], p.101), através 
de seu próprio pensamento; lançando mão, por vezes, da sugestão como forma de alcançar a rememoração ou fazer cessar os sintomas.

No contexto dos Estudos sobre a histeria (Breuer \& Freud, 1895), o método catártico de Breuer consistia em hipnotizar o paciente com o objetivo de se chegar até a lembrança do trauma, provocando a ab-reação (liberação) do afeto outrora suprimido em função do acontecimento traumático. A hipótese era de que o paciente não teria encontrado meios de reagir favoravelmente via descarga do afeto, que foi então desviado, suprimido, dissociado da representação do acontecimento, tendo se tornado um "afeto estrangulado" (Breuer \& Freud, 1893, p. 52). A representação, por sua vez, teria sido esquecida, recalcada (Breuer \& Freud, 1893), permanecendo alheia ao pensamento consciente. A dissociação entre afeto e representação resultava no aparecimento dos sintomas, em sua maioria corporais.

Através do método catártico, a liberação do afeto correspondente à lembrança recalcada ajudava a traduzir o "trauma psíquico" (Breuer \& Freud, 1893, p.41) em palavras. A reação ao trauma, que poderia se expressar sob qualquer forma de ato, foi então substituída pela linguagem nesta técnica que a célebre paciente de Breuer, Anna O., chamou de "talking cure" (Breuer \& Freud, 1895, p. 65) e que vigora até hoje na cena psicanalítica: a cura pela fala, em detrimento do ato. Viu-se que as associações verbais das pacientes histéricas que sofriam de reminiscências (Breuer \& Freud, 1893) - acabavam alcançando as lembranças mais remotas, elucidando vivências marcantes da puberdade e da infância, sobretudo de ordem sexual.

Diferentemente de outros médicos da época, Freud decidiu abandonar a hipnose, principalmente pelo fato de esta desconsiderar o papel relevante da resistência na manutenção dos sintomas. Constatou que muitos pacientes não conseguiam ou não se deixavam hipnotizar, além de ele próprio carecer de habilidades técnicas necessárias ao hipnotizador e, por último, não mais desejar proferir ordens aos pacientes no intuito de fazê-los dormir (Breuer \& Freud, 1895).

Com as novas descobertas acerca do funcionamento psíquico, facilitadas pelo abandono da hipnose - sobretudo no que se refere ao inconsciente com seu modo próprio de funcionamento capaz de estabelecer elos de ligação (Freud, 1911) -, Freud pôde ir relegando ao paciente a tarefa associativa sem pretender 
organizar ou recortar os temas evocados, colocando-se "em reserva" (Roussillon, 2008 [1995a], p. 101), abrindo espaço para o conhecimento da organização interna do paciente. Deste modo, o desenvolvimento do método psicanalítico se dá concomitantemente às novas investigações acerca dos processos inconscientes (Figueiredo, 2011), instaurando um enquadre favorável à elucidação dos processos psíquicos fundamentais à análise, a saber, a transferência e a resistência (Freud, 1914c).

O paciente, por sua vez, adquire a livre expressão de seu discurso através do método da associação livre, próprio da psicanálise e diferente de outros métodos terapêuticos. Assim, a hipnose encontra seu substituto no conjunto de associações inintencionais ou pensamentos involuntários, dentre os quais muitos são postos de lado porque contundentes e perturbadores. A respeito do novo método, encontramos a seguinte descrição:

\begin{abstract}
...sem exercer nenhum outro tipo de influência, [Freud] convida-os a se deitarem de costas num sofá, comodamente, enquanto ele próprio senta-se numa cadeira por trás deles, fora de seu campo visual. Tampouco exige que fechem os olhos e evita qualquer contato, bem como qualquer outro procedimento que possa fazer lembrar a hipnose. Assim a sessão prossegue como uma conversa entre duas pessoas igualmente despertas, uma das quais é poupada de qualquer esforço muscular e de qualquer impressão sensorial passível de distraíla e de perturbar-lhe a concentração da atenção em sua própria atividade anímica. (...). Antes de exortá-los a um relato pormenorizado de sua história clínica, ele os instiga a dizerem tudo o que lhes passar pela cabeça, mesmo o que julgarem sem importância, ou irrelevante, ou disparatado. Ao contrário, pede com especial insistência que não excluam de suas comunicações nenhum pensamento ou ideia pelo fato de serem embaraçosos ou penosos. (Freud, $1904: 237)^{8}$
\end{abstract}

No curso das associações, além do material desdenhado, Freud se dá conta da frequência com que alguns acontecimentos reais são esquecidos, provocando lacunas na memória e deixando certos conteúdos incompreensíveis devido às distorções em suas conexões temporais ou causais. O preenchimento das lacunas é dificultado pelas ideias repelidas por motivos críticos ou morais, e as amnésias são resultado do processo de recalcamento, que por sua vez encontra seu correlato clínico na resistência, já que esta opera como força oposta à restauração das lembranças (Freud, 1904), devendo ser, portanto, convocada e não mais evadida do tratamento:

\footnotetext{
${ }^{8}$ Em 1913 (Sobre o início do tratamento), Freud reconhece o pedido de que o paciente se deite como um vestígio remanescente do método hipnótico.
} 
O processo se transforma: ao invés de transpor e tentar evitar as resistências inconscientes recorrendo à hipnose, elas são convocadas; a investigação deixa que elas venham e entra em contato com elas, e segue em frente; na verdade, deixa-se conduzir pelas próprias resistências, à medida que surgem, em sua busca gradual dos fatores patogênicos que, por sua vez, perdem a relativa simplicidade de um "evento traumático" para serem concebidos de forma muito mais complexa e dinâmica, incluindo conjuntos de fatores da vida de relações do sujeito e suas fantasias, os "complexos". (Figueiredo, 2011 : 138).

Neste ponto, a resistência teve papel fundamental na consolidação da psicanálise como ciência independente, podendo ser considerada sua base epistemológica $^{9}$ ou aquilo que vem confirmar e reafirmar sua aplicabilidade clínica. Em qualquer experiência clínica psicanalítica, a resistência - aliada à transferência - emerge necessariamente, constituindo empiricamente a base a partir da qual serão inferidos os processos intrapsíquicos.

O novo método, vigente até os dias atuais, propõe que o paciente siga com observância à regra fundamental, associando livremente e sem censura, ao passo que o analista, por sua vez, deve escutá-lo com uma atenção flutuante (Freud, 1912a), sem privilegiar de antemão qualquer elemento do discurso do paciente, deixando sua atividade inconsciente funcionar de modo igualmente livre (Laplanche \& Pontalis, 2001 [1982]). Do material bruto das associações, cabe ao analista a interpretação dos elementos inconscientes que se expressam através das resistências nas associações e também através dos sonhos, lapsos (atos falhos) ou dos sintomas propriamente ditos.

Assim, a associação livre permite que se faça o caminho inverso ao recalque, trazendo à luz o material inconsciente através do discurso verbal do paciente. A este, portanto, pede-se que tudo diga e nada faça (Green, 2002), ou seja, que a esfera da ação se mantenha privada e que a comunicação que restrinja ao campo verbal, numa espécie de “...rêverie acordada...” (Green, 2002, p. 55. Tradução nossa.). Através da associação livre e da interpretação das resistências, os objetivos de uma análise consistem em: superar as resistências; tornar consciente o inconsciente - vencendo o recalque e preenchendo as lacunas de memória - e devolver ao paciente a capacidade de amar e trabalhar (Freud, 1904).

Os mais indicados à técnica analítica são os quadros de histeria, fobia e neurose obsessiva, não sendo o método eficaz com as neuroses atuais (Green,

\footnotetext{
${ }^{9}$ Anotações de aula proferida por Luís Claudio Figueiredo, em Agosto de 2012, na SBPRJ.
} 
2002), nem tampouco com as psicoses e neuroses narcísicas (Freud, 1904). Isto porque, nas neuroses atuais, a libido não é suficientemente elaborada, sendo descarregada diretamente no soma devido a um prejuízo simbólico (Green, 2002); e nas psicoses e neuroses narcísicas, a problemática narcísica que faz com que a libido retorne para o eu (Freud, 1914; 1916-17a), impossibilitando o investimento libidinal de objetos externos. É neste contexto que Freud (1912a, 1913) circunscreve certas recomendações para a instauração de um tratamento analítico, anunciadas menos para estipular regras que para minimizar problemas eventuais (Celes, 2006).

No conjunto de textos freudianos referidos especialmente à técnica, na década de 1910, podemos encontrar algumas breves descrições do enquadre em forma de recomendações dirigidas aos analistas. Todavia, Freud sugere que suas diretrizes não se tornem regras rígidas ou imutáveis, visto que

....a extraordinária diversidade das constelações psíquicas envolvidas, a plasticidade de todos os processos mentais e a riqueza dos fatores determinantes opõem-se a qualquer mecanização da técnica... (Freud, $1913: 139$ )

O tratamento analítico é comparado a uma partida de xadrez (Freud, 1913), em que a variedade de jogadas possíveis inviabiliza qualquer organização sistemática de suas regras. Nos textos técnicos, os temas tratados remetem às questões de tempo, dinheiro, papel do analista, entre outros, no contexto do método da associação livre com a contrapartida da atenção flutuante e interpretação das resistências.

Quanto ao lugar do analista, Freud sugere que ele esteja presente como um cirurgião, cuja frieza emocional opera em prol da realização de seu objetivo da forma mais competente possível. Deve usar seu inconsciente como um "instrumento da análise" (Freud, 1912a, p. 129), voltando-o para o inconsciente do paciente como um "órgão receptor" (Freud, 1912a, p. 129), devendo, no entanto, funcionar como um espelho, refletindo de volta os conteúdos trazidos e não mostrando nada além do que lhe é mostrado. A análise pessoal é indispensável, a fim de que os complexos do analista se tornem conscientes, minimizando os pontos cegos e as variáveis prejudiciais ao tratamento de outrem; e a contratransferência, tomada por Freud como “...um obstáculo à análise da transferência...” (Green, 2002, p. 65. Tradução nossa.) deve permanecer 
"controlada" (Freud, 1915 [1914], p. 182), de modo que seus sentimentos não influenciem negativamente o curso da análise.

Em relação ao tempo e ao dinheiro, a hora do paciente é de sua responsabilidade do ponto de vista financeiro, devendo ele pagar pela mesma, compareça ou não. Isto evita que o dinheiro seja usado como forma de resistir à sessão, com faltas ocasionais justificadas por impeditivos acidentais ou pequenas patologias da vida cotidiana (Freud, 1915 [1914]).

Para além da materialidade da moeda, Freud constatou que a questão do dinheiro está intimamente envolvida a fatores sexuais, desde o valor que lhe é conferido até o pudor com que se lida com ele (Freud, 1913). Seu estatuto semântico expande-se, portanto, para o interior da economia pulsional, tornandose um objeto libidinal que perpassa o circuito dos objetos parciais, sendo simbolicamente equivalente a fezes, pênis e bebê (Birman, 1989; Coutinho, 1989). Sendo assim, o dinheiro deve permanecer uma constante que, por sua vez, se torna parte da dinâmica transferencial. Logo, não deve ficar de fora da escuta clínica, já que circula de forma dinâmica no processo analítico através de suas representações psíquicas (Birman, 1989). Deste modo, o dinheiro é uma das précondições para o compromisso profissional, sendo parte do enquadre analítico ou do "não-processo" (Bleger, 1967), resultando ainda num potencial material para a análise, logo interpretável e manejável psiquicamente dentro da ética da psicanálise. Nas palavras de Coutinho (1989):

...o ato do pagamento marca um acordo tácito que se renova a cada vez, um compromisso onde se reafirma o desejo de análise. É no, e pelo pagamento, que se legitima simbolicamente o lugar do analista. (Coutinho, $1989: 220$ )

No entanto,

...outras variáveis entram na composição do eixo transferencial. As transações que envolvem dinheiro certamente evocam reações consequientes com as idiossincrasias de cada um. $\mathrm{O}$ acordo celebrado no contrato é pouco significativo em relação aos fantasmas que emergem no processo. Os conflitos inerentes à situação transferencial vão se refletir na questão do dinheiro. É quando a habilidade do analista é posta à prova. (Coutinho, 1989 : 220)

Deste modo, as questões relativas ao dinheiro também podem expressar resistência ou meios de pôr a situação analítica em xeque, configurando uma 
forma de ataque ao enquadre. Neste sentido, o custo do pagamento é também aquele da entrada em análise, não sendo mais caro, segundo Freud (1913), que o custo alto da doença e da ignorância.

No que se refere ao aspecto temporal, a duração de cada sessão é estipulada previamente, bem como os dias da semana em que elas irão se dar. Diferentemente, a duração do tratamento é a princípio desconhecida, sendo necessário, no entanto, longos períodos para se operar as mudanças mais profundas, já que as idas e vindas, progressões e regressões enquanto movimentos do inconsciente atemporal fazem com que o tratamento dure mais do que o esperado pelo paciente:

Vale dizer, o tempo não é avaliado apenas de forma cronológica, como o tempo social de trabalho que define a troca de um serviço, elemento exterior ao processo analítico, mas como uma temporalidade subjetiva que é regulada pela estrutura psíquica e assujeitada, portanto, às oscilações e cadências dessas estruturas. (Birman, $1989: 231$ )

Assim, os elementos que compõem o enquadre são indissociáveis do processo analítico que é posto em movimento sobre suas bases, havendo uma correlação ou “apoio mútuo” (Roussillon, 2008 [1995b], p. 114) entre o processo e o não-processo a partir do qual aquele se desdobra. Por estabelecer condições que otimizam o método psicanalítico, o enquadre como convenção ou contrato consentido entre as partes é o que torna o processo analisável, e “...neste sentido, não há análise sem enquadre...” (Roussillon, 2008 [1995b], p. 112).

Deste modo, os dispositivos temporais, financeiros e espaciais falam em concretude aquilo que no interior do processo deverá ser elaborado através da palavra (Roussillon, 2008 [1995a]). Neste aspecto, Roussillon (2008 [1995b]) entende o enquadre como algo a ser internalizado pelo analisando ao longo do tratamento: a situação analítica capaz de instaurar a confiança no paciente deverá ser assimilada cada vez mais como fundamental e não como forma de o analista exercer qualquer forma de imposição. Neste sentido, o questionamento do enquadre é comum enquanto forma de apreender seu significado, e sua incolumidade vem ainda atestar seu grau de pertinência:

Se o campo está lá de início, pressuposto na instauração da situação, ele está ao mesmo tempo em questão, ele deverá fornecer a prova efetiva de sua 
pertinência e de sua credibilidade, ele não se manterá - se perderá e se reencontrará - que com a condição de fazer periodicamente a prova de sua credibilidade. Se o enquadre gera, sustenta o processo, este último, por sua vez, deve sustentar apoiar a pertinência do enquadre. Enquadre e processo estão em duplo apoio, em apoio mútuo. (Roussillon, 2008 [1995b] : 114. Tradução nossa.)

Uma vez delimitadas as bases do enquadre, o processo que se constrói dentro de seus limites diz respeito à relação transferencial, paradoxalmente imprescindível ao progresso da análise e aquilo que lhe traz as maiores dificuldades (Freud, 1912b).

Embora fazendo parte do processo, a transferência na clínica contemporânea articula-se intimamente ao não-processo (Bleger, 1967), no que tange aos frequentes ataques ao enquadre efetuados pelos casos-limite. Pois se a destrutividade se presentifica como característica central na clínica com estes casos (Winnicott, 1969 [1968]; Green, 2002), é pela transferência que são veiculadas suas manifestações majoritárias.

Classicamente, a transferência consiste numa reedição de investimentos objetais significativos do passado do paciente, cujos desejos inconscientes para com tais objetos se atualizam, na clínica, na figura do analista (Freud, 1905; Laplanche e Pontalis, 2001[1982]).

São reedições, reproduções das moções e fantasias que, durante o avanço da análise, soem despertar-se e tornar-se conscientes, mas com a característica (própria do gênero) de substituir uma pessoa anterior pela pessoa do médico. Dito de outra maneira: toda uma série de experiências psíquicas prévia é revivida, não como algo passado, mas como um vínculo atual com a pessoa do médico. Algumas dessas transferências em nada se diferenciam de seu modelo, no tocante ao conteúdo, senão por essa substituição. São, portanto, para prosseguir na metáfora, simples reimpressões, reedições inalteradas. (Freud, 1905 : 111)

Todavia, é na medida em que a transferência reproduz certos elementos do passado de forma atual e manifesta que constitui-se, de igual modo, como a resistência mais tenaz ao tratamento. Seu caráter atual na relação com o analista impede que os conteúdos patogênicos sejam trazidos em forma de lembrança, dificultando o objetivo inicial da rememoração (Freud, 1904; 1912b). Assim a resistência, velha conhecida que "...acompanha o tratamento passo a passo" (Freud, 1912b, p. 114-5), ganha a transferência como sua aliada, pois a 
intensidade e a persistência desta constituem “...efeito e expressão” (Freud, 1912b, p.116) daquela.

O manejo da transferência é, portanto, aquilo que traz os maiores impasses ao trabalho analítico, já que o fenômeno se lança à frente das associações, interrompendo-as porque distraindo o paciente com algo relativo ao analista, inserido no núcleo da cena transferencial. Aos poucos desenvolve-se uma neurose de transferência (Freud, 1914; 1916-17a) como uma “...região intermediária entre a doença e a vida real... (...) ...uma doença artificial... acessível à nossa intervenção" (Freud, 1914, p. 170). A tarefa terapêutica consiste em manejar os novos sintomas como correlatos daqueles inicialmente trazidos ao tratamento, eliminando-os via análise da neurose de transferência, só passível de desenvolverse, no entanto, nos casos de histeria, neurose obsessiva e fobia, ficando excluídas as psicoses e neuroses narcísicas, incapazes de investir em objetos (Freud, 191617a).

Os casos inapropriados são também entendidos como aqueles para os quais as "...condições externas desfavoráveis" criaram “...resistências externas..." (Freud, 1916-17b, p.459) que não podem ser superadas, diferentes das resistências internas - parte da estruturação psíquica (Celes, 2006) - normalmente atravessadas pelo tratamento. As resistências externas provêm "...das circunstâncias do paciente, de seu ambiente, [que] são de pouco interesse teórico, mas de maior importância prática." (Freud, 1916-17b, p.459).

Em tal contexto, a relevância prática parece somente se referir à seleção de pacientes conforme sua capacidade de estabelecer ou não uma neurose de transferência, embora alguns anos antes Freud (1905 [1904]) tenha considerado a possibilidade futura de uma modificação na técnica, tornando possível o acesso a estes pacientes:

...As psicoses, os estados confusionais e a depressão profundamente arraigada (tóxica, eu poderia dizer), por conseguinte, são impróprios para a psicanálise, ao menos tal como tem sido praticada até o momento. Não considero nada impossível que, mediante uma modificação apropriada do método, possamos superar essa contra-indicação e assim empreender a psicoterapia das psicoses. (Freud, 1905 [1904] : 250)

Os fatores ambientais serão considerados posteriormente por autores pósfreudianos, sobretudo Winnicott, pela atenção conferida à relação mãe-bebê nos 
primeiros meses de vida do lactente. Isto tanto com o objetivo de compreender melhor os efeitos do ambiente sobre a constituição psíquica quanto para efetuar o tratamento analítico de casos mais graves, ampliando assim o alcance do método analítico clássico.

No tratamento das neuroses, não havendo como fugir à trama transferencial, toda luta terá de ser travada no campo da transferência (Freud, 1912b), com o manejo abstinente por parte do analista, cuja postura é de receptividade sem cumplicidade (Green, 2002), de recusa a qualquer retribuição amorosa (Freud, 1915 [1914]). Neste contexto, a transferência deverá ser associada com elementos da vida pregressa do paciente que se repetem na análise sob os auspícios da “compulsão à repetição" (Freud, 1914a, p. 166), sendo maior a resistência na medida em que a repetição se mostra mais intensa. Deste modo, o paciente não recorda, tal como o idealmente esperado, mas atua, repete, sendo esta a nova maneira de recordar com a qual a técnica analítica se depara. A busca pela lembrança torna-se, portanto, a compreensão daquilo que se apresenta com caráter real e atual, e assim já não se pode “...vencer um inimigo ausente ou fora de alcance." (Freud, 1914, p. 168).

O paciente será levado a elaborar as resistências (Freud, 1914), tomando consciência de seus impulsos pulsionais através da compreensão da transferência e dando-se conta que o que se apresenta na situação atual não diz respeito à pessoa do analista, mas a uma repetição de sentimentos vividos inicialmente junto a objetos significativos de seu passado. A elaboração da transferência motivada pela compulsão à repetição consiste na "...parte do trabalho que efetua as maiores mudanças no paciente...” (Freud, 1914, p. 171. Grifo nosso.), pois só através dela é que este poderá compreender a transferência à luz de sua história pessoal. Assim, (e)laborar consiste no trabalho a ser feito, por excelência, pelo paciente em análise, trazendo-lhe os maiores ganhos ao lhe possibilitar um conhecimento maior de sua subjetividade para além do resgate de uma representação recalcada, dando-lhe acesso a uma vida mais razoável e com menor sofrimento.

Ainda na década de 1910, quando Freud (1914a) inicia a formulação do conceito de compulsão à repetição e reconhece que há lembranças que não podem ser resgatadas, os limites da representação são trazidos à tona e o analista se torna menos convicto em sua pretensão inicial de tornar consciente o inconsciente via rememoração. Deste modo, a "clínica da representação" (Celes \& Garcia, 2011, 
p.117) - fundamentada na associação livre e na escuta flutuante - é dificultada e a interpretação cerceada no contex to mesmo onde deveria bem operar.

Frente aos limites impostos à interpretação - sobretudo pela impossibilidade de o paciente tudo recordar ${ }^{10}$-, Freud lança mão de um novo instrumento metodológico com o objetivo de produzir um novo material capaz de abrir acesso ao inconsciente. A nova ferramenta, conhecida como construção (Freud, 1937), já era utilizada na década de 10, podendo ser encontrada no relato clínico do Homem dos Lobos (Roudinesco e Plon, 1998[1997]; Cardoso \& Monteiro, 2012) e no artigo Uma criança é espancada (Laplanche e Pontalis, 2001 [1982]), porém somente na década de 30 o conceito é discutido em seus pormenores, quando Freud retoma explicitamente a teoria da técnica.

Até então, as formas de expressão do inconsciente eram consideradas em função da busca pela realização do desejo e satisfação da pulsão, fossem através dos sonhos, dos sintomas, da transferência e da compulsão à repetição, de acordo com o princípio do prazer/desprazer. Com as novas constatações clínicas provenientes, sobretudo, do atendimento ao Homem dos Lobos - “...o mais belo fracasso da psicanálise” (Green, 1999, p.36) -, do luto impossível na melancolia, dos pesadelos reiterados nas neuroses traumáticas, das tendências masoquistas e das cinco formas diferentes de resistência, o aparelho psíquico passa a ser considerado por um viés além do princípio do prazer. Assim, a partir de 1920, o aparelho psíquico deixa de ser considerado somente em virtude da busca pela ligação e pela satisfação, operando também através de tendências mais arcaicas que almejam o desligamento, a destrutividade e a tendência ao zero (Freud, 1920; Celes \& Garcia, 2011). O que se vê na clínica são, deste modo, resistências de caráter intransponível que tornam certas análises quase ou definitivamente irrealizáveis.

Nas neuroses traumáticas, a ocorrência de um evento traumático é entendida como uma ameaça à vida que, somada ao fator surpresa, teria rompido o sistema pára-excitação, redundando num excesso pulsional (Freud, 1920). Assim, o "mortífero" (Borges \& Cardoso, 2011, p. 105) teria adentrado o psiquismo sem

\footnotetext{
${ }^{10}$ Pois além da impossibilidade da recordação, há os limites impostos pela transferência nas dobras entre fantasia e realidade; pelo repúdio à feminilidade no encontro com a castração, que põe em cena a passividade e o desamparo estruturais; e pelo próprio inconsciente que nunca se esgota, logo é inapreensível em sua totalidade, tornando as interpretações limitadas porque inesgotáveis. (Celes \& Garcia, 2011).
} 
que uma representação fosse encontrada para lhe conferir algum sentido (Borges \& Cardoso, 2011) e o excesso pulsional não teria encontrado vias por onde escoar sua tensão. Nestes casos, o trauma psíquico torna-se um conteúdo enquistado, clivado, cristalizado como um "corpo estranho interno" (Borges \& Cardoso, 2011, p. 106) impossível de ser representado ou elaborado psiquicamente.

Viu-se que os pesadelos repetitivos destes casos - "não-neuróticos" (Freud, 1920, p. 147) - reconduziam à situação da vivência do trauma, reproduzindo-se com uma intensidade alucinatória quase a nível perceptivo, de forma intrusiva e persecutória. Deste modo, a função do sonho de ser o "guardião do sono" (Freud, 1900, p. 608) e de manifestar o desejo inconsciente foi prejudicada e desviada de seus objetivos, instaurando um "colapso do sonhar" (Gurfinkel, 2008, p. 37) que desmantela a capacidade de desejar.

Desta nova perspectiva, a situação analítica não mais se sustenta de acordo com o modelo do sonho (Khan, 1962), e a clínica da representação cede lugar à clínica da pulsão (Celes \& Garcia, 2011). O encontro com o irrepresentável e o inelaborável impõe dificuldades ainda mais sérias ao método, apontando para “...o limite absoluto da interpretação...” (Celes \& Garcia, 2011, p. 128), incapaz de modificar os destinos pulsionais que escapam à ordem de um conflito interno organizado pelo recalque.

Neste contexto, passam a ser consideradas cinco diferentes formas de resistência enquanto movimentos refratários à cura (Freud, 1926). Até então, as resistências eram da ordem do $e u$, sobretudo frente à sexualidade, na tentativa de manter a integridade narcísica a despeito da insistência do recalque. Após 1920, as resistências do $\mathrm{eu}$ adquirem três modalidades, havendo ainda as resistências do isso e do supereu enquanto novos e poderosos empecilhos à cura.

As resistências do $e u$ são aquelas do recalque; da transferência - que possui o duplo valor de ser material interpretável, mas também encobrir certos elementos e paralisar a análise - e do ganho secundário da doença, que traz vantagens “...às quais não é agradável renunciar.” (Mezan, 2006, p. 328). Os conteúdos repetitivos da ordem da pulsão de morte passam a ser considerados resistências do isso, através da pura compulsão à repetição, além da atração do inconsciente sobre o recalque. Já a resistência do supereu, “...a última a ser descoberta, [que] é também a mais obscura...” (Freud, 1926, p. 156), tem sua origem no sentimento de culpa 
inconsciente (Freud, 1923) ou, mais precisamente, na necessidade de punição (Freud, 1924; 1926).

O sentimento de culpa inconsciente opera como uma forma de castigo através do sofrimento, fazendo com que o paciente permaneça doente apesar dos ganhos obtidos no curso do tratamento. Consiste numa manifestação do supereu que, quando muito encharcado pela pulsão de morte, deixa ainda o indivíduo propenso a traumas e acidentes, realizando certas tendências masoquistas que também se aproveitam do tratamento para trazer perturbações maiores e evitar a revelação paulatina do recalcado (Mezan, 2006).

A oposição à cura pelo apego à doença e impossibilidade de progredir configura-se como a "reação terapêutica negativa" (Freud, 1923, p. 57), numa postura desafiadora ao analista presente nas "neuroses mais graves" (Freud, 1923, p. 58):

...devido à postura negativa contra o médico e ao apego dos pacientes aos ganhos da doença, essa resistência se revela como um obstáculo ainda mais forte do que as já conhecidas dificuldades oferecidas pela inacessibilidade narcísica. (...) ...Na verdade, esse sentimento de culpa se expressa somente na forma de uma resistência tenaz contra o restabelecimento e é muito difícil convencer o paciente de que essa é a real razão de ele continuar doente; ele preferirá a explicação mais imediata de que o tratamento analítico não é o método adequado para ajudá-lo. (Freud, 1923 : 57 58)

Deste modo, o sentimento de culpa inconsciente que se expressa clinicamente como reação terapêutica negativa impõe limites ao método interpretativo e o acesso ao conteúdo inconsciente, sobretudo por influência do supereu, pura cultura da pulsão de morte (Freud, 1923). Não só a reação terapêutica negativa, mas todas as formas de expressão do sofrimento nas quais predomina a pulsão de morte voltada para o próprio indivíduo (Freud, 1924) serão tomadas como as mais árduas ao trabalho analítico, já que tornam certas resistências insuperáveis porque mais tenazes e arraigadas.

Mesmo com a constatação dos limites da interpretação na recuperação do recalcado e já no fim de sua obra, Freud não abdica totalmente da busca pela lembrança. Todavia, a interpretação será substituída pela construção (Freud, 1937) como forma de retomar parte da história do paciente que não pode ser lembrada, mas que pode ser (re)construída, auxiliando, assim, sua tomada de consciência. 
A construção consiste no trabalho feito pelo analista com o objetivo de reconstruir as lembranças através de pistas deixadas em fragmentos de sonhos, em associações alusivas e até mesmo através de alguma atitude ou comportamento capaz de remeter ao conteúdo recalcado (Freud, 1937). Diferentemente da interpretação, que se dirige a "....algum elemento isolado do material, tal como uma associação ou uma parapraxia” (Freud, 1937, p. 279) e tem por objetivo desvendar o sentido do sintoma (Mezan, 2006), a construção apoia-se parcialmente na realidade, comportando ainda elementos fantasísticos (Laplanche e Pontalis, 2001 [1982]) que auxiliam a reconstruir a história infantil do paciente. Assim, a construção reúne os resultados das interpretações numa visão mais global da vida infantil (Mezan, 2006) esquecida porém não destruída, já que indícios de sua vivacidade são vistos na transferência e nas repetições de diversas ordens, como por exemplo as atuações.

Com a construção, a tarefa do analista consiste, portanto, em “...completar aquilo que foi esquecido a partir dos traços que deixou atrás de si..." (Freud, 1937, p. 276), provocando senão recordações, novas associações ou qualquer outro material que confirme sua propriedade e adquira um efeito igualmente terapêutico. Deste modo, é a convicção do paciente que assegura a eficácia da construção, pois esta opera como uma conjectura ou “intervenção 'preliminar" (Cardoso \& Monteiro, 2012, p. 138) que será confirmada ou rechaçada no curso ulterior da análise (Freud, 1937). Nas palavras de Freud:

O caminho que parte da construção do analista deveria terminar na recordação do paciente, mas nem sempre ele conduz tão longe. Com bastante frequência não conseguimos fazer o paciente recordar o que foi reprimido. Em vez disso, se a análise é corretamente efetuada, produzimos nele uma convicção segura da verdade da construção, a qual alcança o mesmo resultado terapêutico que uma lembrança recapturada. (Freud, $1937: 284$ )

Assim, no que se refere à teoria da técnica freudiana e a partir dos impasses clínicos e ajustes teóricos, foi construído um caminho que vai da interpretação à construção, do lado do analista, e da recordação à convicção, do lado do paciente, mantendo ainda viva a meta de tornar consciente o inconsciente.

Em relação à estruturação do enquadre, por outro lado, praticamente nada mudou frente às novas descobertas metapsicológicas. Suas condições de base permaneceram as mesmas - inquestionavelmente necessárias à instauração do 
processo -, porém não houve grandes mudanças naquilo que o articula com o método, a não ser por uma formulação mais explícita da construção. Ora, se o enquadre necessariamente articulado ao método baseado na associação livre e na interpretação se estabeleceu primeiramente em função do conhecimento dos processos psíquicos, com a segunda teoria pulsional as formulações metodológicas parecem não acompanhar os novos achados clínicos. A constatação dos limites da interpretação, no entanto, abriu margem para novas construções na teoria da técnica, além de a organização subjetiva nos casos mais graves sugerir uma problemática de ordem pré-edípica, referente às primeiras etapas da constituição egoica, com reflexos importantes na clínica.

\section{2}

\section{O setting em Winnicott}

A contribuição clínica de Winnicott possui um valor inestimável na história da psicanálise, sendo um dos autores mais considerados (Green, 2002; 2008 [1995]) quando o assunto gira em torno do setting analítico e suas vicissitudes, incluindo aí o papel do analista (Winnicott, 1955-6) e o uso que o paciente dele é capaz de fazer (Winnicott, 1955-6; 1968b; 1969 [1968]).

Para Winnicott, o paciente não somente transfere, mas também usa o analista de forma criativa, sendo algo que não consiste, no entanto, numa capacidade presente em todos os casos clínicos (Winnicott, 1968). Neste aspecto, a contribuição maior de Winnicott no que tange à técnica psicanalítica se refere ao "holding analítico" (Lejarraga, 2008, p.07) para os pacientes que não podem fazer uso do analista, cujo percurso de análise deverá seguir da relação ao uso (Winnicott, 1969 [1968]); Januário \& Tafuri, 2011), isto é, do analista enquanto sendo totalmente parte do mundo subjetivo do paciente, até seu reconhecimento como uma entidade separada, não-eu.

Diferentemente de Freud, Winnicott não mantém o setting em segundo plano (Abram, 2000) em prol da interpretação das resistências junto ao processo transferencial que atualiza elementos das relações interpessoais referentes principalmente ao conflito edípico. Como numa alternância entre figura e fundo, Winnicott intercala, por outro lado e sobretudo no atendimento de casos 
fronteiriços, o método interpretativo com o holding propiciado por um setting que se adapta às necessidades do paciente em termos de ego auxiliar, o holding tomando a frente do trabalho por tempo indeterminado, conforme o necessário.

Winnicott considera elementos da comunicação não-verbal que provêm de momentos anteriores à aquisição da linguagem no desenvolvimento emocional primitivo, o que é transposto para a clínica, e desta maneira a troca verbal não figura como a característica decisiva do processo analítico. Para o autor inglês, trata-se mais de uma continuidade que de uma ruptura entre os diversos modos de comunicação, logo poderão ressurgir, na clínica, determinados aspectos que invocam um cuidado materno que é feito não só de palavras:

\footnotetext{
...Mas enquanto para Freud a psicanálise era essencialmente uma "cura verbal" dependente de duas pessoas capazes de falar uma com a outra, para Winnicott o relacionamento mãe-bebê em que a comunicação era relativamente não-verbal havia se tornado o paradigma para o processo analítico, e isso mudou o papel da interpretação no tratamento. (Phillips, 2006 [1998] : 195)
}

Assim, o setting analítico torna-se um espaço para o crescimento pessoal, e não somente para uma tradução do inconsciente recalcado, o ambiente da relação paciente-analista favorecendo o amadurecimento emocional prejudicado por falhas ambientais severas, que se repetirão na clínica quando da regressão em análise (Winnicott, 1954). Vale dizer que a regressão só poderá ser efetuada se tanto paciente quanto analista puderem suportar os riscos que lhe são inerentes, ao invés de prosseguirem numa pseudoanálise ou num conluio que logo se mostrará interminável ou ineficaz, sem contar a alta probabilidade de uma interrupção repentina. Os riscos inerentes a um "trabalho de setting” ou uma “...intervenção pelo setting como facilitador do processo" (Hisdada, 2002, p.04) podem ser ilustrados pela dependência profunda que o paciente adquire nestes períodos, o que irá demandar, em contrapartida, um alto investimento do analista e grandes esforços no manejo da contratransferência.

Foi com a observação de mães e bebês e o atendimento de casos psicóticos e borderlines que Winnicott tomou ciência dos estágios mais iniciais das relações com o objeto, considerando as falhas ambientais que necessariamente ocorreram e que se revelam na clínica principalmente via regressão em análise (Winnicott, 1954; 1955-6; 1959-64). Este interesse pelos primórdios da vida psíquica considerando a importância do ambiente para a constituição egoica e para o 
relacionamento entre pessoas totais - lhe possibilita um novo olhar teórico sobre a prática analítica no campo transferencial/contratransferencial, indo além do método analítico clássico baseado na interpretação das resistências e do conteúdo recalcado. Deste modo, é em consonância com a teoria do desenvolvimento emocional primitivo que a clínica winnicottiana adquire sofisticação, embora esta seja, na realidade, a fonte de suas construções teóricas cada vez mais elaboradas sobre o amadurecimento infantil e o vasto campo das psicopatologias subjacentes.

Além dos instrumentos clínicos utilizados por Winnicott em dispositivos distintos, tais como o jogo da espátula e o jogo do rabisco no atendimento a bebês e crianças, bem como as consultas terapêuticas, em que ele recebia a criança uma única vez, é no texto Aspectos clínicos e metapsicológicos da regressão no contexto analítico (1954) que a mudança no seu posicionamento na clínica com adultos é inicialmente explicitada e que uma teoria do setting analítico ganha lugar. A partir de então, o holding clínico está necessariamente associado à problematização do setting enquanto lugar privilegiado para a revivência dos aspectos maturacionais, sobretudo aqueles perturbados por falhas ambientais severas.

No artigo em questão, Winnicott (1954) diferencia três tipos de pacientes acessíveis ao trabalho analítico, em relação aos quais o analista, por sua vez, encontrará desafios clínicos distintos. No primeiro caso, temos os pacientes que puderam contar com um ambiente que se adaptou às necessidades de modo satisfatório, permitindo a consolidação de uma estrutura egoica capaz de estabelecer relacionamentos entre pessoas totais. Para estes pacientes, os problemas maiores residirão na esfera dos relacionamentos interpessoais. Estes são os casos que Freud avaliava como adequados para a psicanálise, e o estabelecimento do enquadre freudiano transparecia o fato de se considerar a maternagem inicial como um sucesso óbvio. Aqui, o analista "se comporta" (Winnicott, 1954, p. 383), não havendo trabalho maior que o da compreensão da transferência e interpretação das resistências. No segundo caso, temos os pacientes cuja personalidade está recém-integrada, e que se encontram prestes a unir o amor e o ódio. Assim, a análise repousará sobre as questões subsequentes à conquista do status de unidade, sobretudo àquelas referentes à posição depressiva ou estágio do concernimento. Aqui, a técnica não difere totalmente do método analítico clássico, somando-se, no entanto, a indispensabilidade da sobrevivência 
do analista em função dos conteúdos agressivos invocados. No terceiro e último caso, não se pode contar com uma estruturação egoica integrada, logo a problemática central gira em torno dos momentos mais iniciais do desenvolvimento emocional, anteriores à instauração de uma personalidade unitária, bastante distante de uma diferenciação eu-outro.

No terceiro caso ${ }^{11}$, os pacientes vivenciaram situações de falhas ambientais traumáticas nos primórdios da vida psíquica, tendo sido necessário recorrer a defesas radicais como a instauração de um falso self patológico com o objetivo de proteger o self verdadeiro das intrusões ambientais. Deste modo, o self verdadeiro não tomou parte nas reações, mas em contrapartida não teve meios de sentir-se real, restando num lugar oculto e inacessível, tornando-se empobrecido devido à falta de experiências (Winnicott, 1955-6). Na clínica, são comuns as queixas de sentimentos de vazio, futilidade e irrealidade (Winnicott, 1954; 1955-6; 1959-64), o paciente parecendo estar de fato desapropriado de suas experiências pessoais, enquanto que os vínculos permanecem frouxos e atuados, não tendo "...onde se demorar internamente, nem como, costurando-se uns aos outros, entretecerem enredos" (Dias, 2011b, p.71).

No tratamento destes casos, o paradigma clínico está aquém da neurose de transferência e da associação livre dos conteúdos verbais, logo o método psicanalítico clássico encontra seus limites pelo fato de elementos anteriores ao relacionamento entre pessoas totais tomarem a cena. Deste modo, onde predominam as tentativas de comunicação de conteúdos não-verbais, referentes a experiências marcadas na corporeidade e anteriores à aquisição da linguagem (Januário \& Tafuri, 2001) ou da possibilidade de transcrição representacional (Roussillon, 1999b), uma revisão da técnica se faz necessária:

...Em um certo setting, Freud lidou com o material produzido pelo paciente e grande parte de seu trabalho esteve relacionado ao imenso problema de como lidar com esse material.

Em alguns casos, contudo, revela-se ao final, ou mesmo de começo, que o setting e a manutenção dele são tão importantes quanto a maneira pela qual se lida com o material. Em alguns pacientes, com um certo tipo de diagnóstico, a provisão e a manutenção do setting são mais importantes que o trabalho interpretativo. (Winnicott, 1964b : 77)

\footnotetext{
${ }^{11}$ Embora a segunda classe de pacientes efetue explicitamente ataques ao enquadre - o que não exclui, na realidade, nenhuma das três categorias -, nosso foco de atenção estará na terceira categoria especificada por Winnicott, visto nosso objetivo repousar sobre os ataques enquanto tentativas de reconhecimento da alteridade e concomitante instauração dos limites egoicos.
} 
Vale dizer que a classificação diferenciada de pacientes oferecida por Winnicott (1954) não garante sua plena identificação já nas primeiras entrevistas, pois as exigências do paciente são demonstradas conforme ele adquire confiança no ambiente analítico e tão logo começa a ter esperanças de que elas serão atendidas (Winnicott, 1964b). Deste modo, a "loucura privada" (Green, 1990) se revela de forma gradativa e insidiosa, conforme o ambiente demonstra ser possível à regressão à dependência adquirir movimento.

Diferentemente da regressão pensada freudianamente em termos de pontos de fixação libidinal em zonas erógenas, a regressão à dependência articula-se aos prejuízos na organização egoica e a uma ameaça de caos (Winnicott, 1954), como é o caso, por exemplo, do medo do colapso que “....revela o fato de que o verdadeiro self está ausente da cena" (Abram, 2000, p. 30). O medo do colapso emerge na clínica como um sintoma que traz notícias de uma agonia primitiva retorno a um estado não integrado, medo de cair para sempre, fragmentação psicosoma, perda do senso de realidade - vivida num momento em que o ego não possuía maturidade suficiente para integrar e processar a experiência, mas que ainda assim deixou marcas no inconsciente (Winnicott, 1963c). Assim, é somente num ambiente de confiabilidade (Winnicott, 1954; 1964b; 1967) que tais elementos poderão ser (re)experimentados, em parte dentro da área de onipotência do paciente, porém junto a um ego auxiliar, desta vez do analista. Nas palavras do autor:

...Há muitas coisas a estudar aqui sobre o modo como o indivíduo armazena memórias e ideias e potencialidades. É como se houvesse uma expectativa de que surjam condições novas, justificando a regressão e oferecendo uma nova chance para que o desenvolvimento ocorra, esse mesmo desenvolvimento que havia sido inviabilizado ou dificultado inicialmente pela falha do ambiente. (Winnicott, 1954 : 378)

Neste contexto, o paciente efetua uma regressão ao estado de dependência absoluta onde a falha foi inicialmente vivida, com a “...crença numa possibilidade de correção da falha original..." (Winnicott, 1954, p. 377), dentro de um ambiente especializado e propício. Assim, a regressão está relacionada a certas falhas do ambiente que permaneceram congeladas (Winnicott, 1954) estrategicamente como forma de proteger o ego destas falhas específicas e traumáticas. Neste sentido, a 
regressão comporta a esperança de que o trauma seja revivido num ambiente favorável ao amadurecimento emocional, sendo “...parte da capacidade do indivíduo de se curar." (Winnicott, 1959-64, p. 117).

Neste aspecto, embora Winnicott (1954) seja muitas vezes criticado por parecer sugerir uma técnica corretiva, mais adiante ele afirma que “...não é certo que possamos corrigir o que foi deficiente" (Winnicott, 1964b, p. 78). De todo modo e no que nos cabe, preferiremos manter a esperança do paciente como o combustível maior de seu processo de crescimento em análise, relegando a ele próprio o crédito por seus ganhos e conquistas no tratamento. $\mathrm{O}$ analista $\mathrm{o}$ acompanha.

Na visão de Winnicott (1954), a regressão está intimamente associada a um falso self patológico que se desenvolveu em razão das falhas ambientais severas. No tratamento, uma vez adquirida a confiança num ambiente que provê uma "nova oportunidade de dependência" (Winnicott, 1967, p.154) via continuidade, estabilidade e previsibilidade (Hisada, 2002), o falso self "entregase ao analista" (Winnicott, 1955-6, p.396) e uma nova experiência será vivida com o descongelamento da situação da falha original. Neste sentido, embora a regressão atualize a situação traumática de forma extremamente dolorosa (Winnicott, 1954; 1955-6), é em função dos aspectos sadios capazes de reorganizar a estrutura egoica - comprometida em seu processo de amadurecimento - que o centro das experiências é transferido do falso para o verdadeiro self (Winnicott, 1955-6), o único capaz de ser realmente analisado (Winnicott, 1959-64).

Numa situação regressiva, que pode durar alguns minutos ou o tempo de uma sessão ou semanas a fio, o paciente se torna demasiadamente sensível ao setting em todos os seus detalhes (Winnicott, 1964b). Se um dia, por exemplo, a pontualidade do analista deixa a desejar, isto pode se tornar um grande inconveniente e parecer que nenhum trabalho poderá ser efetuado naquele dia. Neste ponto, contudo, reside a grande percepção de Winnicott - que depois será pensada por Bleger (1967) em termos de necessidade de quebra do enquadre - de que o paciente regredido irá usar as falhas do analista como forma de se zangar, pela primeira vez, pelas falhas originais que não puderam ser integradas à experiência e que provocaram as agonias impensáveis e o encobrimento do verdadeiro self (Winnicott, 1954; 1955-6): 
Aprendemos a esperar uma sensibilidade crescente por parte do paciente e começamos a imaginar se é a bondade ou a crueldade que nos motiva. Descobrimos que nossos inevitáveis fracassos específicos e limitados, amiúde ocasionados pelo paciente, dão a este oportunidade para sentir e expressar raiva por nós. Ao invés de um trauma cumulativo, obtemos experiências cumulativas de raiva, na qual o objeto (o terapeuta e a sua sala) sobrevivem à raiva do paciente. Nenhum tratamento de casos borderline pode achar-se livre de sofrimento, tanto do paciente quanto do terapeuta. (Winnicott, $1967: 155-6$ )

Assim, as falhas do analista - que necessariamente ocorrem em qualquer tratamento - terão valor primordial neste tipo de atendimento, pois é somente através delas que a falha original poderá ser relembrada e experimentada de uma nova maneira, isto é, com o sentimento subsequente de raiva que possibilita pela primeira vez a apropriação subjetiva da experiência. Apropriação aqui significa integrar a experiência ao ego, processando-a enquanto uma vivência do self verdadeiro para além da postura submissa que é aquela com a qual somente se pôde contar até então. Mais ainda, remete à raiva vivida em função de uma falha que pode agora, e com a ajuda do analista, ser tomada como vinda do ambiente, isto é, de fora da área de onipotência do indivíduo. Assim,

...a "regressão à dependência" permite que o paciente perceba que uma determinada falha ambiental ocorreu a partir do meio ambiente e não a partir de si mesmo. A experiência de onipotência do paciente tende a incorporar em si a falha do ambiente. Daí a importância da utilização do erro do analista, a partir do qual o paciente pode reconhecer não só a falha do analista como a falha do ambiente, sem se responsabilizar por elas. (Januário \& Tafuri, 2011 : 267)

A mudança na perspectiva do agente causador da falha (agente interno $=$ ego onipotente; agente externo = ambiente) auxilia na diferenciação entre o que provém de dentro e o que vem de fora, tornando as fronteiras interno/externo mais bem delineadas. Além disso, é dada a chance de se atenuar o sentimento de culpabilidade primária que Roussillon (1999b) observa com frequência nos sofrimentos narcísico-identitários, que diz respeito a tomar as falhas graves do ambiente como uma produção própria. Neste caso, perante as falhas severas, o indivíduo é confrontado com um sentimento de mal-estar ao qual ele se identifica, numa época que precedia a diferenciação eu-outro, instaurando uma "confusão primária eu- não-eu” (Roussillon, 1999b, p. 83): 
No lugar da forma matricial da ilusão narcísica primária: "Eu sou o seio" (S. Freud, 1938), se instaura uma ilusão negativa na origem do núcleo da culpabilidade primária: "Eu sou (o) mal." (Roussillon, 1999b : 83. Tradução nossa.)

Deste modo, na visão winnicottiana, o paciente poderá experienciar a falha do analista como fora de sua área onipotente, logo além da identificação primária, sendo necessário, no entanto, que o analista reconheça seu erro enquanto tal (Winnicott, 1955-6). Neste ponto, por mais que as falhas do analista sejam “...pequenas, induzidas pelo paciente ou produzidas por elementos transferenciais delirantes" (Januário \& Tafuri, 2011, p.268), é indispensável que ele assuma sua responsabilidade por elas, sem se defender com uma interpretação de uma suposta resistência ou transferência negativa do paciente (Winnicott, 1955-6).

A falha do analista deverá ser então reconhecida, porém deduzida como uma falha antiga que pode ser agora experienciada com raiva, “...vigor e vitalidade genuínos." (Winnicott, 1954, p.384). Se o analista, por outro lado, interpreta neste momento de regressão profunda, a interpretação terá efeitos de intrusão ao mostrar o analista como um elemento não-eu quando na verdade ele ainda é parte subjetiva do paciente:

Mais perigoso, contudo, é o estado de coisas na análise em que o analista é deixado, pelo paciente, atingir as camadas mais profundas da personalidade do analisando por causa de sua posição como objeto subjetivo... (...); aí há perigo do analista interpretar, ao invés de esperar que o paciente descubra criativamente. É somente aqui, no lugar em que o analista ainda não mudou de objeto subjetivo para um que é objetivamente percebido, que a psicanálise é perigosa, e o perigo é tal que pode ser evitado se sabemos como nos comportar. Se esperamos nos tornamos percebidos objetivamente no devido tempo pelo paciente, mas se falhamos em nos comportar de modo que facilite o processo analítico do paciente (que é o equivalente ao processo maturativo do lactente e da criança) subitamente nos tornamos não-eu para o paciente, e então sabemos demasiado, e ficamos perigosos porque estamos demasiado próximos na comunicação com o núcleo central quieto e silencioso da organização do ego do paciente. (Winnicott, 1963e : 171-2)

Isto não quer dizer que na neurose de transferência o analista seja considerado apenas como um outro diferenciado, sendo também, pelo contrário, alvo de projeções a todo momento. Porém, no borderline esta situação é mais dramática, já que o uso do analista ainda não foi conquistado (Lejarraga, 2012), portanto a interpretação stricto sensu deverá ser evitada até o momento em que o paciente não estiver mais amalgamado ao analista. Para os casos em questão, o 
analista não representa a mãe, ele “...é a mãe.” (Winnicott, 1954, p. 385. Grifo do autor.). Sendo assim, “...enquanto na neurose de transferência o passado vem ao consultório, neste tipo de trabalho é mais correto dizermos que o presente retorna ao passado, e é o passado.” (Winnicott, 1955-6, p. 396. Grifo do autor).

Por esta razão, o setting analítico se configura enquanto uma reprodução dos cuidados maternos iniciais, e o analista se vê às voltas com questões de necessidade mais do que de desejo (Winnicott, 1954).

Embora Winnicott nunca tenha definido claramente o que ele chama de necessidades egoicas, preferindo deixar em aberto esta questão (Roussillon, 2000 [1999]), podemos entendê-las como aquilo que o ego necessita para se apropriar subjetivamente das experiências vividas que compõem a sua história, mas que não puderam contar com um trabalho psíquico de representação ou inscrição simbólica. Sendo assim, uma “...adaptação suficientemente boa do analista..." (Winnicott, 1955-6, p. 396) não significa satisfazer, simplesmente, mas oferecer um ambiente capaz de sustentar o processo analítico com todas as dificuldades que se apresentam, incluindo aí a capacidade de esperar e respeitar as defesas do paciente. Trata-se, sobretudo, de dar suporte ao conjunto de experiências (re)vividas na relação com o analista, ajudando a integrá-las subjetivamente em termos de tempo e espaço. Nos comentários de Januário \& Tafuri (2011):

A noção de holding na teoria winnicottiana é de extrema importância para o manejo clínico e é compreendida como sustentação - sustentam-se determinadas experiências ao longo de um tempo sem interromper a experiência do paciente. Significa oferecer um ambiente/setting que sustente e permita o processo de integração do sujeito. (...). Em casos extremos, talvez seja necessário que, em algum momento da análise, o holding assuma uma forma física, mas Winnicott relaciona esse cuidado com a compreensão do sofrimento do paciente e da expressão dessa compreensão, de modo que o paciente se sinta sustentado pelo analista: "toda vez que compreendemos profundamente um paciente, e o mostramos através de uma interpretação correta e feita no momento certo, estamos de fato sustentando o paciente". (Januário \& Tafuri, 2011 : 262-3; Winnicott, 1954 : 354 apud Januário \& Tafuri, 2011 : 263)

A partir da citação acima, vemos que não se deve entender Winnicott como um analista avesso à interpretação. $\mathrm{O}$ que o autor sugere é que a técnica interpretativa seja tomada com ressalvas, principalmente nos momentos de profunda regressão. Sua experiência demonstrou-lhe que muitas vezes o fato de ser arguto e apressado numa interpretação pode fazer com que esta venha cedo 
demais, operando uma intrusão e impedindo que o paciente chegue à compreensão ele próprio, criativamente (Winnicott, 1969 [1968]). Enquanto o paciente não tiver meios de "...colocar o analista fora da área dos fenômenos subjetivos" (Winnicott, 1969 [1968], p. 122), a análise deverá seguir seu curso no sentido de o paciente adquirir a capacidade de usar o analista, e só então fará sentido trabalhar através da interpretação das resistências. Apesar disso, uma interpretação pode tomar o formato de holding e significar cuidado materno (Phillips, 2006 [1988]) uma vez que se dirigir à dimensão da existência, do viver e do sentir-se real, revelando em palavras e no momento adequado que o analista compreende a intensa ansiedade que o paciente experimenta (Winnicott, 1963d).

Nestes sentido, no intuito de evitar a formalização de modelos através de um antagonismo reducionista, Oliveira (2012) propõe o termo "interpretaçãoholding", salvaguardando a singularidade dos conceitos, mas mantendo, ainda, “...o caráter relacional destas duas dimensões de acolhimento ao paciente." (Oliveira, 2012, p.107). Pois, como vimos com o próprio Winnicott (1955-56), um tipo de técnica não exclui o outro, e o ir e vir entre ambos ocorre sempre em função dos processos inconscientes do paciente.

Desta maneira, assim como a "modificação de técnica necessária quando está se tratando um caso borderline" (Winnicott, 1963c, p. 215) é uma questão de ênfase, podendo o holding abrir espaço ao trabalho interpretativo, quando possível, o holding está igualmente presente nas diversas modalidades de escuta e intervenção, não se restringindo ao atendimento de casos psicóticos e borderlines. Como ilustra Winnicott (1990) em uma de suas passagens:

\footnotetext{
...Uma interpretação correta e oportuna no tratamento analítico produz uma sensação de estar sendo fisicamente seguro, que é mais real (para o não-psicótico) do que se ele estivesse sendo concretamente embalado ou posto no colo. A compreensão penetra mais fundo, e através da compreensão demonstrada pelo uso da linguagem, o analista embala o paciente fisicamente no passado, ou seja, na época em que havia necessidade física de estar no colo, quando o amor significava adaptação e cuidados físicos. (Winnicott, 1990 : 80)
}

Ou, nos comentários de Phillips (2006 [1988]), tal como bebê é capaz de sinalizar suas necessidades, o paciente fornece as pistas para o trabalho do analista: 
...O analista, assim como a mãe, é um facilitador por oferecer a oportunidade para a comunicação e o reconhecimento desta. Assim como o alimento pode ser visto como uma interpretação do choro do bebê pela mãe, da mesma forma as interpretações verbais do analista podem ser vistas como alimento em forma de linguagem para o paciente. (Phillips, 2006 [1988] : 198)

Nesta perspectiva, a interpretação adquire um caráter polissêmico no setting winnicottiano, a nosso ver um espaço analítico polifônico. A alternância na ênfase entre holding e interpretação - lembrando que muitas vezes a própria interpretação é uma forma de holding - possibilita aos pacientes mais graves o sentimento de enfim começar a viver e sentir-se reais, abrindo margem à resignificação das experiências que redundaram no sofrimento psíquico. $\mathrm{Na}$ clínica winnicottiana, portanto, os “...sentimentos agonizantes podem ser transformados em experiências positivas" (Januário \& Tafuri, 2011, p. 262-3) quando a reprodução do fracasso original permite que o falso self se entregue ao analista, possibilitando um crescimento verdadeiro no lugar de uma vida baseada nos padrões de reação e submissão:

Num tratamento bem-sucedido, o paciente se torna capaz de pôr em cena o trauma ou o fracasso ambiental... [e assim] ...somos transformados em pais que fracassam e somente desse modo alcançamos sucesso como terapeutas. (Winnicott, 1961, p. 60-61).

Deste modo, é somente por uma atenção dirigida aos elementos regressivos que se expressam no e através do setting que o percurso do amadurecimento egoico poderá ser retomado, chegando até a capacidade de uso do analista (Winnicott, 1969 [1968]; Januário \& Tafuri, 2011), o que implica na sua destruição no âmbito subjetivo para seu reconhecimento subsequente no âmbito da alteridade. Neste sentido, a não-retaliação e sobrevivência do analista ou a "incolumidade da técnica" (Winnicott, 1969 [1968], p.128) perante os ataques permitirão o reconhecimento do "outro não-eu" (Januário \& Tafuri, 2011, p.264), contribuindo igualmente para uma melhor demarcação das fronteiras egoicas, tão ruidosas quanto incertas no paciente borderline. 


\section{3}

\section{A situação analítica como campo dinâmico e a psicanálise do enquadramento psicanalítico}

Em um trabalho considerado um dos mais relevantes e criativos a respeito do enquadre (Figueiredo, 2011), Willy e Madeleine Baranger (1961-62) ${ }^{12}$ tomam a situação analítica como um campo dinâmico que envolve duas pessoas, o analista sendo parte integrante de um processo inteligível somente ao se considerar ambas as partes envolvidas. Ao invés de o processo ser observado de forma objetiva e unilateral, levam-se em conta os significados latentes da comunicação verbal, os meios inconscientes de comunicação e os aspectos contratransferenciais utilizados como instrumento técnico indispensável à compreensão do que se passa dentro do campo. Neste sentido, o próprio campo é o objeto da observação, incluindo aí não somente a observação do analisando, mas também a auto-observação do analista.

O campo contém determinados aspectos espaciais e temporais, além de comportar uma "configuração funcional básica" (Baranger, 1961-62, p. 131) constituída pela associação livre e pela interpretação, os quais espera-se que estejam presentes durante todo o tratamento. No âmbito espacial, qualquer mudança efetuada na estrutura física da sala interfere na relação analítica, implicando em "mudanças vivenciais" (Baranger, 1961-62, p. 130) transferenciais-contratransferenciais. Neste caso, a opção divã-poltrona ou a posição frente a frente já revela, por si só, uma "atitude interna particular" (Baranger, 1961-62, p. 130) do analista para com o paciente. Os aspectos temporais, por sua vez, são bem delimitados em termos de horários, duração da sessão e férias, mas também podem sofrer distorções e romper a uniformidade prévia, dependendo da forma com que ambos os envolvidos lidam com os objetos e com a angústia, o âmbito temporal refletindo o campo analítico global. Neste contexto inicial, o contrato de base (tempo, dinheiro, regra fundamental, entre outros) deve ser mantido, sobretudo, pelo analista, que pode lançar mão da interpretação para restituir a estruturação original, caso o paciente falte com o acordo.

\footnotetext{
${ }^{12}$ As traduções deste artigo são todas nossas.
} 
A configuração funcional básica é também entendida como "relação terapêutica bipessoal" (Baranger, 1961-62, p. 132), em que estão presentes descritiva e perceptivelmente duas pessoas "em carne e osso" (Baranger, 1961-62, p. 132), porém divididas vivencialmente em terceiros ou ainda em muitas partes fragmentadas. Assim, o analista pode encarnar tanto o supereu do analisando quanto os impulsos recalcados do $i d$, a situação bipessoal servindo de solo para "situações tri e multipessoais" (Baranger, 1961-62, p. 132) que operam através de clivagens múltiplas colocadas em cena - também pelo analista, vale dizer, porém em menor escala. Deste modo, a situação bipessoal se mantém como pano de fundo, "presente ainda que não percebido" (Baranger, 1961-62, p. 132), só desaparecendo completamente em situações de intensa regressão, se porventura o analista se desvincula de sua posição originalmente abstinente e a situação analítica se desintegra ao perder-se o compromisso de base.

Neste sentido, a situação bipessoal abrange inúmeras outras, "...superpostas ou misturadas, distintas mas nunca claramente delimitadas" (Baranger, 1961-62, p.133), em que os acontecimentos comportam uma "ambiguidade essencial" (Baranger, 1961-62, p.133) que nos leva a pensar o campo como uma situação de "como se" (Baranger, 1961-62, p.133). Assim, a situação analítica é sempre e ao mesmo tempo uma outra coisa, a ambiguidade perpassando todos os elementos que compõem o campo dinâmico. No âmbito temporal, por exemplo, a análise reúne presente, passado e futuro numa dupla onde se vivenciam diversas outras duplas (pais e filhos, casais, irmãos, amigos e inimigos), mas “...onde não se atua nenhuma delas” (Baranger, 1961-62, p.142). Assim, a vivência atual junto ao analista consiste na revivência de uma relação passada com os objetos arcaicos, permitindo elaborar psiquicamente o peso bruto dos traumas infantis através de resignificações e reinserções do analisando em sua história pessoal.

A ambiguidade pode ser vivenciada também a nível corporal dentro do campo, sobretudo quando o paciente faz sentir no analista determinados elementos clivados via identificação projetiva. Neste sentido, o analista é "depositário" (Baranger, 1961-62, p.156) de partes cindidas do self, sendo passível de responder a esta comunicação com uma "contraidentificação projetiva corporal" (Grinberg, 1965 apud Baranger, 1961-62, p. 136). Esta, no entanto, deve ser compreendida em termos contratransferenciais e necessariamente 
interpretada (Baranger, 1961-62; Baranger \& Mom, 2002 [1982]). O interjogo de identificações projetivas, introjetivas e as contraidentificações, aliás, compõem a fantasia inconsciente que sempre existe e subjaz a toda a estrutura do campo bipessoal:

O campo bipessoal da situação analítica está orientado, em cada momento, segundo três (ou mais) configurações: o contrato de base, a configuração aparente do material manifesto com a função que nela tem o analista, e a fantasia inconsciente bipessoal objeto da interpretação. Esta é uma estrutura constituída pelo interjogo dos processos de identificação projetiva e introjetiva e das contraidentificações que atuam com seus limites, funções e características distintas dentro do analisando e do analista. (Baranger, 1961-62 : 145)

Assim, há um conteúdo latente subjacente não só à comunicação verbal, mas também ao próprio campo dinâmico, estruturado sobre “...fantasias inconscientes compartilhadas..." (Figueiredo, 2011, p.140) entre paciente e analista. Deste modo, a fantasia inconsciente do analista também está incluída no campo, porém não se impõe nem é somada à do analisando, já que a fantasia compartilhada é “...algo que se cria entre ambos, dentro da unidade que constituem e no momento da sessão, algo radicalmente distinto do que são separadamente cada um deles." (Baranger, 1961-62, p. 141. Grifo do autor.).

A "fantasia básica de uma sessão" (Baranger, 1961-62, p. 140) - isto é, o que se constrói por ambos num determinado espaço de tempo - constitui o "ponto de urgência" (Baranger, 1961-62, p. 140) a ser interpretado naquele momento, já que nela convergem o conteúdo manifesto, o conteúdo latente e a fantasia atual que permeia o contrato, para além daquele explicitamente delimitado como as condições de base. Assim, o contrato explícito é somente a superfície de um outro contrato, inconsciente, que pode ser compreendido à luz da história de vida do paciente, e que se torna manifesto no momento em que este efetua uma alteração no contrato ou uma quebra no enquadre.

Enquanto o paciente está submerso no campo, o analista, embora dele faça parte - e é isto o que torna a interpretação terapêutica -, pode observá-lo com certa "porosidade" (Baranger, 1961-62, p. 154), mas sem se deixar invadir. O analista, portanto, “...comprometido em carne, inconsciente e osso...” (Baranger \& Mom, 2002 [1982], p. 119), deve estar atento à dinâmica do campo no que concerne principalmente à sua mobilidade ou paralisação. Neste ponto, a forma mais frequente de paralisação se dá através de um “...obstáculo mais além das 
resistências acostumadas do analisando" (Baranger \& Mom, 2002 [1982], p. 115), algo que entorpece ou detém o processo e que se convencionou chamar de "baluarte" (Baranger, 1961-62; Baranger \& Mom, 2002 [1982]).

O baluarte existe sempre e consiste num “...refúgio inconsciente de poderosas fantasias de onipotência" (Baranger, 1961-62, p.151) que todo paciente evita pôr em jogo numa análise, já que o risco de sua perda levaria a um estado de extrema vulnerabilidade. Assim, “...a imobilização do campo é sempre uma medida de proteção destinada a preservar a intrusão do analista e de suas interpretações dentro de um setor reservado da vida do analisando.” (Baranger, 1961-62, p. 151)

Desta maneira, o baluarte impossibilita que o processo se desenvolva a partir de certo ponto, sendo ainda capaz de interrompê-lo por completo. Por outro lado, como é de se esperar, uma análise se alterna em momentos de processo e não-processo, sendo este compreendido por Baranger \& Mom (2002 [1982]) como tudo aquilo que se contrapõe ao processo e ao caminhar do tratamento (Leivi, 2002; Rocabert, 2002). Assim, tal como Freud (1904) localizou o conhecimento do recalcado na superação das resistências, aqui o trabalho consiste também na superação dos obstáculos, considerando, porém, uma inserção maior do analista, já que ele também está implicado na instauração e manutenção do baluarte (Baranger \& Mom, 2002 [1982]).

O baluarte, portanto, envolve ambos os participantes num pacto capaz de levar à patologização do campo (Baranger \& Mom, 2002 [1982]).

Fala-se normalmente do par resistência-contraresistência. Este par é o que leva ao baluarte: uma colusão entre resistências do paciente e resistências do analista, que entendemos como uma formação cristalizada dentro do campo que estanca a dinâmica deste. Analista e analisando dão voltas ao redor de um obstáculo sem poder integrá-lo ao processo. (Baranger \& Mom, 2002 [1982] : 129)

Assim, os "pactuantes" (Baranger \& Mom, 2002 [1982], p. 115. Grifo dos autores.) estão reunidos não só por fantasias inconscientes compartilhadas, mas também por "resistências compartilhadas" (Figueiredo, 2011, p. 140) que cumprem o papel de “...pontos cegos e sob o domínio da compulsão à repetição da dupla." (Figueiredo, 2011, p. 140). 
Ela [a estrutura baluarte] se caracteriza por não aparecer nunca diretamente na consciência de ambos participantes, manifestando-se tão somente por efeitos indiretos: provém de uma cumplicidade entre ambos protagonistas na inconsciência e no silêncio para proteger um engate que não deve ser desvelado. Isso desemboca numa cristalização parcial do campo, numa neoformação constituída ao redor de uma montagem fantasmática dividida que implica zonas importantes da história pessoal de ambos participantes, e que atribui a cada um, um rol imaginário estereotipado. (Baranger \& Mom, 2002 [1982] : 115-16)

Se o baluarte permanece como um "corpo estranho estático" (Baranger \& Mom, 2002 [1982], p. 116) mas não é analisado, o tratamento só aparentemente segue o seu curso. Vigora uma estrutura circular numa "repetição estéril" (Rocabert, 2002, p. 137) repleta de estereotipias e pseudo-insights destinados a enganar quanto à existência do progresso. O pseudo-insight não abre uma dimensão de futuro e as trocas transferenciais-contratransferenciais são desprovidas de movimentos e transformações. Neste contexto, a estereotipia disfarçada de processo tende a eternizar o tratamento, e a observância às regras não se mostra mais do que complementar à manutenção do baluarte.

O não-processo, em certos casos, pode expressar-se sob a forma de um movimento aparentemente bem encaminhado: são estes tratamentos que "caminham sobre trilhos", onde o analisando vem pontualmente, associa, escuta, aprova a interpretação, inclusive gratifica o analista com resultados terapêuticos bem visíveis, dando-lhe a impressão de um trabalho útil. No analista o sinal de alarme pode ser que "este tratamento anda demasiado bem", juntamente com o sentimento de que "aqui não acontece nada". (Baranger \& Mom, 2002 [1982] : 128. Grifo dos autores.)

Esta que é a questão estudada por Bleger (1967) - o cumprimento do enquadre encobrindo elementos inconscientes essenciais - pode se tornar mais grave quando o baluarte invade completamente o campo, transformando-o num campo patológico caracterizado por uma "simbiose insuperável" ou, mais ainda, por um "parasitismo aniquilante do analista pelo analisando" (Baranger \& Mom, 2002 [1982], p. 117). Neste caso, o analista sente-se habitado pelo paciente numa situação permeada por identificações projetivas que instauram certas "micropsicoses no campo analítico” (Baranger \& Mom, 2002 [1982], p. 125) e que demandam do analista uma "segunda olhada" (Baranger \& Mom, 2002 [1982], p.115).

A segunda olhada consiste numa "posição meta" (Rocabert, 2002, p. 137) ou numa visão de um outro ângulo capaz de resgatar o analista da submersão na 
resistência compartilhada, incluindo a contratransferência como um importante indicador acerca do que ocorre ali dentro. Uma vez reconhecidas as identificações projetivas, a interpretação é utilizada com o objetivo de reintrojetar no paciente os conteúdos próprios a ele, favorecendo o "insight verdadeiro" (Baranger \& Mom, 2002 [1982], p. 127) ao passo que o analista é esvaziado das projeções e realocado novamente em sua distância necessária.

O resultado do processo do "insight" sobre a situação analítica é característico: a maior discriminação faz aparecer momentaneamente o campo bipessoal como o que é, um campo experimental, e o analista perde suas características fantasiadas para ser vivenciado segundo sua função essencial: é o analista e não o pai, a mãe, a onipotência, etc.... do analisando. Por este processo, no curso da análise, o analista vai perdendo paulatinamente seus aspectos fantásticos ao mesmo tempo que a relação transferencial se faz mais serena e mais autenticamente cordial e comunicada. (Baranger, 1961-62: 162)

Assim, uma interpretação adequada proporciona uma reestruturação do campo através do insight capaz de tornar consciente o inconsciente, tal como formulado por Freud (1904). No entanto, para que o tratamento alcance mais conspicuamente aquilo que se propõe a fazer, é necessário efetuar a queda e a análise dos baluartes (Baranger, 1961-62; Baranger \& Mom, 2002 [1982]).

A queda do baluarte incide numa mudança de vivência nas duas partes envolvidas; na restituição do movimento ao campo e numa "de-simbiotização" (Baranger \& Mom, 2002 [1982], p.125), já que o baluarte está calcado num conjunto de transferências e identificações projetivas de ambos. A queda do baluarte é sempre vivida pelo paciente como “...catastrófica, e logo como enriquecimento positivo" (Baranger, 1961-62, p. 152), pois ele é levado a abdicar de suas fantasias básicas de onipotência, porém com os ganhos subsequentes de reintegrar parte de sua história pessoal que se manteve clivada, resignificando assim os traumas infantis num ambiente propício à sua revelação e tratamento. $\mathrm{O}$ analista, por sua vez, passa espontaneamente “...da segunda olhada à primeira olhada..." (Baranger \& Mom, 2002 [1982], p.125), o que sugere um trabalho operando somente com as resistências do paciente. Neste sentido, o tratamento progride na medida em que os baluartes vão sendo identificados e desfeitos dinamicamente no campo analítico: 
...O campo da situação analítica é a oportunidade, mediante a repetição em um contexto novo das situações originais que motivaram a clivagem, de romper este processo defensivo e reintegrar os setores clivados da experiência ao conjunto da vida do analisando. Daí a necessidade de desmoronar os baluartes internos. (Baranger, 1961-62:153)

Para Bleger (1967), outro importante autor engajado na discussão sobre o setting, é somente com a quebra do enquadre que os elementos arcaicos, de ordem simbiótica, podem ser trazidos à tona e integrados ao processo. Seu ponto de partida, no entanto, é buscar compreender os problemas trazidos ao enquadre não quando ele se rompe ou é atacado, mas quando se mantém imóvel numa análise que poderia ser chamada de "ideal” (Bleger, 1967, p. 312), em função do total cumprimento das regras estabelecidas. Isto porque, por mais que as delimitações do enquadre devam ser mantidas, um tratamento analítico não é de fato aprofundado se não for feita uma análise do próprio enquadre, em todo e qualquer caso.

Segundo Bleger (1967), a situação analítica comporta “...a totalidade dos fenômenos envolvidos na relação terapêutica entre analista e paciente..." (Bleger, 1967, p. 311. Grifos do autor), incluindo os elementos do processo e do nãoprocesso. O processo corresponde ao objeto analítico por excelência, constituído pelas transferências e resistências do paciente que se desenvolvem no tratamento analítico, foco primordial da interpretação. Já o não-processo, diferentemente da concepção de Baranger \& Mom (2002 [1982]), diz respeito às constantes dentro das quais o processo se desenvolve, isto é, a estrutura formal do enquadramento em seus fatores espaciais, temporais e também o contrato analítico formal (horários, honorários, férias, dentre outros) e o papel interpretativo do analista.

O enquadre deve ser mantido "ativamente" (Bleger, 1967, p. 313) pelo analista como uma invariante, pois, por mais que sua preservação sugira menos uma alternativa frente à problemática da estabilidade ideal do que uma questão de princípio, da qual Bleger não abdica (Leivi, 2002), o argumento do autor vai no sentido de que “...o enquadramento só pode ser analisado dentro do enquadramento..." (Bleger, 1967, p. 324. Grifos do autor). Assim, por mais que a intocabilidade do enquadre indique um problema em curso, quando ele se torna parte do processo a tendência é interpretá-lo de modo a realocá-lo segundo sua propriedade original de ser invariável. Deste modo, o enquadre é tomado como uma “...entidade viva e em transformação..." (Figueiredo, 2011, p. 140), mas que 
não se dispersa de sua configuração de base indispensável ao desenvolvimento do processo.

Numa leitura bastante inovadora tal como a de Bleger (1967), entrementes, podemos reconhecer duas vertentes distintas (Leivi, 2002) na compreensão do enquadre. A primeira, metodológica, visa estrategicamente a investigação do processo que só pode se dar a partir da manutenção de determinadas constantes. Tal vertente comporta o paradoxo (Leivi, 2002) de as constantes serem necessárias, porém constituírem um impasse ou uma "completa imobilização" (Leivi, 2002, p. 139) se não puderem se transformar em variáveis passíveis de serem analisadas, isto é, se não puderem se inserir em algum momento no processo (Bleger, 1967). A segunda vertente, metapsicológica, é correlativa ao não-eu no estágio de indiferenciação com o objeto primário, base sobre o qual emergirão o eu e a identidade do indivíduo (Bleger, 1967). Nesta segunda concepção, o enquadre é entendido paralelamente à "simbiose" (Bleger, 1967, p. 313) cuja organização onipotente só é fissurada no momento em que a mãe falha ou se ausenta, mas que permanece viva, ainda que muda e clivada na parte psicótica da personalidade. Presente, portanto, em todos os pacientes, os resquícios simbióticos são repetidos e reproduzidos sobre a estrutura do enquadre e se tornam perceptíveis somente quando este ameaça se romper.

O enquadramento " $e$ " a parte mais primitiva da personalidade, é a fusão ego-corpo-mundo, de cuja imobilização depende a formação, existência e discriminação (do ego, do objeto, do esquema corporal, do corpo, da mente, etc., etc.). Os pacientes com "acting in" ou os psicóticos trazem também "seu próprio enquadramento": a instituição de sua relação simbiótica primitiva, mas todos os pacientes também a trazem. (Bleger, $1967: 318$. Grifos do autor)

Assim, a vertente metapsicológica remonta aos aspectos simbióticos que são depositados no enquadre como num "mundo fantasma" (Bleger, 1967, p. 313) preenchido pela “...organização mais primitiva e indiferenciada” (Bleger, 1967, p. 313), tal como o amálgama inicial mãe-bebê antecedente à instauração do eu e ao reconhecimento do outro como tal. Esta leitura do não-processo como correlata do não-eu lembra a tese winnicottiana da fusão primordial mãe-bebê num ambiente de holding necessário à constituição egoica, sendo, portanto, através do setting que o paciente irá buscar as fases mais iniciais do desenvolvimento e assim resgatar aspectos relacionais a princípio inacessíveis pelo processo (Safra, 1995). 
Deste modo, se o que é depositado no enquadre permanecer mudo, sem adentrar o processo, os elementos mais primitivos e clivados permanecerão não analisados e não elaborados, trazendo impasses à continuidade do próprio processo analítico. Nos comentários de Figueiredo (2011):

Uma decorrência é a de que para a análise prosseguir além de certo ponto, o próprio enquadre precisará ser tomado em consideração para que então possam ser de ali desalojados e analisados aspectos até então ali escondidos e mantidos em estado de latência. Ou seja, é preciso que, a cada momento, o enquadre mantenhase firme - que as regras do jogo sejam bem estabelecidas e sustentadas, os limites bem definidos -, mas que sempre haja alguma flexibilidade, alguma elasticidade para que, no seu devido tempo, a análise ganhe terreno sobre o material até então imobilizado no enquadre. (Figueiredo, 2011 : 139-140)

Caso as constantes jamais se transformem em variáveis, paciente e analista incorrerão no risco de uma pseudo-análise tal como a descrita por Winnicott (1960b) nos padrões do falso self - em que o núcleo do verdadeiro self permanece oculto e intocado -, e por Baranger \& Mom (2002 [1982]) quando a queda do baluarte não é efetuada. Assim, uma análise baseada somente no processo - que não alcança os elementos depositados no não-processo - tem como resultado nada mais que um eu moldado num "caráter psicanalítico" (Bleger, 1967, p.320) através de um conluio (Damous, 2012) firmado entre paciente e analista num enquadre viciado:

Consequentemente, se nunca convertido em objeto de análise, o material psíquico clivado estabiliza-se na compulsão à repetição e o resultado que se conseguirá obter nessa análise será apenas a organização de uma personalidade adaptada, uma "fachada" ou o que se chama de eu "fático" ou ainda de "eu de pertinência" (Bleger, 1967 : 321). Produz-se nessas circunstâncias um pacto, isto é, um conluio entre o analista e seu paciente no sentido de manter o enquadre constante, intocável, imobilizado. (Damous, 2012b : 74)

Neste sentido, a observância do enquadre constitui-se como a mais perfeita compulsão à repetição, já que “...a mais completa, a menos conhecida e a mais inadvertida", além do “...'baluarte' mais persistente, tenaz e oculto...” (Bleger, 1967, p. 315-16) porque silenciado nos contornos de um enquadre que se mantém intocado. Por outro lado, no momento em que as constantes se transformam em variáveis, o enquadre se torna perceptível e se faz sentir, tal como o corpo, que silencia na saúde e reclama na doença (Green, 1988 [1975]). Correlativamente, 
são colocados em questão os elementos mais silenciosamente presentes na constituição subjetiva - a princípio corporais -, que permanecem vivos, ainda que imperceptíveis, e que só se tornam analisáveis através da quebra do enquadre, sobretudo quando esta é feita pelo próprio analista.

As rupturas inevitavelmente efetuadas no enquadre, tais como um atraso, o não-cumprimento de um determinado horário, férias ou qualquer eventualidade que produza uma "fresta" (Bleger, 1967, p. 318) através da qual se introduza elementos da realidade - para além do "mundo fantasma" do paciente produzirão efeitos de desmentido da fusão primitiva que se repete sobre as bases do enquadre. Nestes momentos, o fundo se transforma em figura, como na Gestalt, e o que há é uma situação sempre "catastrófica” (Bleger, 1967, p. 318), já que o "mundo fantasma" do paciente fica momentaneamente sem depositário.

Nos casos de psicose, mais ainda, uma pequena ruptura do enquadre pode se transformar numa enorme calamidade já que “...desorganiza-se o 'meta-ego' que, em grande medida, é tudo o que tem." (Bleger, 1967, p. 317. Grifos do autor.). Nos casos-limite, em que podemos contar com uma estrutura mais além de um "meta-ego" (Bleger, 1967, p. 317), isto é, uma com uma estruturação egoica ainda que desorganizada e com fronteiras mal delimitadas, a ruptura do enquadre por parte do analista também pode resultar numa grande intempérie, já que a relação estabelecida com o enquadre está diretamente associada aos cuidados ambientais primários e à constituição dos limites psíquicos (Damous, 2012), ambos frágeis e suscetíveis desde sempre.

Embora Bleger (1967) não se ocupe dos ataques ao enquadre nos casoslimite, formulamos que tais ataques sugerem uma forma de o paciente encenar a precariedade presente nas bases de sua constituição egoica. Assim, o ataque ao enquadre seria uma maneira de reproduzir ou denunciar a estrutura desde sempre fissurada sobre a qual o eu se "meta-constituiu”, ou, ainda, de “...procurar os próprios limites" (Damous, 2012, p. 78) ao invocar os limites da analisabilidade (Green, 1988 [1975]) via ataques ao enquadre. Neste sentido, Bleger (1967) nos auxilia, ainda, com uma compreensão do ataque enquanto representativo do que coexiste na organização egoica:

Creio ser apressado falar sempre de um "ataque" ao enquadramento quando este não é cumprido pelo paciente. O analisando traz "o que tem" e não se 
trata sempre de um ataque, mas de sua própria organização (mesmo que seja desorganizada). (Bleger, $1967: 326$ )

Assim, uma das formas de se entender os ataques ao enquadre é em virtude da própria organização subjetiva do paciente, a partir de tudo o que se torna insuportável, logo passível de ataque, no encontro com as delimitações do enquadre e do método analítico. A precariedade dos limites intrapsíquicos e intersubjetivos, ao se chocarem com os limites da clínica, impõem restrições ao método e nos motivam a buscar transformações e inovações capazes de sustentar o tratamento de um paciente tal como ele se nos apresenta - daí as preocupações atuais (presentes, sobretudo, na literatura francesa) se o que se faz nos consultórios e nas instituições é psicanálise ou se mereceria o nome de uma psicoterapia feita por psicanalistas e mais condizente, talvez, com os pacientes atuais (Green, 2002).

Em termos blegerianos, é somente através das rupturas que uma análise do enquadre se torna possível, algo indispensável para se chegar a um conhecimento do inconsciente mais profundo, efetuar a “...dessimbiotização da relação analistapaciente...” (Bleger, 1967, p. 322) e “...restabelecer a simbiose original, mas justamente por modificá-la.” (Bleger, 1967, p.324). Todavia, Bleger (1967) não nos oferece nenhuma indicação técnica de como realizar uma análise do enquadre (Donnet, 2005 [1973]), alertando-nos somente para as fortes resistências que se erguem frente à emersão do conteúdo clivado:

A dessimbiotização da relação analista-paciente só é alcançada com a análise sistemática do enquadramento no momento oportuno. E com isto nos confrontaremos com as resistências mais tenazes, porque não se trata de algo reprimido, mas clivado e nunca discriminado; sua análise abala o ego e a identidade mais madura atingida pelo paciente. Não se interpreta o reprimido; criase o processo secundário. Não se interpreta sobre lacunas mnêmicas, mas sobre o que nunca fez parte da memória. (Bleger, 1967 : 322)

Neste ponto, o que Bleger (1967) entende como dessimbiotização traz de volta a nossa questão, numa leitura winnicottiana, de os ataques ao enquadre nos casos-limite empreenderem tentativas de passagem para o campo do uso do objeto (Winnicott, 1969 [1968]), já que a relação com o objeto nos casos-limite ainda se dá, prioritariamente, pela vertente do subjetivamente concebido (Winnicott, 1969 [1968]; Garcia \& Damous, 2008). 
$\mathrm{Na}$ clínica limítrofe, portanto, em que a destrutividade adquire característica central (Winnicott, 1969 [1968]; Green, 2002), os ataques ao enquadre terão de ser pensados também através dos aspectos transferenciais que, dirigidos ao analista, sugerirão não somente a necessidade de comprometimento com a técnica do holding (Winnicott, 1955-56), mas também com sua sobrevivência perante os ataques destrutivos (Winnicott, 1969 [1968]). É neste sentido que uma descrição clínica deverá ser buscada, a fim de chegarmos, na sequência, ao nosso objetivo final. 


\section{5. \\ Os ataques ao enquadre e o uso do objeto na clínica dos casos-limite}

Na clínica dos casos-limite, o enquadre e o método analíticos têm de ser repensados em função das intensas regressões que estes pacientes efetuam (Winnicott, 1954; 1955-56), porém não somente. Assim como o ambiente suficientemente bom dos primórdios não é percebido ou lembrado (Winnicott, 1957; 1960a), refletindo numa clínica que pode seguir seu curso sem maiores reivindicações ao setting, nos casos-limite, por outro lado, o enquadre faz sentir sua presença em virtude de um ambiente original intrusivo ou, numa leitura greeniana, em função do objeto que não se deixou esquecer (Green, 1988 [1975]; 2010 [1988]).

O objeto demasiadamente presente suscita as angústias de intrusão e separação, em que o objeto é sentido ora como extremamente invasivo, ora como inalcançável e abandonador (Green, 1988 [1975]). Tal situação é transposta, evidentemente, para a relação transferencial, que por sua vez adquire um padrão instável e oscilatório no âmbito dos afetos (Figueiredo, 2003a). Neste ponto, os ataques ao enquadre sugerem uma tentativa atuada de expulsão do objeto primário que se tornou excessivo na esfera psíquica, dramatizando na relação com o analista a necessidade de constituir o espaço interno da ausência ou uma distância eficaz entre o eu e o outro.

Considerando que as fronteiras intersubjetivas não estão bem instaladas, as intensas identificações projetivas que emergem na clínica como efeito da clivagem tornam a confusão eu-outro ainda mais crítica, já que os conteúdos internos são tomados como provenientes do objeto (Figueiredo, 2003a). Consequentemente, os ataques ao enquadre configuram ainda uma defesa contra tais conteúdos que, por parecerem vir de fora do sujeito, agravam as vivências de intrusão e perseguição, combatidas, sobretudo, na esfera do ato.

Em nossa leitura, para além de uma encenação das fronteiras mal delineadas eu-outro, transcendendo ainda o âmbito dos mecanismos de defesa, os ataques ao enquadre constituiriam a busca pelo objeto almejando sua externalidade, isto é, seu caráter de realidade na esfera social compartilhada, só 
possível de se efetivar após a destruição do objeto subjetivamente concebido - e, imprescindivelmente, a sobrevivência do objeto-analista. Neste caminho, a clínica se deparará com transferências paradoxais (Roussillon, 1999a; 2002a) e intensas manifestações de ordem agressiva que sugerirão, por sua vez, a tentativa de destruição do objeto-analista e a conquista clínica do uso do objeto (Winnicott, 1969 [1968]).

\section{1}

\section{A clínica dos casos-limite: aspectos transferenciais}

Tal como, no início da psicanálise, a clínica da histeria tornou inteligíveis os processos psíquicos envolvidos no adoecimento psicológico - levando inclusive a uma teoria geral do funcionamento psíquico -, é a clínica dos casoslimite que instrumentaliza uma compreensão metapsicológica que vem, em contrapartida, fundamentar e confirmar sua aplicabilidade prática, garantindo-lhe um respaldo teórico. Assim, o ponto de partida de inúmeras construções teóricas contemporâneas reside em experiências clínicas que estendem o conhecimento para além do campo da neurose, possibilitando um novo olhar sobre a prática cotidiana.

Muito frequentemente, a clínica dos casos-limite é descrita em comparação à clínica da neurose, sobretudo em função das diferenças que explicitam os limites da analisabilidade (Green, 1988 [1975]) ao colocar em xeque, grosso modo, o papel interpretativo do analista e a regra fundamental da associação livre. Em Freud $(1920 ; 1923 ; 1924)$, já temos notícias de situações refratárias à aplicabilidade do método, porém no contexto de análise dos casos-limite são questionados os parâmetros clínicos ou até mesmo os limites de sua pertinência (Donnet, 1999) através de uma transferência que se desenvolve de modo paradoxal (Roussillon, 1999a; 2002a) - podendo ser acrescida de aspectos delirantes (Little, 1981 [1958]; Rosenfeld, 1989; Roussillon, 2002b) - e dos frequentes ataques ao enquadre (Green, 2010 [1988]; André, 1999; Figueiredo, 2003b; Garcia, 2010 [2007]; Damous, 2012a; 2012b). 
Enquanto que a clínica da neurose funda-se sobre a tríade neurose infantil - neurose adulta - neurose de transferência, nos casos-limite o que vigora é a “...ausência de neurose infantil, o caráter polimorfo da chamada 'neurose' adulta em tais casos e a obscuridade da neurose de transferência" (Green, 1988 [1975], p. 44). Aqui, a transferência pode evoluir desde o extremo do "antianalisando" (McDougall, 1972 apud Green, 1988 [1975], p. 44), em que o analista está excluído de um investimento libidinal, logo a transferência é "natimorta" (Green, 1988 [1975], p. 44), até o extremo oposto da regressão fusional, em que o paciente desenvolve uma dependência capaz de ir da “...beatitude ao terror e da onipotência à total impotência” (Green, 1988 [1975], p. 44), invocando relações tanto idealizadas quanto persecutórias.

Ainda que as condições de análise sejam bastante desfavoráveis na clínica borderline, os limites da analisabilidade, de uma maneira geral, tornam-se mais interessantes se pensados em função das situações-limites (Roussillon, 1991; Damous, 2012a, p. 95) que podem ser vividas em qualquer tratamento, mais do que vinculados restritivamente a uma entidade nosográfica, isto é, a despeito de um diagnóstico específico. No entanto, nos casos-limite, a precariedade dos limites intrapsíquicos e intersubjetivos (Green, 1990 [1986]) funciona como um agravante que faz com que as situações-limites sejam experimentadas intensamente no tratamento, já que a incerteza dos limites recai sobre a possibilidade de uso do enquadre e do método analíticos. Nos comentários de Damous (2012a):

\footnotetext{
...os casos-limite especialmente vivenciam um modo tal de funcionamento psíquico que intensa e maciçamente os levará a impingir esses estados-limites da analisabilidade colocando em questão não apenas o enquadre, a regra fundamental e a interpretação analítica, mas também organizando certas configurações transferocontratransferenciais e igualmente fazendo advir com frequência a reação terapêutica negativa. (Damous, 2012a : 99)
}

Neste contexto, a questão dos limites incide sobre a própria transferência, que adquire características singulares na medida em que as fronteiras entre o eu e o outro não estão asseguradas. A neurose de transferência, tal como estipulada por Freud $(1914 ; 1916-17)$ como indispensável à instauração da análise, pressupõe a capacidade de o indivíduo investir libidinalmente em objetos diferentes do eu, sobretudo com base na configuração edípica. Ora, se nos casos-limite as 
delimitações intersubjetivas encontram-se prejudicadas, atestando o comprometimento da diferenciação primária eu-objeto (André, 1999; Cardoso, 2010 [2005; 2007]), como será possível, na clínica, o analista ser investido transferencialmente, representando um objeto antigo mas já considerado em sua alteridade, como parece ter sido o entendimento de Freud?

Pressupondo as falhas graves ocorridas nos cuidados ambientais com estes casos (Winnicott, 1955-56), somos levados de uma clínica da terceiridade - em que há a referência a um terceiro - a uma clínica dual, em que a regressão à dependência será experimentada com acuidade máxima e os cuidados ambientais primários serão evocados no e através do setting analítico (Winnicott, 1954; 1955 56). Neste contexto, o terceiro elemento está ausente, e a relação analítica se dá entre o paciente (bebê) e o analista (cuidados maternos), ou ainda na indiferenciação entre ambos, dado o estado fusional engendrado em uma regressão à dependência absoluta (Winnicott, 1954). Nestas circunstâncias, a repetição será aquela de uma carência (Thompson, 2002) que na realidade foi vivida como uma invasão (André, 1999).

Para Green (1988 [1975]), trata-se sempre de uma questão do excesso, remetendo ao pulsional que não pôde ser contido pelo objeto que falhou em cumprir sua dupla função de estimular e conter a pulsão (Green, 2010 [1988]). O objeto permaneceu absoluto ao não se deixar apagar, atestando o fracasso do trabalho do negativo que impossibilita a construção do espaço da ausência no psiquismo, trazendo consequências à formação do pensamento e à construção de representações (Green, 2010 [1986; 1988]). Deste modo, foi impossível estabelecer uma estrutura enquadrante (Green, 2002) enquanto um espaço potencial interno que possibilitasse a representação e o investimento subsequente de novos objetos, deixando o indivíduo enredado na trama inicial com o objeto primário. As consequências clínicas serão vistas, sobretudo, através da dupla angústia caracterizada por angústias de intrusão e separação, mais do que pela angústia de castração tal como comumente experimentada nas neuroses (Green, 1988 [1975]; 1999; 2002).

As angústias de intrusão e separação são tomadas clinicamente como efeitos subjetivos da relação com um objeto que se tornou excessivo tanto por sua presença maciça quanto por sua ausência demasiada. Seja pela ausência ou pela presença exageradas, o objeto primário constituiu-se como um objeto tanto 
dominador e engolfante quanto nulo e abandonador, de todo modo incapaz de organizar as demandas pulsionais que são de início impossíveis de ser metabolizadas pelo sujeito ele próprio. Em ambos os casos, a relação com o objeto excessivo traz à tona não a questão do desejo, mas da formação do pensamento (Green, 1988 [1975]), a intrusão provocando um sentimento delirante de influência e a inacessibilidade do objeto impedindo qualquer forma de presença imaginária ou metafórica. Deste modo, o objeto torna-se um elemento aterrador que incide sobre a capacidade de simbolização justamente pelo fato de jamais se ausentar do espaço psíquico de modo satisfatório, trazendo consequências a uma clínica que se propõe a trabalhar sobre o campo transferencial elaborativo e simbolizante.

...De fato, podemos supor que a inundação do espaço psíquico por um excesso pulsional evoca angústia de intrusão à qual o sujeito reage defensivamente com o desinvestimento e a ruptura dos vínculos libidinais. Isto, por sua vez, suscita a angústia de separação e o sentimento de vazio. Em ambas as situações o resultado é o mesmo: paralisia do processo de simbolização e vazio afetivo, que impossibilitam a realização do trabalho psíquico indispensável à continuidade de uma análise. (Garcia, 2010 [2005] : 75)

Deste modo, tanto a inacessibilidade do objeto sempre ausente quanto a invasão incessante do objeto que jamais se ausenta adquirem características de um excesso que se reproduz na clínica, impondo sérios problemas técnicos e metodológicos. Se o analista interpreta, está repetindo a intrusão do objeto onipresente, restando num lugar insuportável porque invasivo e persecutório. Se se mantém em silêncio, não faz mais do que repetir o abandono do objeto inacessível, relegando o paciente à sua própria sorte ou, mais precisamente, ao seu “deserto objetal” (Green, 1999, p. 39).

...Confrontado com este cenário o analista se vê diante do impasse entre preencher o espaço analítico com interpretações - o que apenas agrava o sentimento de intrusão - ou suportar o silêncio e o vazio - o que pode se configurar como uma ameaça de morte psíquica para o paciente. (Garcia, 2010 [2005] : 75)

O eu se encontra, portanto, marcado pela dupla angústia que por sua vez suscita defesas e contrainvestimentos frente a um objeto que ameaça pela dupla via da intangibilidade e da perseguição. $\mathrm{O}$ objeto jamais presente acarreta uma idealização pelo fato de sua indisponibilidade, e o objeto permanentemente 
presente torna-se mau e persecutório, mas sem o qual não se pode viver (Green, 1988 [1975]).

A “...necessidade de manter uma relação com um objeto mau, a todo custo" (Green, 1988 [1975], p. 60) evita que o sujeito se confronte com um vazio aniquilante, onde ele se veria num deserto desprovido de objetos. Assim, quando o objeto mau ameaça perder seu poder, o sujeito o faz reaparecer, instaurando um ciclo de "destruição e reaparecimento" (Green, 1988 [1975], p. 60) impossível de ser modificado pela presença de um objeto bom, de qualquer modo indisponível. Assim, o eu tem de manejar a sobrevivência de suas fronteiras extraordinariamente porosas e ao mesmo tempo extremamente sensíveis à intrusão (Green, 1999), empreendendo tentativas de expulsar o objeto mau sem vislumbrar, no entanto, o preenchimento do espaço pessoal com a representação de um objeto bom. Caso o objeto mau desaparecesse, isto colocaria em xeque a existência do próprio sujeito, aspirando-o igualmente à nulidade, implicando em “...possibilidades aterrorizadoras de morte e dissolução.” (Figueiredo, 2003a, p. 82). Nas palavras de Green (1988 [1975):

\begin{abstract}
...O objeto é mau, mas é bom que exista, muito embora não exista como um objeto bom. (...). Contudo esta repetição compulsiva é devida ao fato de que aqui a vacuidade só pode ser catexizada negativamente. $\mathrm{O}$ abandono não leva à catexia de um espaço pessoal mas a uma aspiração atormentadora à nulidade que arrasta o paciente a um buraco sem fundo e, eventualmente, a alucinações negativas de si próprio. (Green, 1988 [1975] : 60)
\end{abstract}

Deste modo, as consequências da inexistência de um espaço de ausência no psiquismo - ou estrutura enquadrante - se fazem sentir clinicamente, não havendo como recorrer a um espaço pessoal capaz de ser habitado pela representação de um objeto ambivalente, ora bom, ora mau. Aqui, a valência bommau torna-se absoluta, e o analista é tido como "só presente - só ausente"; "tudo bom - tudo mau" (Figueiredo, 2003a, p. 87).

O mecanismo de defesa da clivagem, preponderante nestes casos (Green, 1988 [1977]; Roussillon, 1999; Figueiredo, 2003; Cardoso \& Garcia, 2010), demonstra a precariedade do conflito intrapsíquico e a incapacidade de suportar ambivalências. Neste contexto, são suscitadas defesas e angústias que adquirem um padrão instável e oscilatório, sendo comuns as variações intensas de humor e as mudanças bruscas na forma de se conceber o objeto: 
...Para esses pacientes, ou os objetos aparecem e desaparecem subitamente (como que lembrados e esquecidos alternadamente), ou trocam subitamente de valor afetivo, sendo que em cada extremo da escala bom-mau a valência tende a se absolutizar. Portanto, ora parecem estar operando vínculos de dependência extrema diante de objetos muito bons, ora esses vínculos parecem nunca ter existido ou parecem estar sendo furiosamente renegados diante de péssimos objetos. (Figueiredo, 2003a : 86)

A impossibilidade de vivenciar o conflito e a ambivalência em função das clivagens e dissociações intensifica a fragilidade do $\mathrm{eu}$, instaurando um círculo vicioso que mantém o paciente distante de alcançar uma coesão egoica. Consequentemente, a percepção da realidade em sua estruturação complexa também se encontra prejudicada, sendo tomada de forma simplificada tal como o padrão de relacionamentos pautados nos extremos "tudo ou nada" (Figueiredo, 2003b, p. 116. Grifos do autor.):

\begin{abstract}
...Em outras palavras, a realidade não é admitida à consciência em sua complexidade ambivalente, mas detectada em uma de suas facetas para, logo em seguida, ser construída de uma forma enviesada e colorida por um humor dominante que simplifica e homogeneíza. Os afetos são assim intensificados, pois lhes falta a moderação e o equilíbrio que o conflito poderia propiciar. Os pacientes borderline fogem do conflito como o diabo da cruz, pois sentem que sua estrutura subjetiva e sua integridade egóica estão por um fio... (Figueiredo, 2003b : 117-18)
\end{abstract}

Demasiadamente intensos, os afetos - que vão desde paixões idealizadoras e impulsos coléricos até um total rebaixamento e congelamento afetivos implicam em fortes demandas contratransferenciais, já que o borderline "...toca e solicita o analista em regiões obscuras e confusas de sua mente e de seu corpo, gerando afetos pouco disciplinados e inteligíveis." (Figueiredo, 2003b, p. 111). A aderência do paciente é sentida pelo analista como uma tentativa de colonização de seu espaço psíquico, sendo ele colocado igualmente numa condição fronteiriça, já que seus limites egoicos ficam mais frágeis ou até mesmo indefinidos (Coelho Jr. \& Getlinger, 2006). Por essas e outras, a clínica dos casos-limite é considerada, ela própria, uma clínica limítrofe (Figueiredo, 2003b).

Em tais condições, o setting terá de ser remodulado de modo a se trabalhar com elementos pouco familiares à clínica tradicional, tais como as grandes demandas de implicação feitas pelo paciente borderline, que... 
...exigem uma atenção constante, uma prontidão de resposta, uma sustentação verbal e mesmo física que ameaçam esgotar todas as nossas reservas. Eles nos chamam para um "aqui e agora" desesperado no qual, sob o impacto da urgência da demanda de implicação, corremos o grande risco de perder completamente a posição do analista. (Figueiredo, 2008a : 37. Grifos do autor.)

A "modulação" (Figueiredo, 2003b, p. 110) do enquadre consiste na preservação de aspectos essenciais - a serem mantidos em qualquer análise somada a uma maleabilidade operacional mais ampla, tão possível quanto maior a elasticidade das fronteiras egoicas do analista. Assim, a modulação se dá, sobretudo, no âmbito do enquadre interiorizado pelo analista (Green, 2000), alternando-se em formas de presença ora implicada, ora reservada (Figueiredo, 2003b; 2008a).

A presença reservada consiste numa "ausência convidativa" ou "reserva de si para o outro" (Figueiredo, 2008a, p.24-25. Grifos do autor.) - o que implica em disponibilidade e confiabilidade -, ao passo que a presença implicada consiste em disponibilizar sua pessoa real para determinados usos e criações do paciente. Assim, quanto maior a elasticidade e a permeabilidade egoicas, mais o analista poderá intercalar as modalidades de implicação e reserva, sendo ainda capaz de receber os conteúdos clivados, metabolizando-os e transmitindo-os verbalmente para o paciente, quando possível. Isto, no entanto, só poderá se efetivar se ele mantiver preservadas suas reservas pulsionais e narcísicas - autolimitação, continência e relativa integração -, a fim de que as grandes demandas de implicação não o ocupem por inteiro, tampouco o subtraiam de sua função analítica (Figueiredo, 2003b).

Antes, porém, de o analista conseguir chegar a uma compreensão do que se passa internamente com o paciente, ele levará bastante tempo para compreender onde se localiza na trama transferencial, já que...

...será empurrado para dentro e para fora, para perto e para longe alternadamente devendo funcionar como aqueles bonecos (joões-bobos) que têm um lastro muito pesado na base arredondada e uma parte superior bem leve. Empurrado para trás e puxado para frente, consegue responder alternadamente a esses movimentos sem opor resistência, mas também, e na medida do possível, sem sair do lugar. (Figueiredo, 2003a : 94. Grifos do autor.)

É neste sentido que a contratransferência adquire papel fundamental, pois além de os casos-limite exigirem do analista uma contribuição pessoal maior 
(Green, 1988 [1975]), a contratransferência funciona também como indicador do que se passa com o paciente, mas que está aquém de sua capacidade de representar e/ou verbalizar. Deste modo, o analista terá de fazer grandes esforços imaginativos para compreender a dinâmica interna do analisando, tendo que emprestar seu aparelho de pensar (Green, 1988 [1975]; 1982; 1990 [1986a]) e suas funções egoicas (Coelho Jr. \& Getlinger, 2006) de modo a auxiliar a simbolização, objetivo primordial da instauração de um enquadre analítico (Green, 1988 [1975]).

Neste contexto da dupla angústia e de oscilações severas no plano afetivo, revela-se uma grande sensibilidade do paciente à presença do analista, ao que ele diz, ao seu modo de ser e se apresentar, mas também à sua ausência quando, por exemplo, o analista tira férias ou desmarca uma sessão. Um mero fim de sessão, inclusive, pode ser vivido como um abandono traumático (Green, 2002), explicitando a precariedade das dimensões da ausência e da transicionalidade que promoveriam uma dinâmica de separação-(re)união não-traumática.

As experiências são vividas, portanto, de forma invasiva e/ou aniquilante, e o analista é colocado tanto num lugar de objeto abandonador quanto sedutor, hostil e interessado, ineficaz e intromissivo, demasiadamente distante e excessivamente próximo. A complexidade da transferência aumenta com a tendência de o paciente alternar, ainda, as posições ocupadas por ambos: ora o paciente coloca o analista nos polos de objeto sedutor e rejeitador, ora ele próprio se identifica com tais posições, sendo, por vezes, aquele que seduz e rejeita. De todo modo, na clínica borderline, o dispositivo encontra-se sempre abalado pelo fato de paciente e analista frequentemente perderem seu lugar habitual de definição (André, 1999).

Os lugares ocupados por ambos se tornam confusos principalmente pelas identificações projetivas que dominam a transferência quando os limites egoicos não estão bem instalados. Na visão de Figueiredo (2003c), encontramos a seguinte definição para tal fenômeno:

...A identificação projetiva é, em primeiro lugar, embora não se esgote necessariamente nisso, uma fantasia por meio da qual partes do psiquismo do paciente são expelidas e colocadas sobre e dentro de seus objetos. Isso pode ocorrer seja para colocar para fora as partes boas e ameaçadas de destruição no interior de um psiquismo muito perturbado pelo ódio, pela inveja e pela culpa. Em ambos os casos, forma-se uma confusão entre o sujeito e seus objetos de identificação 
projetiva, com os quais o indivíduo estabelece relações narcisistas muito primitivas e resistentes à análise. (Figueiredo, 2003c : 140-41)

A identificação projetiva - que é uma forma de projeção primária (Coelho Jr. \& Getlinger, 2006) - está intimamente relacionada à dominância do mecanismo de defesa da clivagem. Neste sentido, já que não é possível contar com a barreira do recalque como balizadora dos conteúdos internos, os afetos de grande intensidade e as representações intoleráveis adentram o território do eu e da consciência sem passar pelo crivo dos limites psíquicos que deveriam operar como filtros. Como, de igual modo, as fronteiras entre o eu e o outro não estão bem asseguradas, a evacuação das angústias suscitadas pela invasão pulsional interna se torna o meio mais rápido, simples e eficaz de aliviar a tensão. Assim, o analista torna-se alvo de intensas demandas e identificações projetivas de ordem libidinal, tornando-se, em seguida, vítima de novas identificações projetivas de caráter agressivo e odioso, hostil e desprezivo.

Uma relação pautada nestes moldes coloca o analista na posição daquele que sente e pensa o que o paciente é incapaz de tomar como seus próprios conteúdos. Assim, ele deve estar disposto a receber os elementos clivados sem perder, todavia, suas “....reservas narcísicas capazes de sobreviver aos maus-tratos, 'confusões de pessoa', faltas de consideração, etc." (Figueiredo, 2003b, p. 123). Se o analista, por outro lado, não se mostra disposto a receber e metabolizar tais conteúdos, muito provavelmente não entrará em contato com a realidade psíquica do paciente, provocando sentimentos de rejeição e abandono.

As trocas se dão, portanto, num campo de comunicação primitiva em que a clivagem favorece as identificações projetivas e cria verdadeiros "fossos intransponíveis" (Coelho Jr. \& Getlinger, 2006, p. 155) entre afeto e representação e impossibilita a conexão das ideias, já que os elos de ligação estão destruídos (Green, 1988 [1977]). Tal como a imagem criada por Green (1988 [1977]) de um eu que mais se assemelha a um arquipélago de ilhas decompostas, o discurso do borderline também carece de coerência e coesão, restando ao analista a tentativa de reunir suas partes:

...O discurso do fronteiriço não é uma cadeia de palavras, representações ou afetos, mas, antes - como um colar de pérolas sem fio -, palavras, representações, afetos contíguos no espaço e no tempo, mas não em significado. Cabe ao observador 
estabelecer o elo que falta, com seu próprio aparelho psíquico. (Green, 1988 [1977] :85)

Deste modo, a associação livre fica comprometida, assim como a atenção flutuante e a interpretação. O paciente borderline, bastante "barulhento" internamente (Figueiredo, 2011), pode até ser um sujeito eloquente, mas nem por isso capaz de entrar em contato com a dimensão emocional e pulsional da experiência e do discurso em análise. A loucura privada (Green, 1990) permanece em atividade, atuando de forma primitiva e ressoando no analista que se mantém atento ao que seria, a princípio, inaudível.

Para Roussillon (1999a), em consonância com sua teoria do traumatismo primário presente nos sofrimentos narcísico-identitários, o paciente faz com que o analista sinta aquilo que ele é incapaz de sentir em si próprio, já que o traumatismo primário redundou em conteúdos clivados e alheios ao eu, impossibilitados de ser apropriados subjetivamente. As falhas graves do ambiente e a impossibilidade de se contar com recursos internos satisfatoriamente supridores prejudicaram a simbolização primária, certas experiências restando estranhas - irrepresentáveis, irreconhecíveis - ao próprio sujeito. Neste contexto, trata-se mais de uma questão de algo que não adveio do que daquilo que um dia pertenceu ao indivíduo e foi perdido.

Na clínica, aquilo que o paciente não sente, não sofre, não ouve dentro de si é evocado no analista de forma irreconhecível em substituição ao conflito psíquico percebido subjetivamente, situação clínica que se apresenta como uma forma paradoxal de transferência (Roussillon, 1999a; 2002a). Neste caso, no lugar do conflito subjacente à lógica do recalque, os conteúdos clivados deslancham fenômenos compulsivos perante os quais nenhum compromisso é possível, instaurando impasses na situação analítica. Neste contexto, não se trata de possibilidades de escolha - ou do direito de não escolher -, mas de pura compulsão à repetição para além do princípio do prazer, e o que poderia ser vivido como estados de luto ou renúncia desemboca em sentimentos de desespero, desamparo e retraimento.

A transferência paradoxal é permeada de estados de agonia, já que atualiza - de maneira clivada da organização psíquica manifesta - um desespero existencial da ordem do traumatismo primário (Roussillon, 2002a). A clivagem, 
no entanto, demonstra suas limitações na tarefa de conter internamente o que não foi simbolizado, entrando em cena, então, as tentativas de ligação não-simbólica tais como as somatizações, as toxicomanias, a neutralização energética - nãoinvestimento objetal a fim de evitar a zona traumática -, as soluções grupais/ institucionais, o masoquismo ou fetichismo em forma de co-excitação libidinal tentativa de integrar a situação traumática com o auxílio de excitações sexuais desta ordem -, podendo haver ainda saídas delirantes em que o vivido atual subverte a historicidade do que não foi simbolizado primariamente (Roussillon, 1999a). Aqui, embora as atuações figurem uma positividade através do ato, a transferência se refere mais às problemáticas da negatividade do que à sua possibilidade de circunscrever processos de integração e ligação via relação objetal. O que não foi perdido porque jamais inscrito simbolicamente, bem como a particularidade de seus efeitos serem sentidos no analista, colocam-no no lugar de "espelho do negativo do analisando" (Roussillon, 1999a; 2002a), a transferência operando mais por reversão que por deslocamento.

A transferência por reversão é outra forma de conceber a transferência paradoxal - esta última, Roussillon pega emprestado de Anzieu (1975) -, e que difere da transferência padrão, que opera via deslocamento afetivo e representacional de objetos significativos da história do paciente. $\mathrm{Na}$ análise dos sofrimentos narcísico-identitários, também encontramos transferências por deslocamento, porém as paradoxais são mais comuns e nelas o processo de reversão invoca uma "dupla carga paradoxal" (Roussillon, 2002a, p. 18) que desafia ainda mais a escuta clínica. Pois, se a transferência por deslocamento já sugere um paradoxo em sua natureza mesma de conceber, no analista, uma reedição de fragmentos do passado, a transferência por reversão duplica o paradoxo, tornando o analista aquele que sente ativamente o que o sujeito viveu passivamente:

De um lado, o analista tem relativamente boas razões para ouvir, na transferência que se estabelece na situação analítica, formações transferenciais dominadas pelo processo de deslocamento.... Porém, do outro lado, e de maneira clivada, uma outra transferência, um outro processo transferencial vem duplicar o primeiro, sem antagonismo manifesto, no qual o analista é posto no lugar da criança que o analisando foi frente a seus objetos e, singularmente, daquilo que ele teve de repudiar de si mesmo para manter a relação narcísica com os mesmos. (Roussillon, 2002a : 18-19. Grifo do autor.) 
Neste contexto, se a análise se resume à escuta da transferência por deslocamento, como no tratamento padrão, possivelmente a situação analítica irá se defrontar com uma “...imobilização do processo analítico..." (Roussillon, 2002a, p. 19). Tal como observado pelos Baranger (1961-62), a situação analítica enquanto campo dinâmico pagará o preço das resistências compartilhadas que mantêm intocado o baluarte, impedindo o prosseguimento do processo. Se o analista lança mão de interpretações desconsiderando a dinâmica reversiva - e, portanto, os indicadores contratransferenciais, mais do que aquilo que se escuta enquanto discurso -, as interpretações ou se tornarão inutilizáveis (Little, 1981 [1958]) e sem sentido em sua tarefa simbolizante e mutativa, ou intensificarão ainda mais as experiências subjetivas não simbolizadas, ao se confrontarem diretamente com os conteúdos clivados, reafirmando seu caráter persecutório porque ainda sentidos como externos ao sujeito.

Na dinâmica dos conteúdos clivados que invadem a situação analítica, as esferas da percepção e da sensação (Roussillon, 1999a; 2002a) tomam a dianteira, dada a precariedade do âmbito representacional, do conflito subjetivo e da construção fantasmática que auxilia a transformar e elaborar os acontecimentos traumáticos reais (André, 2002). O que poderia ser tomado como representação adquire mais o estatuto de percepção; e o afeto, mais do que emoção propriamente dita, transfigura-se em sensação, ambos - sensação e percepção - invocando mais uma função interativa do que introspectiva. Daí decorre uma confusão entre representação e alucinação na cadeia associativa, trazendo consequências para a relação estabelecida tanto com a realidade interna quanto externa (Roussillon, 2002a). É com a constatação de uma fenomenologia clínica nestes moldes, aliás, que alguns autores (Little, 1981 [1958]; Rosenfeld, 1989; Roussillon, 2002b; Thompson, 2002) preferem designar a transferência nos casos-limite como delirante ou como uma psicose de transferência, em substituição à neurose de transferência.

A transferência delirante consiste, essencialmente, na colocação em cena das experiências não apropriadas subjetivamente, não simbolizadas, impossíveis de adquirir representação psíquica (Roussillon, 2002b). Sua dinâmica ganha corpo num fenômeno circunscrito dentro dos limites do enquadre, num ambiente de segurança e confiabilidade onde poderá emergir a loucura pessoal (Green, 1990). A transferência delirante ou a loucura pessoal/privada instaura uma confusão eu- 
outro através de profundas regressões e fusões, com a característica de tomar o presente da relação transferencial de forma irredutível e a-histórica. Nesta perspectiva, a vivência do paciente torna a relação analítica resumida a ela mesma, sem o caráter metafórico ou a qualidade de "como se" (Baranger, 196162; Little, 1981 [1958]) comumente engendrada na situação analítica ou na transferência neurótica. Neste contexto, embora a análise não seja totalmente privada da transferência por deslocamento, a objetividade do analista se sobrepõe a toda forma de representatividade que dignifica sua função de representar um objeto da história do paciente e que torna o enquadre um dispositivo de simbolização, um espaço-tempo transicional entre o passado histórico e a relação atual analista-analisando.

Numa coletânea dedicada ao estudo da transferência nos casos-limite, em que os artigos se entrecruzam em torno do relato da análise pessoal de Margaret Little com Winnicott (de 1949 a 1955-56), Roussillon (2002b) relembra o seguinte, no que tange à questão da objetividade/representatividade na clínica com estes casos:

\begin{abstract}
...M. Little diz ela mesma que uma característica dos momentos de transferência central neste tratamento é precisamente seu aspecto "delirante", quer dizer a dificuldade e a necessidade de diferenciar a representação da coisa ela mesma. (...). ...a coisa psíquica se dá por ela mesma e somente por ela mesma, sem ser subjetivável como uma representação psíquica. É isto que a formulação de Winnicott, retomada por M. Little, enuncia claramente: "O divã do analista não simboliza a mãe do analisando, ele é a sua mãe.” (Roussillon, 2002b : 42-45. Tradução nossa.)
\end{abstract}

Então, em função da tendência à regressão à dependência no paciente privado de um ambiente suficientemente bom nos primórdios (Winnicott, 195556), a situação analítica é tomada por uma nebulosidade dos limites egoicos e uma fusão com o objeto, que por sua vez se torna uma extensão do self narcisista do borderline: “...o paciente carece de um sentimento de identidade separado de seu analista...” (Repetto, 1986, p. 203).

O impasse entre as esferas da objetividade e da representação se estende para uma indiferenciação entre sujeito e objeto que a transferência delirante, por sua vez, esconde (Little, 1981 [1958]) ou, diferentemente, denuncia (Roussillon, 2002b): 
Realidade e representação, dentro e fora, eu e não-eu, sujeito e objeto não são mais portanto diferenciáveis, o sujeito está atormentado por uma desordem tanto do julgamento de atribuição quanto do julgamento de existência, por uma desorganização tópica que se traduz pela transferência delirante. (Roussillon, 2002b : 45. Tradução nossa.)

Neste contexto, a transferência delirante invoca uma problemática precedente à aquisição da linguagem e à configuração edípica, logo a interpretação do sexual deve ser evitada, em prol do acolhimento e da compreensão da confusão psíquica na qual o sujeito se encontra. $\mathrm{O}$ analista auxiliará o analisando a diferenciar entre aspectos históricos e atuais de modo a historicizar sua história não simbolizada, auxiliando na apropriação subjetiva dos elementos sentidos e experimentados, psíquicos porém não representados. Desta perspectiva, a questão do desejo inconsciente está - ao menos por enquanto - fora de alcance (Little, 1992 [1990]; Roussillon, 2002b), tratando-se mais de uma problemática relacionada à separação do objeto primário e à diferenciação eu- não eu (Repetto, 1986; André, 1999; Roussillon, 2002b; Cardoso, 2010 [2007]) que se atualiza na clínica, inevitavelmente.

No tratamento dos casos-limite, portanto, a predominância das identificações projetivas e a (con)fusão instaurada entre o eu e o outro corrompem o reconhecimento da alteridade do analista, que ocupa o lugar de objeto subjetivo (Roussillon, 2002a) ou objeto narcísico (Repetto, 1986; Figueiredo, 2003c). Isto devido à negação da separação e recusa da diferença (Figueiredo, 2003c) ou, em termos winnicottianos, à impossibilidade de conquistar o uso do objeto e relacionar-se com pessoas totais (Winnicott, 1969 [1968]). Nos comentários de Repetto (1986):

Basicamente se transfere uma relação de objeto primitiva com a mãe, na qual não se chegou a completar o processo de desmame. Situação que implica uma organização egoica que nunca alcançou um nível de diferenciação suficiente como para experimentar um sentimento de integridade de seu próprio eu ou vivenciar os objetos como pessoas totais. (Repetto, 1986 : 198. Tradução nossa.)

Nestas circunstâncias - bastante distintas daquelas a partir das quais o enquadre analítico foi construído por Freud -, a regra fundamental se transforma em exceção e a interpretação tem de ser suspensa, ao menos até que novas condições possibilitem a reorganização do enquadre padrão. 
Na clínica com os casos-limite, a situação analítica é, portanto, pervertida e desviada em seu uso e parâmetros habituais, tornando-se mais uma questão de passagem da condição de "inutilizabilidade do objeto" (Roussillon, 2002b, p. 56) para a conquista do uso do objeto na clínica (Winnicott, 1969 [1968]). Esta passagem é acompanhada, inevitavelmente, de frequentes episódios de destrutividade (Winnicott, 1969 [1968]) aos quais chamaremos de ataques ao enquadre (Green, 2010 [1988]; André, 1999; Figueiredo, 2003b; Garcia, 2010 [2007]; Damous, 2012a; 2012b), considerando aí os ataques à situação analítica em sua complexidade, o que inclui as demarcações de base do enquadre, o método analítico e a própria pessoa do analista.

\section{2}

\section{O enquadre que não se deixa esquecer: os ataques enquanto tentativas de passagem para o campo do uso do objeto}

Na clínica dos casos-limite, como vimos, a constelação transferencial está pautada, de um modo geral, na dupla angústia (Green, 1988 [1975]; 1999; 2002); nas oscilações repentinas dos afetos (André, 2002; Figueiredo, 2003a); nas grandes demandas de implicação do analista (Figueiredo, 2003b; 2008a); no predomínio de identificações projetivas que desembocam numa transferência paradoxal (Roussillon, 1999a; 2002a) e atestam os prejuízos representacionais (Green, 1988 [1975; 1977]); e na confusão instaurada entre paciente e analista, sempre pelo viés das fronteiras mal delimitadas intrapsíquica e intersubjetivamente.

No encontro com os limites da analisabilidade (Green, 1988 [1975]) suscitados por esta gama de fenômenos, o enquadre se torna um importante instrumento de diagnóstico (Green, 2002; Urribarri, 2010), constituindo não somente um pré-requisito à análise, mas também um meio de atestar o uso que o paciente pode ou não dele fazer enquanto ambiente facilitador (Winnicott, 195556; Green, 1988 [1975]; Urribarri, 2010). Por um lado, a função do enquadre de produzir simbolização se dá a partir da capacidade de associar livremente, refletindo a possibilidade de construir representações a serem interpretadas pelo analista. Neste aspecto, Green (1988 [1975]) sugere que uma teoria do enquadre 
seja pensada em termos de funcionamento mental, no qual os limites da analisabilidade são considerados através da tendência à atuação, das carências representacionais e elaborativas e da destrutividade dirigida aos processos de pensamento (Green, 2002). Por outro lado, a capacidade de investir transferencialmente o analista, com suas propriedades paradoxais de presençaausência - já que representa um objeto histórico, anterior -, sugere também a possibilidade de o setting ser usado como um ambiente facilitador, capaz de contar com as dimensões da ausência, da transicionalidade e da terceiridade, em suma, da metaforização junto a objetos substitutos (Green, 2000).

Nos pacientes que não podem usar o enquadre desta maneira, determinadas questões em torno da destrutividade e da realidade ganham maior relevância, residindo aí a problemática dos ataques ao enquadre. Nos casos-limite, a destrutividade adquire manifestações frequentes, esteja ela dirigida ao trabalho terapêutico e ao analista (Winnicott, 1969 [1968]) ou à própria atividade psíquica (Green, 1988 [1975]); 2000), podendo inclusive ser considerada um indicador importante para se chegar à etiologia destes casos (Green, 1988 [1977]; Garcia \& Damous, 2008). As questões referentes à realidade, por sua vez, se fazem sentir no senso de realidade abalado (Figueiredo, 2003; Coelho Jr. \& Getlinger, 2006) e na dificuldade de diferenciar as realidades interna/externa, separando assim o eu e o outro (Little, 1981 [1958]; Repetto, 1986; André, 1999).

Considerando as dificuldades relacionadas à destrutividade, ao reconhecimento da realidade como externa ao eu e à diferenciação eu-outro, nossa questão é a de pensar que relações a clínica dos casos-limite teriam com as formulações de Winnicott (1969 [1968]) acerca do uso do objeto. Tendo em mente que a conquista do uso leva ao reconhecimento do caráter autônomo do objeto e à consolidação das delimitações dentro-fora via destruição do objeto subjetivo - com a indispensável sobrevivência do ambiente -, perguntamo-nos se os ataques ao enquadre instituiriam tentativas encenadas/atuadas de destruição do objeto subjetivo, na direção do reconhecimento da externalidade, delimitando assim as fronteiras eu-outro de forma mais consistente. Nossa proposta, portanto, é de articular as ressonâncias clínicas da agressividade/destrutividade com os ataques ao enquadre e sua relação com o uso do objeto (Winnicott, 1969 [1968]), considerando ainda os efeitos de um trabalho do negativo malsucedido que redunda numa má separação do objeto primário, característica fundamental dos 
casos-limite que intensifica os aspectos refratários à aplicabilidade do método analítico clássico.

As formulações greenianas acerca do apagamento do objeto primário - via alucinação negativa que instaura a estrutura enquadrante (Green, 2010 [1977]; 1982; 2010 [1988]; 2002) enquanto um espaço potencial interno - adquirem uma dimensão teórico-clínica consistente na medida em que o autor sugere pensar o contexto analítico em referência ao funcionamento mental (Green, 1988 [1975]).

Com um modelo conceitual elaborado a partir do enquadre analítico (Green, 1988 [1977]), a possibilidade de usar o setting como um ambiente facilitador decorre, sobretudo, dos efeitos estruturantes do trabalho do negativo, em que o espaço da ausência instaurado no psiquismo possibilita o deslizamento representacional e o investimento de objetos substitutos, ambos fundamentais à clínica. Em tais condições, o paciente é capaz de associar livremente e investir libidinalmente o analista numa transferência por deslocamento (Roussillon, 2002a), fundada pelo recalque enquanto expressão estruturante do trabalho do negativo. Por outro lado, quando o trabalho do negativo não cumpre sua função primordial de apagamento do objeto primário - prejudicando a instauração do espaço da ausência e a atividade representacional -, entram em cena mecanismos de negação mais radicais, tais como a foraclusão e a clivagem, esta última preponderante nos casos-limite.

Nestes casos, a clivagem se choca com a função continente do enquadre, que busca circunscrever e integrar os diferentes processos psíquicos. Tudo o que o enquadre circunscreve se torna insuportável às “...doenças das fronteiras do ser..." (Figueiredo, 2003a, p. 82), ameaçando ou desperdiçando o esforço feito pela clivagem de manter as partes separadas. Daí redundam as manifestações extrarepresentacionais tais como as toxicomanias, as psicossomatoses, passagens ao ato, condutas perversas, destrutividade direcionada aos processos de pensamento, entre outros (Green, 2010 [1988]), 2000; Figueiredo \& Cintra, 2004). Os fenômenos clínicos extra-representacionais configuram os ataques ao enquadre enquanto expressão de um trabalho do negativo que não cumpriu sua função (Green, 2010 [1988]), sendo assim nomeados por atuarem no caminho contrário à simbolização e à elaboração psíquica, questionando o enquadre e o método analíticos em suas premissas básicas. 
O trabalho do negativo sob sua forma destrutiva na análise se encontra em tudo o que se chama, sem saber sempre do que se fala, de ataques contra o enquadre. Digo sem saber do que se fala porque o que chamam de ataques contra o enquadre se resumem todos eles em uma situação, a do paciente que vos diz: 'Não posso dizer'. (Green, 2010 [1988] : 392)

Quando a clínica é invadida por elementos irrepresentáveis, sobretudo de natureza pré-verbal - quando não há palavras para dizer -, uma atmosfera nebulosa e densa toma conta do contexto analítico, e o setting torna sentida sua presença - sobretudo pelo analista -, como uma pressão interna feita contra seus limites, ameaçando rompê-los a qualquer momento. Diferente de uma análise clássica, em que o paciente "esquece o contexto" (Green, 1988 [1975], p. 50) tão logo estabelece o vínculo transferencial, lançando luz sobre as vicissitudes do processo, na análise dos casos-limite o enquadre é trazido para o primeiro plano, vindo ocupar “...o centro da cena analítica...” (Damous, 2012b, p. 76). Assim, é-se levado a uma análise mais do continente que do conteúdo (Green, 1988 [1975]), como numa troca de posições entre figura e fundo.

Ora, se Green concebe suas formulações metapsicológicas a partir do enquadre, preferindo considerá-lo em referência ao funcionamento mental, na verdade está apontando para a característica comum entre o enquadre e o trabalho do negativo, sobretudo no que tange à instituição de um espaço potencial propício às trocas, sejam elas intrapsíquicas ou intersubjetivas:

Eu me explico: da mesma maneira que um setting analítico que preenche sua função deve se fazer esquecer - o que Donnet chamou de enterramento [ocultação] do setting -, eu diria, da mesma maneira, que o objeto, absolutamente necessário à elaboração da estrutura psíquica, deve se apagar. (Green, 2010 [1988] :301)

Tal como o objeto primário se transforma em estrutura enquadrante ao deixar-se esquecer, o enquadre clínico deve ser também esquecido e assimilado pelo paciente, tornando-se um pano de fundo silencioso (Green, 1988 [1975]; Donnet, 2005a), ao menos na maior parte do tempo. Uma vez assimilado, o enquadre é usado como solo para a emergência dos conflitos intrapsíquicos e das vicissitudes das relações objetais, e o tratamento pode ser levado de acordo com os padrões habituais. 
...Em uma análise clássica, o paciente, após as surpresas do começo, termina por assimilar todos os elementos de uma situação que permite o prosseguimento da análise (entrevistas regulares, duração fixa das sessões, as respectivas posições do divã e da poltrona, limitação da comunicação a um nível verbal, associação livre, o fim da sessão, interrupções regulares, modos de pagamento, etc.). Absorvido na estranheza daquilo que está se passando dentro de si, ele esquece o contexto e logo permite o desenvolvimento da transferência a fim de prender essa estranheza a um objeto. Os elementos do contexto suprem um material para interpretação apenas quando existem modificações eventuais. (Green, 1988 [1975] : 50-51)

Os elementos do setting a serem interpretados, neste caso, condizem com aqueles aos quais Bleger (1967) se referiu como devendo adentrar o processo quando de quebras eventuais do enquadre. Além de tais eventualidades, no entanto, uma análise clássica também se depara com momentos de "dessimbolização" (Donnet, 2005a, p. 29), em que a interpretação deve ser suspensa até que o enquadre possa ser retomado em suas possibilidades simbolizantes. Neste caso, no entanto, o período de "dessimbolização" é geralmente curto, e se algo no tratamento se contrapõe ao enquadre no sentido de questionar seus limites, é sobretudo em função de o enquadre incitar a experiência da transgressão (Green, 1990 [1986a]; Damous, 2012a, 2012b) pelo fato mesmo de instaurar leis e delimitar determinadas fronteiras. Uma diferença, no entanto, deve ser feita entre o não cumprimento eventual de certas regras pelo paciente neurótico e os ataques ao enquadre nos casos-limite, que não adquirem um caráter transgressivo, tratando-se mais de uma busca pelos próprios limites:

\begin{abstract}
...No primeiro caso, mais propício da neurose, os pacientes têm afirmados os seus limites psíquicos e por isso os limites da analisabilidade engendrados na situação analítica podem ser vivenciados sob o viés transgressivo, aberto à elaboração. No segundo caso, muito mais condizente com os pacientes limítrofes, os pacientes buscariam ainda a pertinência dos limites psíquicos não configurados efetivamente, ou constituídos de maneira muito precária, tendendo por isso mesmo a engendrar limites de analisabilidade que parecem antes procurar os próprios limites. (Damous, 2012b : 77-78)
\end{abstract}

Em tais condições, a análise dos casos-limite é conduzida por longo tempo no sentido de possibilitar a constituição dos limites (Donnet, 1999; Damous, 2012a, 2012b), sejam os do paciente, sejam os do enquadre analítico. Deste modo, o analista vê-se às voltas com a questão de instauração do enquadre e das possibilidades de análise (André, 1999), tal como Winnicott (1955-56) trabalhava 
de um modo distinto antes de poder lançar mão da interpretação e retomar, com o mesmo paciente, a análise padrão.

A clínica winnicottiana de alternância entre holding e interpretação condiz com a afirmativa de que os processos de integração, personalização e realização comportam flutuações (Winnicott, 1945), sendo, portanto, tarefas para a vida toda. As conquistas finais do desenvolvimento emocional primitivo, tais como o concern e o uso do objeto, podem ressurgir como tarefas clínicas, sobretudo se tiverem sido prejudicadas em função de condições ambientais adversas. No que concerne ao uso do objeto na clínica, que é “...um dos mais cansativos de todos os primitivos fracassos que nos chegam para posterior reparo" (Winnicott, 1969, p. 125), o analista irá se confrontar com “ataques" (Winnicott, 1969, p. 128) à sua pessoa e à técnica analítica, a análise devendo se voltar mais para questões de sobrevivência do que de interpretação.

Os ataques ao enquadre podem ser considerados como tudo aquilo que, por algum viés destrutivo - direcionado aos próprios processos psíquicos ou à relação intersubjetiva -, extravasa as fronteiras da prática e do método psicanalíticos, neutralizando suas condições de possibilidade e exercício. Nos casos-limite, a prevalência do ato em detrimento da representação (Green, 1988 [1975], 2000; André, 1999, Roussillon, 1999a) intensifica os ataques, por sua vez dirigidos ao analista desde demandas insaciáveis de amor até uma fria indiferença ou intensas manifestações de agressividade (Figueiredo, 2003b; Garcia \& Damous, 2008; Ruggiero, 2012). Tais manifestações, por seguirem a lógica da atuação, inviabilizam o cumprimento da regra fundamental e o objetivo primordial do enquadre de propiciar a simbolização através da palavra.

Além dos efeitos nefastos ao plano representacional e à possibilidade de associar livremente, a clínica psicanalítica nestes casos é questionada em seu motor principal devido à não-instauração de uma neurose de transferência stricto sensu (André, 2002; Figueiredo, 2003c), invocando uma definição em negativo: “...a experiência borderline em psicanálise começa aí onde a neurose de transferência não começa." (André, 2002, p. 76). E o risco disso que nunca começa é que, de igual modo, jamais termine, ou efetue uma interrupção brusca como forma de guardar intocado o analista mais do que dele se separar, de fato.

Pois, se o sujeito se encontra aprisionado na relação com um objeto único (André, 1999) do qual não houve uma separação eficaz, na clínica isto terá 
consequências para a instauração da transferência que, tal como a rede de associações representacionais, pressupõe o deslocamento e a metaforização de seu objeto original:

\begin{abstract}
...A constituição da atividade de representação pressupõe que o psiquismo se desprenda de seu modelo orgânico para tornar-se a metáfora deste; em todo caso, constitui a condição de possibilidade do processo associativo, do deslizamento simbólico de uma representação para outra. É também a condição de possibilidade de transferência analisável: se o analista (talvez mesmo o divã) $e ́$ a mãe - e não a repetição de uma de suas figuras - a distinção da transferência como transferência e, portanto, sua análise, são, no mínimo, contrariadas. (André, 1999 : 76. Grifo do autor.)
\end{abstract}

Correlativamente, a interpretação encontra sérias dificuldades já que, normalmente, ela incide sobre uma situação representativa da situação original que, embora reproduzida e atualizada, só é analisável na medida em que pode ser compreendida em termos de metáfora. Em situações favoráveis, portanto, a interpretação "triangula" (André, 1999, p. 76), introduzindo algo da ordem de um terceiro que pressupõe uma ausência, um desprendimento ou separação. $\mathrm{Na}$ análise dos casos-limite, diferentemente, o trabalho analítico deve ser considerado em grande escala em termos de respostas do objeto/ambiente, tal como o ambiente dos primórdios, o que envolve elementos como constância, confiabilidade, segurança e sobrevivência (Winnicott, 1969 [1968]).

Na visão de Figueiredo (2003b), os ataques podem se dar de forma direta ou indireta, sendo bastante comum, na clínica borderline, a alternância entre as diversas modalidades aí engendradas. Os ataques diretos consistem em manifestações verbais de desvalorização, desprezo, indiferença e desmerecimento para com as regras e condições da análise, incluindo aí tudo o que o analista proporciona e também o “...que ele “é'...” (Figueiredo, 2003b, p. 115). O paciente pode criticar, por exemplo, o tom de voz ou os movimentos corporais do analista, em desaprovações dirigidas diretamente à sua pessoa (Rosenfeld, 1989). Frente às exigências do paciente, o tratamento parece algo inútil diante da grandeza do seu sofrimento ou dos fatos extremados experimentados ao longo da vida, e deste modo o analista e a análise correm o risco de serem relegados ao último plano ou caírem no ostracismo.

Embora expressos de maneira explícita, os ataques diretos não são necessariamente os mais agressivos. Os indiretos, por sua vez, podem ser mais 
violentos já que apontam para as reservas do analista sob forma de "...demandas insaciáveis e exorbitantes de implicação positiva..." (Figueiredo, 2003b, p. 115) e de implicação negativa. Incluem grandes exigências de amor, atenção, maternagem, paternagem, impondo ainda um imperativo de ódio e distanciamento, ameaçando consumir as reservas em termos de disponibilidade interna.

...Seja pelo amor exigente ou pelo ódio impositivo a temperatura do processo é levada ao ponto de ebulição e as reservas do analista, em todas as acepções, ficam, senão torradas, ao menos bastante chamuscadas. (...). É como se o analista fosse ou devesse ser um seio inesgotável ou um saco de pancada absolutamente conformado com essa condição, e também inesgotável na sua capacidade de resistir e suportar agressões. (Figueiredo, 2003b : 115)

Os ataques indiretos dizem respeito, ainda, ao não-uso das reservas do analista, em função de uma idealização que não permite que elas sejam usadas por medo de serem destruídas ou esgotadas (Figueiredo, 2003b). O não-uso já havia sido teorizado por Winnicott (Winnicott, 1968b), ao descrever uma espécie de proteção feita pelo paciente para com o analista, como um objeto “...perfeito e inatingível" (Winnicott, 1968b, p. 182) que ainda não pode ser usado quando, na realidade, é exatamente a mudança para o uso aquilo que o paciente procura (Winnicott, 1968b):

Aqui está o sujeito e lá se acha o objeto, mas na experiência do primeiro, não pode haver uso do segundo. Na prática, o analisando não pode usar o analista, de maneira que a tarefa primordial deste é capacitar aquele a tornar-se capaz de usar, com o corolário de tornar-se capaz de ser usado. (...). Levei em consideração o fato de que, com muitos pacientes, estas questões não são altamente significantes, enquanto que, para outros, é a própria mudança que estava sendo procurada. Como tantas vezes se mostra verdadeiro quando examinamos um mecanismo psicanalítico, trata-se de uma questão de diagnóstico, e, se fôssemos melhores em diagnóstico, pouparíamos a nós mesmos e a nossos pacientes um bocado de tempo e desespero. (Winnicott, 1968b : 182)

O diagnóstico, através da possibilidade de uso/ não-uso da situação analítica, é especialmente útil quando engloba a diferença entre agressão e agressão reativa (Rodulfo, 2009), já que a destrutividade também se expressa como uma busca incipiente pelo uso (Winnicott, 1969 [1968]). Por esta perspectiva, torna-se importante distinguir entre uma destrutividade que pôde adquirir representação na fantasia inconsciente, não se tornando uma ameaça 
social (Winnicott, 1965; Roussillon, 1991) de uma agressividade que se submete à intrusão ambiental, tendo na reação sua única possibilidade de expressão (Winnicott, 1950-55), como é o caso dos pacientes borderline (Garcia \& Damous, 2008).

No primeiro caso, o indivíduo pôde contar com um ambiente suficientemente bom que lhe ofereceu as condições necessárias para poder não só ter a experiência onipotente do "achado-criado", como também a do "destruídoachado" (Roussillon, 2000 [1999]; 2009). A agressividade e a destrutividade se engendram aqui num percurso que vai desde a agressividade primária - vivida necessariamente de forma impiedosa, sem o reconhecimento do objeto em sua natureza externa - até a destruição do objeto subjetivo, no estágio do uso do objeto, em que a sobrevivência do ambiente transcende a onipotência do bebê, e o objeto pode então ser reconhecido em sua natureza externa e autônoma.

Assim, a oposição e a sobrevivência do objeto têm papel fundamental no encontro com a externalidade, já que a agressividade não "desliza" (Roussillon, 2009, p. 1007), tampouco depara-se com o vazio quando da falta de oposição (Lejarraga, 2012). O ambiente, portanto, acusa recepção da agressividade, mas nem por isso sucumbe à destrutividade do bebê. Se, porventura, o ambiente não oferece a oposição necessária ou oferece um "excesso de oposição" (Winnicott, 1950-55, p.303), a agressividade "pega carona" nas reações à intrusão, deixando de ser parte do gesto espontâneo e de descoberta da externalidade, tornando-se, então, agressão reativa (Rodulfo, 2009) e tendência à destruição (Roussillon, 1991). A partir daí, a capacidade para usar objetos ficará comprometida, incidindo sobre o estabelecimento de futuras relações entre pessoas totais.

...Desviada do seu propósito de construção da externalidade, como se dá na saúde, a agressividade não leva à aquisição da capacidade de uso do objeto, mas é consumida na necessidade de reagir. Prisioneiro que está da relação com o objeto subjetivo, o objeto não inaugura a possibilidade de experimentar a realidade compartilhada e permanece refém daquilo que Green $(1986,1988)$ entende como a situação do objeto que não se deixa apagar. (Garcia \& Damous, 2008 : 132)

O borderline, bastante submerso na relação com o objeto subjetivo, tem dificuldades no reconhecimento do caráter independente da externalidade e na diferenciação entre as realidades interna/externa. Somada a uma agressividade não bem manejada pelo ambiente, os investimentos pulsionais às fronteiras egoicas 
são precários, atestando a insuficiência da "função narcisante dos objetos" (Figueiredo, 2003a, p. 89).

Visto que a constituição simultânea das realidades dentro/fora está intimamente relacionada ao investimento às fronteiras internas e externas do eu (Figueiredo, 2003a) ou ao duplo limite (Green, 1982), o senso de realidade encontra-se abalado no borderline (Figueiredo, 2003a, 2003b, 2004; Coelho Jr. \& Getlinger, 2006), levando o sujeito a recorrer a sucessivos testes de realidade na tentativa de discriminar entre realidade e fantasia (Figueiredo, 2004). Na clínica, os testes são geralmente efetuados através de provocações ou confrontos com a realidade, atacando o objeto-analista como forma de alcançar a discriminação entre o eu e o outro, entre realidade interna e realidade externa.

Neste ponto, a função de oposição do analista adquire relevância, já que ele entra em cena como lugar da externalidade/alteridade, que é aquilo que, na verdade, o paciente está buscando inconscientemente (Rodulfo, 2009). Todavia, já que é somente através da intrusão ambiental que o sujeito encontra possibilidades para ser agressivo, ele próprio irá procurar no ambiente determinadas circunstâncias intrusivas e persecutórias a fim de sentir algo que lhe seja real; em última instância, ele próprio se sentir existindo:

\footnotetext{
...Essa agressividade... (...) ...é valiosa para o indivíduo, porque traz consigo a sensação de realidade e a sensação de estar se relacionando. No entanto, ela só existe quando suscitada por uma oposição ou por uma (posterior) perseguição. Faltam-lhe raízes no impulso pessoal motivado pela espontaneidade do ego. (Winnicott, 1950-55 : 304)
}

Neste caso, o indivíduo não se sente real a não ser quando age de modo destrutivo e impiedoso (Winnicott, 1950-55), e deste modo nos perguntamos que funções teriam as expressões destrutivas que emergem na clínica, explicitamente direcionadas à situação analítica, mais precisamente ao objeto-analista. Ora, se o paciente borderline está aprisionado ao objeto subjetivo e a agressividade, quando não bem manejada pelo ambiente, se torna agressão reativa (Rodulfo, 2009) ou “destruição real” (Winnicott, 1969 [1968]), será que os ataques ao enquadre empreenderiam, de forma efetiva e atuada, a tentativa de passagem para o campo do uso do objeto?

Sabemos que foi no contexto clínico de referência borderline que Winnicott (1969 [1968]) construiu sua teoria do uso do objeto, no encontro com 
estes pacientes que "...não conquistaram ainda essa capacidade..." (Lejarraga, 2012, p.60), cujos fenômenos clínicos trazem para primeiro plano o objetivo de ascensão à capacidade de uso do objeto, no caso, o uso do analista:

...Muitos de nossos pacientes chegam-nos com esse problema já solucionado: podem usar objetos, podem usar-nos e podem usar a análise, tal como usaram seus pais, seus irmãos e seus lares. Entretanto, muitos pacientes necessitam adquirir, através de nós, uma capacidade de nos usar. Esta é, para eles, a tarefa analítica. (Winnicott, 1969 [1968] : 130)

Deste modo, é necessário que o analista possa identificar a incapacidade de uso, sendo os ataques destrutivos um indicador indispensável (Winnicott, 1968b; Rodulfo, 2009) à necessidade clínica de desenvolvimento e estabelecimento da capacidade de uso. Neste contexto, o fundamental em termos técnicos é que o analista sobreviva aos ataques efetuados à sua própria pessoa e à situação analítica, já que a interpretação só é aplicável em situações em que o paciente pode contar com um eu estabelecido e capaz de considerar a alteridade como um fato em si (Winnicott, 1954; 1955-56; 1969 [1968]).

Nos ataques ao enquadre efetuados pelo paciente limítrofe, a destruição se torna a característica central do tratamento (Winnicott, 1969 [1968]) e, no entanto, a permanência do sujeito em análise junto à receptividade do analista que não se deixa destruir atesta, em última instância, a busca pelo objeto (Rodulfo, 2009) ou a "...procura de contato primitiva com o objeto-analista" (Figueiredo, 2003a, p. 114). Pois, já que o self é um lugar de encontros, determinadas ações se repetem infinitamente até que possam residir em algum lugar ou "acontecer no mundo" (Safra, 1999, p. 136):

Muitos comportamentos chamados destrutivos assinalam que o indivíduo jamais teve o encontro humano necessitado. São situações em que o ser humano vive em solidão absoluta, em um estado de sofrimento sem fim, pois, nessas áreas de experiências, não há para ele tempo ou espaço. O indivíduo nestas condições faz o possível e o impossível para afetar alguém e inscrever-se no mundo dos homens. (Safra, 1999: 136)

Deste modo, a necessidade de atacar as reservas do analista (Figueiredo, 2003b), violando seus limites (Coelho Jr \& Getlinger, 2006), constitui uma forma de reclamar ao objeto uma receptividade - oposição e sobrevivência - não oferecida pelo objeto primário, instituindo assim a única forma possível de 
empreender “...um encontro que nunca se deu...” (Ruggiero, 2012, p. 602). Nas palavras de Winnicott (1969 [1968]):

...Se for numa análise que isso esteja se realizando, então, o analista, a técnica analítica e o cenário analítico, todos entram como sobrevivendo ou não aos ataques destrutivos do paciente. Essa atividade destrutiva constitui a tentativa, empreendida pelo paciente, de colocar o analista fora da área do controle onipotente, isto é, para fora, no mundo. Sem a experiência da destrutividade máxima (objeto não protegido), o sujeito jamais coloca o analista para fora e, portanto, não pode mais do que experimentar uma espécie de auto-análise, usando o analista como projeção de uma parte do eu (self). (Winnicott, 1969 [1968] : 127)

Num tal contexto, todavia, o analista deve estar atento para não reduzir à relação com a sua pessoa todo e qualquer gesto do paciente que está “...tentando construir uma exterioridade..." (Roussillon, 2002a, p. 16). Se o analista atribuir tudo a si próprio e tentar se apropriar de qualquer coisa ao seu alcance, não fará mais do que repetir a imago de uma mãe narcísica que nunca sai de cena. Por outro lado, os ataques também se deparam com os limites pessoais do analista, e neste aspecto é importante que o paciente possa destruir o analista, mas deixá-lo também sobreviver. Ou seja,...

...que a destrutividade possa se tornar suficientemente fantasmática e potencial, que possa ser jogada sem demasiado perigo efetivo, que possa ser jogada plenamente na esfera que é a sua, a esfera psíquica. (Roussillon, 1991 : 153)

Só assim, através do espaço psíquico potencial é que a agressividade poderá transformar-se em criação no mundo, um mundo de natureza externa e de objetos considerados em sua autonomia para-além da onipotência do sujeito. Deste modo, presumimos que, no atendimento dos casos-limite, mais do que o enquadre/ situação analítica/ setting representar uma relação objetal, ele possibilita o nascimento de uma relação objetal (Green, 1988 [1975]). Nesta penosa dinâmica clínica repleta de ataques, a qualidade do ambiente em termos de sobrevivência é o que dará abertura para o reconhecimento da externalidade e o concomitante trabalho de traçado das fronteiras do eu (André, 1999), tão incertas quanto ruidosas nos casos-limite. Assim, o setting, que não se faz esquecer justamente pelo fato de ser ou poder ser atacado (e sobreviver), é tido como lugar de confiança, esperança e transformação. 


\section{6.}

\section{Considerações finais}

O presente trabalho, embora tenha tratado de um assunto clínico, consistiu numa pesquisa teórica de entrelaçamento entre Green e Winnicott, propondo uma articulação entre a leitura greeniana dos aspectos clínicos e metapsicológicos dos casos-limite e a busca pela conquista do uso do objeto na clínica (Winnicott, 1969 [1968]). A associação entre os dois autores se deu através do que se convencionou chamar de ataques ao enquadre, que ocorrem com bastante frequência nos atendimentos aos casos-limite (Green, 2010 [1988]; André, 1999; Figueiredo, 2003b; Garcia, 2010 [2007]; Damous, 2012a; 2012b), pondo em questão as condições de base do tratamento e a aplicação do método psicanalítico baseado na associação livre do paciente e na escuta flutuante e interpretação do analista (Freud, 1904).

No percurso do trabalho, foi preciso, a princípio, retomar a teoria do desenvolvimento emocional primitivo (Winnicott, 1945) de modo a se chegar até o uso do objeto, etapa final do trajeto de constituição subjetiva e discriminação entre o eu e o não-eu. Foi visto que os processos de integração, personalização e realização constituem as primeiras delimitações entre as realidades interna/externa, partindo da indiferenciação inicial entre o bebê e o ambiente. Progressivamente, o estado de fusão e de dependência absoluta vai dando lugar à dependência relativa, na medida em que o bebê adquire meios de guiar a mãe em suas necessidades, dando-se conta de que as vicissitudes do ambiente não condizem com sua ilusão onipotente de o mundo ser parte de seu próprio corpo ou consistir unicamente numa criação sua. Com o auxílio dos fenômenos transicionais, as ausências não demasiadamente longas do objeto auxiliam as dinâmicas de separação-(re)união, instaurando, ainda, a capacidade de simbolização e representação do objeto quando de sua ausência (Winnicott, 1971a).

$\mathrm{Na}$ infinita tarefa de discriminar as realidades interna/externa, viu-se que a agressividade possui o importante papel de contato com o mundo externo, cuja oposição confere o caráter de realidade às experiências vividas (Winnicott, 195055). Por outro lado, como é o caso dos pacientes borderline, a oposição ineficaz 
redunda em agressividade reativa, capaz de se expressar somente enquanto uma reação à intrusividade do ambiente, tornando-se destruição efetiva e uma ameaça social (Winnicott, 1965; Lejarraga, 2012). O manejo da agressividade não efetuado de maneira suficientemente boa pelo ambiente acaba trazendo sérios prejuízos à capacidade de se relacionar com pessoas totais, trazendo limitações ao uso do objeto, que consiste na destruição do objeto subjetivo e no reconhecimento da natureza externa do objeto. A conquista do uso do objeto só é possível, todavia, se o objeto sobreviver aos ataques destrutivos, atestando sua existência na realidade compartilhada para além da onipotência do bebê, instaurando, concomitantemente, a unidade do self (Winnicott, 1969 [1968]).

Tendo em vista que os casos-limite ainda não alcançaram a capacidade de usar o objeto (Lejarraga, 2012) e que, na clínica, os ataques destrutivos dirigidos ao analista e à técnica analítica configuram a característica principal do tratamento (Winnicott, 1969 [1968]), nossa proposta foi compreender os ataques ao enquadre nestes casos enquanto tentativas atuadas de passagem para o campo do uso do objeto.

Uma vez compreendidas as particularidades do conceito do uso do objeto em Winnicott (1969 [1968]), foi preciso, na sequência, buscar uma descrição dos casos-limite em Green, um autor indispensável para a compreensão clínica e metapsicológica dos sujeitos em questão. Vimos com Green (1990 [1986]) que os casos-limites apresentam uma constituição precária dos limites intrapsíquicos e intersubjetivos - ou o duplo limite (Green, 1982) -, sendo algo que se articula às vicissitudes do objeto e a um trabalho do negativo que não cumpriu sua função (Green, 2010 [1986; 1988]).

O trabalho do negativo tem por objetivo efetuar o apagamento do objeto primário via alucinação negativa, instaurando o espaço da ausência no psiquismo, conhecida também como a estrutura enquadrante (Green, 2002). O objeto, portanto, é assimilado pelo bebê, tornando-se algo como um pano de fundo psíquico, fundamental à representação do objeto e ao investimento de objetos substitutos (Green, 2010 [1986; 1988]). Nos casos-limite, pelo contrário, o objeto não se deixou esquecer - seja pela presença ou pela ausência em demasia -, tornando-se uma presença maciça no psiquismo, logo não representável. Em tais circunstâncias, teve-se de lançar mão da clivagem enquanto o mecanismo negativizante possível para lidar com os efeitos de excesso resultantes da não- 
ausência do objeto. Como resultado clínico do objeto intrusivamente presente ou demasiadamente ausente, o que ocorrem são os reiterados ataques ao enquadre enquanto manifestações extra-representacionais, impedindo o curso do processo em termos de associação livre e interpretação.

Para os casos que não puderam contar com um ambiente propício à instauração dos limites internos e externos do eu - devido ao manejo precário da agressividade e à não sobrevivência do objeto (Winnicott, 1950-55; 1969 [1968]), bem como a um trabalho do negativo malsucedido (Green, 2010 [1986; 1988]) -, a técnica analítica teve de ser repensada em função de uma problemática pautada em questões relativas aos primórdios da vida psíquica, anteriores ao Édipo e à lógica do desejo.

Neste ponto, a noção winnicottiana de setting trouxe-nos a importante contribuição no que tange à regressão à dependência comumente efetuada pelos pacientes falso self - dentre os quais, o borderline -, só possível de ser vivida num ambiente de confiabilidade, continuidade e segurança. Nos momentos regressivos, a técnica interpretativa adquire um caráter intrusivo, devendo ser substituída pelo holding até que se reinstaurem as condições de interpretabilidade (Winnicott, 1954; 1955-56). No caso dos pacientes limítrofes, na busca pela conquista do uso do objeto na clínica, a interpretação poderá ser reutilizada após os momentos críticos em que o analista enquanto objeto subjetivo terá de ser destruído para poder, enfim, ser descoberto em sua externalidade (Winnicott, 1969 [1968]).

No que diz respeito ao setting/ enquadre/ situação analítica, outras contribuições relevantes foram consideradas através dos postulados dos Baranger (1961-62) e Bleger (1967). A situação analítica como campo dinâmico (Baranger, 1961-62) ampliou nossa percepção para a participação do analista nas fantasias e resistências compartilhadas que adornam as condições de base de uma análise, considerando o baluarte enquanto aquilo que o paciente evita trazer para dentro do processo. Por ser constituído nas esferas da onipotência, logo pautado na organização mais primitiva da personalidade, o baluarte traz os maiores ganhos ao tratamento quando sua análise se torna possível. Para Bleger (1967), os elementos mais primitivos da personalidade - de ordem simbiótica - podem ser analisados nos momentos de quebra do enquadre, já que é sobre a estrutura do enquadre que tais elementos são projetados, permanecendo ali abrigados em surdina. Se o 
enquadre é estritamente cumprido pelo paciente e permanece intocado, a organização primitiva da personalidade não terá meios de ser trazida para dentro do processo, fazendo com que a análise nunca alcance os níveis mais profundos almejados num tratamento analítico.

Ora, se o enquadre que se mantém mudo mascara a organização mais primitiva da constituição subjetiva do paciente, o enquadre nos casos-limite, tão barulhento porque demasiadamente atacado poderia ter, então, algo a nos informar acerca da organização interna do paciente e da natureza do objeto com o qual ele se relaciona e para os quais os ataques são dirigidos.

É neste sentido que a última parte do trabalho se empenhou em consolidar, por uma vertente descritiva dos ataques, o argumento de que estes empreenderiam tentativas atuadas de passagem para o campo do uso do objeto, considerando que se destinariam a destruir o objeto subjetivo com o qual o paciente ainda encontrase enredado. Deste modo, através da descrição da clínica dos casos-limites, considerando os aspectos transferenciais enquanto ressonantes da agressividade/destrutividade e do trabalho do negativo que não cumpriu sua função, almejou-se a articulação entre o enquadre que não se faz esquecer e a busca pela conquista do uso do objeto na clínica. Isto num espaço que ainda não pode ser usado em termos de espaço potencial, tal como o objeto que não se deixou apagar não pôde se transformar no espaço potencial interno da estrutura enquadrante (Green, 2002).

Seguindo as diretrizes de Winnicott (1969 [1968]), os ataques destrutivos ao se defrontarem com a sobrevivência do analista levariam, por fim, ao uso do objeto no que tange ao reconhecimento da externalidade e a uma melhor consolidação das fronteiras egoicas. Tal conquista minimizaria as angústias de intrusão e abandono (Green, 1988 [1975]) perante um objeto demasiadamente vinculado à esfera subjetiva dos relacionamentos, possibilitando a capacidade de estabelecer relações com pessoas totais. Tendo em vista que o encontro com o outro é em grande parte subjetivo, ainda assim é preciso o reconhecimento da natureza externa do objeto a fim de o encontro seja, de fato, um encontro na realidade compartilhada. 


\section{Referências bibliográficas}

ABRAM, J. A linguagem de Winnicott. Dicionário das palavras e expressões utilizadas por Donald W. Winnicott. Rio de Janeiro: Revinter, 2000.

ANDRÉ, J. (1999). O objeto único. In: Cadernos de psicanálise da SPCRJ. Rio de Janeiro, v.15, n.18, 1999.

(2002). Transferência borderline. In: REZENDE, M. (org.). Limites. São Paulo: Escuta, 2004.

BARANGER, M. \& W. (1961-62). La situación analítica como campo dinámico. Problemas del campo psicoanalítico. Buenos Aires: Kargieman, 1969.

BARANGER, M. \& W.; MOM, J. (1982). Processo e não-processo no trabalho analítico. In: Revista FEPAL, São Paulo, p.114-131, Set. 2002.

BIRMAN, J. (1989). O valor da psicanálise. In: Agenda de psicanálise. A questão da agenda. Rio de Janeiro: Xanon, 1989.

BLEGER, J. (1967). Psicanálise do enquadramento psicanalítico. Simbiose e ambiguidade. Rio de Janeiro: Francisco Alves, 1977.

BORGES, G.M.; CARDOSO, M.R. A repetição onírica do "terror": limites da representação. In: GARCIA, C.A. \& CARDOSO, M.R. (orgs.). Limites da clínica, clínica dos limites. Rio de Janeiro: Cia de Freud: FAPERJ, 2011.

BREUER, J; FREUD, S. (1893). Sobre o mecanismo psíquico dos fenômenos histéricos: comunicação preliminar. In: Estudos sobre a histeria. Edição Standard Brasileiro das Obras Psicológicas Completas de Sigmund Freud, vol. II. Rio de Janeiro: Imago, 1996.

BREUER, J; FREUD, S. (1895). Estudos sobre a histeria. Edição Standard Brasileiro das Obras Psicológicas Completas de Sigmund Freud, vol. II. Rio de Janeiro: Imago, 1996.

CANDI, T. S. O que está em jogo no trabalho analítico? As contribuições de André Green para a metapsicologia da situação analítica. In: Revista Brasileira de Psicanálise, v.44, n.2, p. 111-119, 2010.

CARDOSO, M.R. (2005). A servidão ao "outro" nos estados limites. In: CARDOSO, M. R. \& GARCIA, C. A. Entre o eu e o outro. Espaços fronteiriços. Curitiba: Juruá, 2010.

(2007). A impossível "perda" do outro nos estados limites: explorando as noções de limite e alteridade. In: CARDOSO, M. R. \& GARCIA, C. A. Entre o eu e o outro. Espaços fronteiriços. Curitiba: Juruá, 2010.

CARDOSO, M.R. \& MONTEIRO, R.G. Construções e figurabilidade em análise: vias de abertura à representação? IN: MARRACCINI et al. Limites de Eros. 1 ${ }^{\mathrm{a}}$. Ed. São Paulo: Primavera Editorial, 2012. 
CELES, L.A.M. (2006). Entre repetição e abstinência: a pessoalidade do analista em análise. Trabalho apresentado no II Congresso Internacional de Psicopatologia Fundamental e VIII Congresso Brasileiro de Psicopatologia Fundamental. Belém, Setembro de 2006.

(2007). "Dora" contemporânea - e a crise terapêutica da psicanálise. Psicologia Clínica, v. 19, n. 1, p. 137-154. Rio de Janeiro, 2007.

CELES, L.A.M \& GARCIA, C.A. Limites da interpretação. In: GARCIA, C.A. \& CARDOSO, M.R. (orgs.). Limites da clínica, clínica dos limites. Rio de Janeiro: Cia de Freud: FAPERJ, 2011.

CHABERT, C. (1999). Les fonctionnements limites: quelles limites? In: André, J. e col. Les états limites. Paris: PUF.

COUTINHO, A. (1989). A questão do dinheiro em psicanálise. In: Agenda de psicanálise. A questão da agenda. Rio de Janeiro: Xanon, 1989.

DAMOUS, I. Os casos-limite e as falhas ambientais precoces. Dissertação de mestrado. Rio de Janeiro: PUC-Rio, Departamento de Psicologia, 2006.

(2012a). Depressão e lógica do desespero na contemporaneidade: uma visão psicanalítica. Curitiba: Juruá, 2012. (2012b). As psicopatologias limítrofes e o enquadre em questão. In: Rabisco Revista de Psicanálise, Porto Alegre, v.2, n.1, p.73-79. Maio 2012.

DAVIS, M. \& WALLBRIDGE, D. Limite e espaço. Rio de Janeiro: Imago, 1982.

DEUTSCH, H. Some forms os emotional disturbance and their relationship to schizophrenia. The Psychoanalytic Quarterly, v. 11, 301-321, 1942.

DIAS, E. O. Sobre a confiabilidade e outros estudos. São Paulo: D.W.W. Editorial, 2011.

A teoria do amadurecimento de D. W. Winnicott - $2^{\mathrm{a}}$ ed. São Paulo: D.W.W. Editorial, 2012.

DONNET, J.L. (1973) Le divan bien temperé. Le divan bien temperé. Paris: PUF, 2005.

(1999). Patients limites, situations limites. In: André, J. e col. Les états limites. Paris: PUF.

. (2005a). Présentation. Le site analytique et la situations analysante. Le divan bien tempéré. Paris: PUF, 2005.

DUPARC, F. André Green. São Paulo: Via Lettera Editora e Livraria, 2000.

FERENCZI, S. (1928). Elasticidade da técnica. Obras Completas, vol. IV. São Paulo: Ed. WMF Martins Fontes, 2011.

FIGUEIREDO, L. C. (2003). Psicanálise. Elementos para a clínica contemporânea. São Paulo: Escuta, 2003. 
(2003a). AO caso-limite e as sabotangens do prazer.

Psicanálise. Elementos para a clínica contemporânea. São Paulo: Escuta, 2003.

(2003b). A clínica borderline (2000-2001). Psicanálise. Elementos para a clínica contemporânea. São Paulo: Escuta, 2003.

(2003c). Transferência, contratransferência e outras coisinhas mais, ou a chamada pulsão de morte. Psicanálise. Elementos para a clínica contemporânea. São Paulo: Escuta, 2003.

(2004). Os casos-limite: senso, teste e processamento de realidade. Revista Brasileira de Psicanálise, v.38, n.3, 503-519, 2004.

Presença, implicação e reserva. In: FIGUEIREDO, L.C. \& COELHO Jr, N. Ética e técnica em psicanálise. 2 ed. ampliada. São Paulo: Escuta, 2008.

(2011). A situação analisante e a variedade da clínica contemporânea. Revista Brasileira de Psicanálise, v. 45, n. 1, p. 137-149, 2011.

FIGUEIREDO, L. C. M.; CINTRA, E. M. U. Lendo André Green: o trabalho do negativo e o paciente limite. In: CARDOSO, M. R. (org.). Limites. Rio de Janeiro: Escuta, 2004. p. 13-58.

FREUD, S. (1900). A interpretação de sonhos (parte II). Edição Standard Brasileiro das Obras Psicológicas Completas de Sigmund Freud, vol. V. Rio de Janeiro: Imago, 1996.

. (1904) O método psicanalítico de Freud. Edição Standard Brasileiro das Obras Psicológicas Completas de Sigmund Freud, vol. VII. Rio de Janeiro: Imago, 1996.

(1905 [1904]). Sobre a psicoterapia. Edição Standard Brasileiro das Obras Psicológicas Completas de Sigmund Freud, vol. VII. Rio de Janeiro: Imago, 1996.

(1905). Três ensaios sobre a teoria da sexualidade. Edição Standard Brasileiro das Obras Psicológicas Completas de Sigmund Freud, vol. VII. Rio de Janeiro: Imago, 1996.

(1911). O manejo da interpretação de sonhos na psicanálise. Edição Standard Brasileiro das Obras Psicológicas Completas de Sigmund Freud, vol. XII. Rio de Janeiro: Imago, 1996.

(1912a). Recomendações aos médicos que exercem a psicanálise. Edição Standard Brasileiro das Obras Psicológicas Completas de Sigmund Freud, vol. XII. Rio de Janeiro: Imago, 1996.

(1912b). A dinâmica da transferência. Edição Standard Brasileiro das Obras Psicológicas Completas de Sigmund Freud, vol. XII. Rio de Janeiro: Imago, 1996. 
(1913) Sobre o início do tratamento (Novas recomendações sobre a técnica da psicanálise I). Edição Standard Brasileiro das Obras Psicológicas Completas de Sigmund Freud, vol. XII. Rio de Janeiro: Imago, 1996.

(1914a). Recordar, repetir e elaborar. Edição Standard Brasileiro das Obras Psicológicas Completas de Sigmund Freud, vol. XII. Rio de Janeiro: Imago, 1996.

(1914b). Sobre o narcisismo: uma introdução. Edição Standard Brasileiro das Obras Psicológicas Completas de Sigmund Freud, vol. XIV. Rio de Janeiro: Imago, 1996.

(1914c). A história do movimento psicanalítico. Edição Standard Brasileiro das Obras Psicológicas Completas de Sigmund Freud, vol. XIV. Rio de Janeiro: Imago, 1996.

(1915 [1914]). Observações sobre o amor transferencial (Novas recomendações sobre a técnica da psicanálise III). Edição Standard Brasileiro das Obras Psicológicas Completas de Sigmund Freud, vol. XII. Rio de Janeiro: Imago, 1996.

(1915). Os instintos e suas vicissitudes. Edição Standard Brasileiro das Obras Psicológicas Completas de Sigmund Freud, vol. XIV. Rio de Janeiro: Imago, 1996.

(1916-17a). Conferência XXVII. Transferência. In: Conferências introdutórias sobre psicanálise parte III. Teoria geral das neuroses. Edição Standard Brasileiro das Obras Psicológicas Completas de Sigmund Freud, vol. XVI. Rio de Janeiro: Imago, 1996.

(1916-17b). Conferência XXVII. Terapia analítica. In: Conferências introdutórias sobre psicanálise parte III. Teoria geral das neuroses. Edição Standard Brasileiro das Obras Psicológicas Completas de Sigmund Freud, vol. XVI. Rio de Janeiro: Imago, 1996.

------------. (1920). Além do princípio de prazer. Obras psicológicas de Sigmund Freud. Escritos sobre a Psicologia do inconsciente, vol. 2. Rio de Janeiro: Imago Ed., 2006.

(1923). O Eu e o Id. Obras psicológicas de Sigmund Freud. Escritos sobre a Psicologia do inconsciente, vol. 3. Rio de Janeiro: Imago Ed., 2007.

(1924). O problema econômico do masoquismo. Obras psicológicas de Sigmund Freud. Escritos sobre a Psicologia do inconsciente, vol. 2. Rio de Janeiro: Imago Ed., 2006.

(1925). A negativa. Obras psicológicas de Sigmund Freud. Escritos sobre a Psicologia do inconsciente, vol. 3. Rio de Janeiro: Imago Ed., 2007.

(1926). Inibições, sintomas e ansiedade. Edição Standard Brasileiro das Obras Psicológicas Completas de Sigmund Freud, vol. XX. Rio de Janeiro: Imago, 1996. 
(1937). Construções em análise. Edição Standard Brasileiro das Obras Psicológicas Completas de Sigmund Freud, vol. XXIII. Rio de Janeiro: Imago, 1996.

(1940 [1938a]). A cisão do eu no processo de defesa. Obras psicológicas de Sigmund Freud. Escritos sobre a Psicologia do inconsciente, vol. 3. Rio de Janeiro: Imago Ed., 2007.

(1940 [1938b]). Esboço de psicanálise. Edição Standard Brasileiro das Obras Psicológicas Completas de Sigmund Freud, vol. XXIII. Rio de Janeiro: Imago, 1996.

GARCIA, C. A. (2005). Trauma e narcisismo negativo: questões para a clínica contemporânea. In: CARDOSO, M. R. \& GARCIA, C. A. Entre o eu e o outro. Espaços fronteiriços. Curitiba: Juruá, 2010.

. (2007). Os estados limites e o trabalho do negativo: uma contribuição de A. Green para a clínica contemporânea. In: CARDOSO, M. R. \& GARCIA, C. A. Entre o eu e o outro. Espaços fronteiriços. Curitiba: Juruá, 2010.

(2009). Continuidade e ruptura no processo de constituição psíquica. In: CARDOSO, M. R. \& GARCIA, C. A. Entre o eu e o outro. Espaços fronteiriços. Curitiba: Juruá, 2010.

GARCIA, C; DAMOUS, I. (2008). A agressividade no contexto dos cuidados primários: a liberdade suficientemente boa. IN: Cadernos de Psicanálise SPCRJ. Rio de Janeiro: SPCRJ, v. 24, n.27, p. 119-139, 2008.

GREEN, A. (1975). O analista, a simbolização e a ausência no contexto analítico. Sobre a loucura pessoal. Rio de Janeiro: Imago, 1988.

(1975). L'analyste, la symbolisation et l'absence dans le cadre analytique. La folie privée. Paris: Éditions Gallimard, 1990.

Gallimard, 1990.

(1976). Le concept de limite. La folie privée. Paris: Éditions

(1988 [1977]). O conceito do fronteiriço. Sobre a loucura pessoal. Rio de Janeiro: Imago, 1988.

Gallimard, 1990.

(1979). Le silence du psychanalyste. La folie privée. Éditions (1982). La double limite. La folie privée. Paris: Éditions Gallimard, 1990.

Narcisismo de vida, narcisismo de morte. São Paulo: Editora Escuta, 1988.

La folie privée. Paris: Éditions Gallimard, 1990.

-------------. (1990 [1986a]). 1ª Conferência: "conceituações e limites". Conferências brasileiras de André Green. Metapsicologia dos limites. Rio de Janeiro: Imago, 1990. 
(1990 [1986b]). 2a Conferência: "teoria das representações (coisas e palavras)". Conferências brasileiras de André Green. Metapsicologia dos limites. Rio de Janeiro: Imago, 1990.

(1999). Genèse et situation des états limites. In: André, J. e col. Les états limites. Paris: PUF.

Idées directrices pour une psychanalyse contemporaine. Paris: PUF, 2002.

(2008 [1995]). Préface. L'ancien et le nouveau. In: ROUSSILLON, R. Logiques et archéologiques du cadre psychanalytique. Paris: PUF, 1995.

(2010 [1977]). Anexo 2. A alucinação negativa. O trabalho do negativo. Porto Alegre: Artmed, 2010.

(2010 [1986]). Anexo 1. O trabalho do negativo. O trabalho do negativo. Porto Alegre: Artmed, 2010.

(2010 [1988]). Anexo 3. Seminário sobre o trabalho do negativo. $O$ trabalho do negativo. Porto Alegre: Artmed, 2010.

GURFINKEL, D. Sonhar, dormir e psicanalisar: viagens ao informe. São Paulo: Escuta, 2008.

GUTTIERES-GREEN, L. Variations du cadre et modalités du transfert au cours de patients non névrotiques. In: GREEN, A.; COBLENCE, F. (orgs.). Les voies nouvelles de la thérapeutique psychanalytique: le dedans et le dehors. Paris: PUF, 2006.

HISADA, S. Clínica do setting em Winnicott. Rio de Janeiro: Livraria e Editora Revinter Ltda., 2002.

JANUÁRIO, L. M. \& TAFURI, M. I. A relação transferencial para além da interpretação: reflexões a partir da teoria de Winnicott. Ágora (Rio de Janeiro), v. XIV, n. 2, jul-dez 2011, p. 259-274.

KERNBERG, O. Borderline personality organization. JAPA, v. 15, 641-685, 1967.

KHAN, M. (1962). Psicologia do sonho e a evolução da situação psicanalítica. Psicanálise: teoria, técnica e casos clínicos. Rio de Janeiro: Francisco Alves, 1977.

LAGACHE, D. A transferência. São Paulo: Martins Fontes, 1990.

LAPLANCHE, J.; PONTALIS, J.B. (1982). Vocabulário da psicanálise. 4a ed. São Paulo: Martins Fontes, 2001.

LEJARRAGA, A. L. O amor em Winnicott. Rio de Janeiro: Garamond, 2012.

LEIVI, B. M. Para uma psicanálise do processo psicanalítico. Enquadre, processo e não-processo. Revista FEPAL, São Paulo, p.138-147, Set. 2002. 
LEWIN, B. Dream Psychology and the analytic situation. The Psychoanalytic Quarterly, New York, v.24, p.169-199, 1955.

LITTLE, M. (1990). Ansiedades psicóticas e prevenção. Registro pessoal de uma análise com Winnicott. Rio de Janeiro, Imago Ed., 1992.

MEZAN, R. Freud: a trama dos conceitos. São Paulo: Perspectiva, 2006.

OLIVEIRA, F. G. Do amadurecimento ao encontro analítico: um percurso clínico pela obra de Winnicott. Dissertação de Mestrado. Rio de Janeiro: PUC, Departamento de Psicologia, 2012.

PEREIRA, M.E.C. A introdução do conceito de "estados-limítrofes" em psicanálise: o artigo de A. Stern sobre "the borderline group of neuroses". Revista Latinoamericana de Psicopatologia Fundamental, v. 2, n. 2, p. 159-176, 1999.

PHILLIPS, A. (1988) Winnicott. Aparecida, SP: Idéias \& Letras, 2006.

ROCABERT, J. V. Facilitadores e inibidores do processo analítico: as contribuições de Bleger, e dos Baranger e Mom sobre os conceitos de enquadre, campo analítico, e processo e não-processo em psicanálise. Revista FEPAL. São Paulo, p.132-137, Set. 2002.

RODULFO, R. Trabajos de la lectura, lecturas de la violencia: lo creativo - lo destructivo en el pensamiento de Winnicott $-1^{\mathrm{a}}$ Ed - Buenos Aires: Paidós, 2009.

ROSA, M. A psicose ordinária e os fenômenos do corpo. Revista Latinoamericana de Psicopatologia Fundamental, v. 12, n. 1, p. 116-129, São Paulo, Março 2009.

ROSENFELD, H. A psicose de transferência no paciente fronteiriço. Revista Brasileira de Psicanálise, vol. 23, n. 3, p. 135-152, 1989.

ROUSSILLON, R. (1991). O paradoxo da destrutividade ou a utilização do objeto segundo Winnicott. Paradoxos e situações limites da psicanálise. São Leopoldo, RS: Editora Unisinos, 2006.

ROUSSILLON, R. Agonie, clivage et symbolisation. Paris: PUF, 1999.

(1999a). Traumatisme primaire, clivage et liaisons primaires non symboliques. Agonie, clivage et symbolisation. Paris: PUF, 1999.

(1999b). Violence et culpabilité primaire. Agonie, clivage et symbolisation. Paris: PUF, 1999.

(2000 [1999]). A atualidade de Winnicott. In: Trieb, n.9, 2000, p. 55-71. Rio de Janeiro: Sociedade Brasileira de Psicanálise do Rio de Janeiro.

Paris: PUF, 2008.

Logiques et archéologiqu-es du cadre psychanalytique.

(2008 [1995a]). Le temps freudien du cadre. Logiques et archéologiqu-es du cadre psychanalytique. Paris: PUF, 2008. 
(2008 [1995b]). Les raisons du cadre. Logiques et archéologiques du cadre psychanalytique. Paris: PUF, 2008.

La destructivité et les formes complexes de la "survivance" de l'objet. Revue française de psychanalyse, n.4, vol. 73. PUF, p. 1005 - 1022, 2009.

RUGGIERO, I. The unreacheable object? Difficulties and paradoxes in the analytical relationship with borderline patients. International Journal of Psychoanalysis, v. 93, p. 595-606, 2012.

SAFRA, G. Momentos mutativos em psicanálise. São Paulo: Casa do Psicólogo, 1995.

A face estética do self: teoria e clínica. São Paulo: Unimarco Editora, 1999.

STERN, A. (1938) Investigação psicanalítica e terapia do grupo de neuroses limítrofes. Revista Latinoamericana de Psicopatologia Fundamental, v. 2, n. 2, p. 159-176, 1999.

URRIBARRI, F. Postface. Passion clinique, pensée complexe. In: GRREN, A. Illusions et disillusions du travail psychanalytique. Paris: Odile Jacob, 2010.

WINNICOTT, D. W. (1939). Agressão. Privação e delinquência. $4^{\mathrm{a}}$ Ed. São Paulo: Martins Fontes, 2005.

(1945). Desenvolvimento emocional primitivo. $D a$ pediatria à psicanálise. Obras escolhidas. Rio de Janeiro: Imago Ed., 2000.

(1950-55). A agressividade em relação ao desenvolvimento emocional. Da pediatria à psicanálise. Rio de Janeiro: Imago Ed., 2000.

(1952a). Ansiedade associada à insegurança. Da pediatria à psicanálise. Obras escolhidas. Rio de Janeiro: Imago Ed., 2000.

(1952b). Psicoses e cuidados maternos. Da pediatria à psicanálise. Obras escolhidas. Rio de Janeiro: Imago Ed., 2000.

(1954). Aspectos clínicos e metapsicológicos da regressão no contexto analítico. Da pediatria à psicanálise. Rio de Janeiro: Imago Ed., 2000.

(1954-5). A posição depressiva no desenvolvimento emocional normal. Da pediatria à psicanálise. Rio de Janeiro: Imago Ed., 2000.

(1955-56). Formas clínicas da transferência. $D a$ pediatria à psicanálise. Rio de Janeiro: Imago Ed., 2000.

(1956). A preocupação materna primária. Da pediatria à psicanálise. Obras escolhidas. Rio de Janeiro: Imago Ed., 2000. 
(1957). Sobre a contribuição da observação direta da criança para a psicanálise. O ambiente e os processos de maturação. Porto Alegre: Artmed, 1983.

(1958). A capacidade para estar só. O ambiente e os processos de maturação. Porto Alegre: Artmed, 1983.

(1959). O destino do objeto transicional. Explorações psicanalíticas. Porto Alegre: Artmed, 2005.

(1959-64). Classificação: existe uma contribuição psicanalítica à classificação psiquiátrica? $O$ ambiente $e$ os processos de maturação. Porto Alegre: Artmed, 1983.

(1960a). Teoria do relacionamento paterno-infantil. $O$ ambiente e os processos de maturação. Porto Alegre: Artmed, 1983.

(1960b). Distorção do ego em termos de falso e verdadeiro "self". O ambiente e os processos de maturação. Porto Alegre: Artmed, 1983.

(1961). Observações adicionais sobre a teoria do relacionamento parento-filial. Explorações psicanalíticas. Porto Alegre: Artmed, 2005.

(1962). A integração do ego no desenvolvimento da criança. O ambiente e os processos de maturação. Porto Alegre: Artmed, 1983.

. (1963a). Da dependência à independência no desenvolvimento do indivíduo. $O$ ambiente e os processos de maturação. Porto Alegre: Artmed, 1983.

(1963b). Os doentes mentais na prática clínica. $O$ ambiente e os processos de maturação. Porto Alegre: Artmed, 1983.

Explorações psicanalíticas. Porto Alegre: Artmed, 2005.

(1963d). Distúrbios psiquiátricos e processos de maturação infantil. $O$ ambiente e os processos de maturação. Porto Alegre: Artmed, 1983.

(1963e). Comunicação e falta de comunicação levando ao estudo de certos opostos. O ambiente e os processos de maturação. Porto Alegre: Artmed, 1983.

(1964a). Raízes da agressão. Privação e delinquência. $4^{\mathrm{a}}$ Ed. São Paulo: Martins Fontes, 2005.

(1964b). A importância do setting no encontro com a regressão na psicanálise. Explorações psicanalíticas. Porto Alegre: Artmed, 2005.

(1965). Notas escritas no trem, parte 2. In: Sobre "o uso de um objeto". Explorações psicanalíticas. Porto Alegre: Artmed, 2005. 
(1967). A localização da experiência cultural. O brincar e a realidade. Rio de Janeiro: Imago, 1971.

(1968a). Comentários sobre meu artigo o uso de um objeto. In: Sobre "o uso de um objeto". Explorações psicanalíticas. Porto Alegre: Artmed, 2005.

(1968b). O uso da palavra uso. In: Sobre "o uso de um objeto". Explorações psicanalíticas. Porto Alegre: Artmed, 2005.

(1969 [1968]). O uso de um objeto e relacionamento através de identificações. O brincar e a realidade. Rio de Janeiro: Imago, 1971.

(1971a). Objetos e fenômenos transicionais. O brincar $e$ a realidade. Rio de Janeiro: Imago, 1971.

(1971b). A criatividade e suas origens. O brincar e a realidade. Rio de Janeiro: Imago, 1971.

Natureza Humana. Rio de Janeiro: Imago Ed., 1990. 